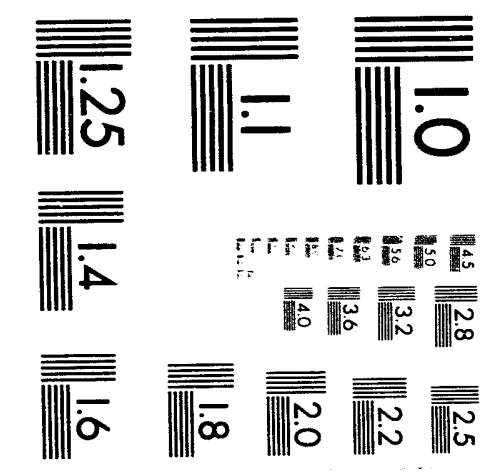



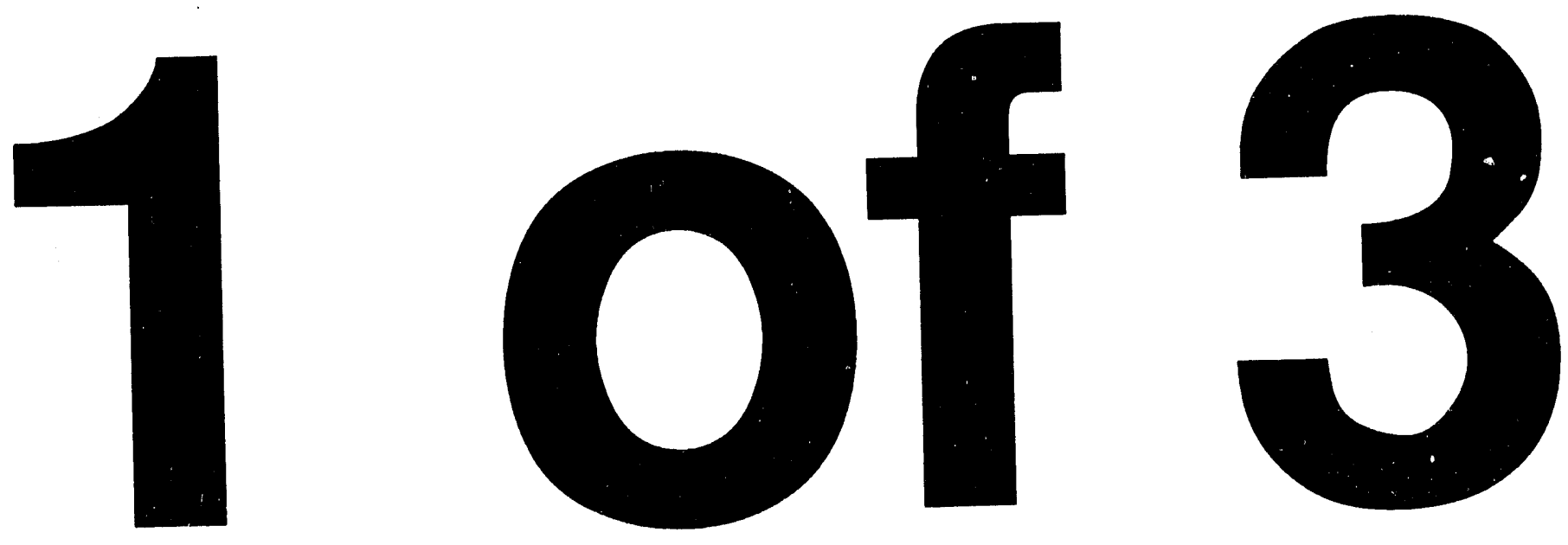


\title{
Ecological Risk Assessment Guidance for Preparation of Remedial Investigation/Feasibility Study Work Plans
}

\section{DRAFT: DO NOT CITE}

\author{
By \\ E.D.Pentecost \\ W.S.Vinikour \\ Prepared for: \\ U.S. Department of Energy \\ Office of Environmental Guidance \\ RCRA/CERCLA Division \\ Washington, DC 20585 \\ Operated by The University of Chicago \\ under ContractW-31-109-Eng-38 \\ Prepared by: \\ Environmental Assessment and \\ Information Sciences Division \\ Argonne National Laboratory
}

August 1993

\section{MASTER}

OISTRIBUTION OF THIS OOCUMENT IS INMLIMITEU

dka 


\section{ACKNOWLEDGMENTS}

We wish to express special appreciation to reviewers of earlier drafts of the document who provided valuable comments and suggestions on scope and content related to ecological risk and assesisment and work plan development. In particular, we would like to thank Thomas Traceski and John Bascietto, U.S. Department of Energy (DOE) Office of Environmental Guidance; Thor Hlohowskyj, John Krummel, and Kirk LaGory of Argonne National Laboratory; and several anonymous reviewers who supplied comments to the DOE Office of Environmental Guidance. Special thanks is due to James Vercellone of Argonne for preparation of figures and module diagrams. Questions concerning document content or use should be directed to John Bascietto, DOE, EH-231 at (202) 586-7917. 
Draft: August 1993

\section{CONTENTS}

PART I: OVERVIEW AND PROCESS DESCRIPTION $\ldots \ldots \ldots \ldots \ldots \ldots \ldots$ I-1

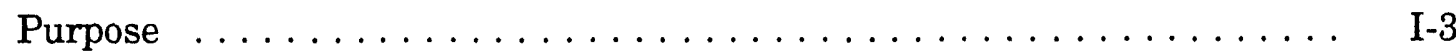

Description of the Ecological Risk Assessment Process . . . . . . . . . I-4

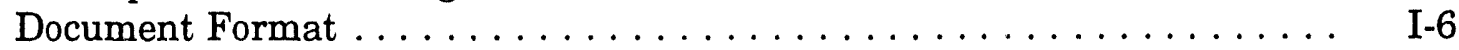

Key to the Graphic Approach $\ldots \ldots \ldots \ldots \ldots \ldots \ldots \ldots \ldots \ldots$ I-10

PART II: MODULE DESCRIPTIONS $\ldots \ldots \ldots \ldots \ldots \ldots \ldots \ldots \ldots \ldots \ldots$ II-1

Chapter 1: Project Planning . . . . . . . . . . . . . . . . II-3

Module 1: Statutory and Regulatory Guidance

Mandates ................... II-7

Module 2: Role of EPA and Other Regulators . . . . . . . . II-13

Module 3: Preliminary Hazardous Substance

Characterization ................. II-17

Chapter 2: Scoping $\ldots \ldots \ldots \ldots \ldots \ldots \ldots \ldots \ldots \ldots \ldots \ldots \ldots$ II-21

Module 4: Existing Site Information $\ldots \ldots \ldots \ldots \ldots \ldots$ II-25

Module 5: Ecological Input for RI/FS Scoping . . . . . . . . II-29

Module 6: Develop Site Ecological Conceptual Model . . . . . . II II-33

Chapter 3: Initial Evaluation . . . . . . . . . . . . . . . . II-39

Module 7: Site Physical Features . . . . . . . . . . II-43

Module 8: Potential Contaminant Pathways in

Ecosystem . . . . . . . . . . . . . . II-47

Chapter 4: Work Plan Rationale . . . . . . . . . . . . . . . II-51

Module 9: Data Needs for Ecological Risk Assessment . . . . . . II-55

Module 10: Work Plan Approach . . . . . . . . . . . . II-63

Chapter 5: RI/FS Tasks . . . . . . . . . . . . . . . . II-69

Module 11: Determination of Assessment and

Measurement Endpoints .............. II-73

Module 12: Ecological Data Evaluation Needs . . . . . . . . . II-79

Module 13: Ecological Field Sampling Plan . . . . . . . . . II-83

Module 14: Ecological Input to Quality Assurance

Project Plan $\ldots \ldots \ldots \ldots \ldots \ldots \ldots \ldots$ II -87

Chapter 6: Alternatives Evaluation . . . . . . . . . . . . . . II II-93

Module 15: Ecological Input to Baseline Risk

Assessment . . . . . . . . . . . . . . . . . . II

Module 16: Ecological Data Analysis for Comparison of

Remedial Action Alternatives . . . . . . . . . . . II-101

Chapter 7: References ........................ II-105 


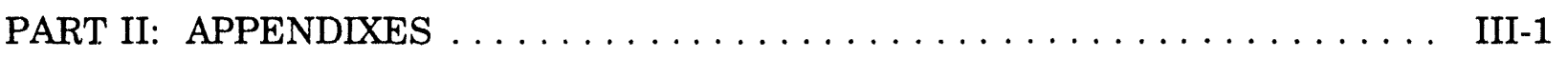

APPENDIX A: Example of an Ecological Assessment Work Plan $\ldots \ldots$ III-7

APPENDIX B: Ecological Field Sampling Plan Annotated Outline . . . . . III-55

APPENDIX C: Ecological Quality Assurance Project Plan

Annotated Outline . . . . . . . . . . . . . . . . . III-63

APPENDIX D: Sensitive Environments Rating Values $\ldots \ldots \ldots \ldots \ldots$ III-77

APPENDIX E: U.S. Environmental Protection Agency Regional Biological Technical Assistance Group Coordinators/Contacts . . . . . . III-83

APPENDIX F: Glossary $\ldots \ldots \ldots \ldots \ldots \ldots \ldots \ldots \ldots \ldots \ldots \ldots \ldots \ldots \ldots$ III-87

\section{TABLES}

1.1 Examples of Applicable or Relevant and Appropriate Requirements . . . . . . II-10

5.1 Standard Tasks Required for the Preparation of an RI/FS Work Plan ...... II-72

A.1 Contaminants of Potential Concern at the Washbone Site . . . . . . . . . III-14

A.2 Potential Ecological Receptor Groups for the Washbone Site

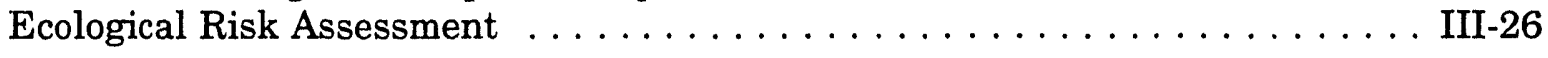

D.1 Sensitive Environments Rating Values $\ldots \ldots \ldots \ldots \ldots \ldots \ldots \ldots$ III-80

\section{FIGURES}

1.1 Overview of the RI/FS Process (modified from EPA 1988a) $\ldots \ldots \ldots \ldots \ldots$ I-7

1.2 Planning and Scoping Stages in RJ/FS Planning $\ldots \ldots \ldots \ldots \ldots \ldots$ I-8

1.3 Work Plan Development and Implementation Stages in RI/FS Planning . ... I-9

1.4 Explanation of Flowchart Symbols $\ldots \ldots \ldots \ldots \ldots \ldots \ldots \ldots \ldots \ldots \ldots \ldots \ldots \ldots \ldots$

6.1 Example of a Conceptual Site Ecological Model ................ II-37 
Draft: August 1993

\section{FIGURES (Cont.)}

A.1 Location of the Washbone Site $\ldots \ldots \ldots \ldots \ldots \ldots \ldots \ldots \ldots \ldots$ III-12

A.2 Staged Approach Proposed for the Washbone Site Ecological

Risk Assessment . . . . . . . . . . . . . . . . . . . . . . III-22

A.3 Proposed Ecological Sampling Locations at the Washbone Site . . . . . . . . III-30 
Draft: August 1993
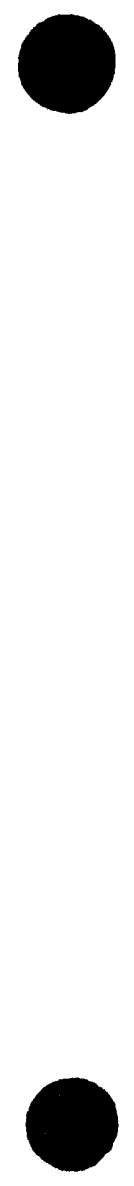


\section{NOTATION}

ARAR applicable or relevant and appropriate requirement

BTAG Biological Technical Assistance Group

CERCLA Comprehensive Environmental Response, Compensation, and Liability Act of 1980

DOE U. S. Department of Energy

EPA U. S. Environmental Protection Agency

ERPM environmental restoration program manager (DOE)

FFA Federal Facility Agreement

FS feasibility study

FWS U. S. Fish and Wildlife Service

NCP National Contingency Plan

NEPA National Environmental Policy Act

NPL National Priorities List

NRDA natural resource damage assessment

ORNL Oak Ridge National Laboratory

OSC on-site coordinator

QA quality assurance

QAPP quality assurance project plan

QA/QC quality assurance/quality control

$\operatorname{PCB}(\mathrm{s}) \quad$ polychlorinated biphenyl(s)

RAGS II Risk Assessment Guidance for Superfund, Volume II Environmental Evaluation Manual

RCRA Resource Conservation and Recovery Act of 1976

RI remedial investigation 
Draft: August 1993

RI/FS remedial investigation/feasibility study

SAP sampling and analysis plan

SARA Superfund Amendments and Reauthorization Act of 1986 
PART I: OVERVIEW AND PROCESS DESCRIPTION 


\section{PURPOSE}

This guidance document (1) provides instructions on preparing the components of an ecological work plan to complement the overall site remedial investigation/feasibility study (RI/FS) work plan and (2) directs the user on how to implement ecological tasks identified in the plan. Under the Comprehensive Environmental Response, Compensation, and Liability Act of 1980 (CERCLA), as amended by the Superfund Amendments and Reauthorization Act of 1986 (SARA), an RI/FS work plan will have to be developed as part of the site-remediation scoping

Ecological work plans must identify the procedures to be used for an ecological assessment at a particular site and describe the rationale and objectives for ecological data acquisition at the site. Details for collection, analysis, and quality assurance of ecological data are to be described in a sampling and analysis plan. Guidance on developing these plans is presented in Part II of the document.

process. Specific guidance on the RI/FS process and the preparation of work plans has been developed by the U.S. Environmental Protection Agency (EPA 1988a). This document provides guidance to U.S. Department of Energy (DOE) staff and contractor personnel for incorporation of ecological information into environmental remediation planning and decision making at CERCLA sites. An overview analysis of early ecological risk assessment methods (i.e., in the 1980s) at Superfund sites was conducted by the EPA (1989a). That review provided a perspective of attention given to ecological issues in some of the first RI/FS studies. By itself, that reference is of somewhat limited value; it does, however, establish a basis for comparison of past practices in ecological risk with current, more refined methods.

Because many DOE field office staff are involved in decisions that require ecological information, it is important that the applicability of basic ecological concepts and ecological impact assessment methodologies to contaminated waste site remediation be clearly understood. The user of this guidance document will find references to ecological information and evaluations that may be required at various stages of the RI/FS process. Guidance is provided in the form of discrete modules that contain step-by-step procedures for specific tasks. The guidance provided herein is also applicable, in part, to the needs of DOE line managers charged with the responsibility for conducting natural resource damage assessments (NRDAs), although NRDAs are not the subject of this document.

This guidance document also provides an overview of the RI/FS process. Each element of the process is addressed relative to ecological assessment planning, evaluation, and risk determination. Detailed descriptions of specific field and laboratory ecological or toxicity testing methods are not included in this document. Where possible, guidance is included for determining the adequacy of methods needed to conduct an ecological assessment (e.g., quantitative versus qualitative methods, laboratory versus field analyses, or situations requiring both field sampling and laboratory testing). 


\section{DESCRIPTION OF THE ECOLOGICAL RISK ASSESSMENT PROCESS}

The distinction between an ecological assessment and an ecological risk assessment should be considered before the guidance set forth in this document is used. These terms are often used interchangeably among ecologists and in the scientific and regulatory literature, but in terms of the CERCLA process, there are differences between their meanings. Ecological

The EPA (1992a) defines ecological risk assessment as the process of evaluating the likelihood that adverse ecological effects may occur or are occurring as a result of exposure to one or more stressors.

assessments have evolved through time with passage of the National Environmental Policy Act (NEPA) in 1969. Historically, ecological assessments have been used to determine the impacts to ecological systems resulting from proposed human activities and have included predictions of impact, risk, and damage to these systems. Ecological assessments also have been used to support development of environmental standards based on laboratory and field measures of toxicological effects of pollutants. An ecological risk does not occur unless a stressor (1) has an inherent ability to cause one or more adverse effects and (2) co-occurs with or contacts an ecological component (i.e., organism, population, community, or ecosystem) long enough and at a sufficient intensity to elicit the identified adverse effect. A stressor, for purposes of this guidance docunent, is a radiological or chemical entity that can induce an adverse effect to individual organisms or populations or can cause loss of an ecosystem function. Ecological risk assessments at the CERCLA site will often involve more than one stressor and ecological component. This definition of ecological risk assessment will be implied throughout the guidance document.

An ecological risk assessment may be warranted at several stages in the RI/FS process. In an emergency situation, an assessment may be required in a relatively short time when removal actions must be performed quickly. In certain situations, ecological data should be collected during all stages of the remediation process. These data may support an ecological risk assessment to determine the baseline of potential and actual effects on biota and habitats in the absence of remedial action or to ensure an environmental standard is

Preparation of an RIIFS Work Plan will require that ecologists become familiar with information on (1) the hazardous substances being evaluated, (2) the scoping process, (3) baseline risk assessment procedures, and (4) details of site ecosystem dynamics. The modules used in this guidance establish a logical sequence of stages in the RI/FS process and emphasize the need to consider ecological information at each stage. 
being met during remediation. Data collected before and during remediation will be useful in designing programs to monitor long-term effectiveness in cases where the technology used for the remedial action is relatively new.

Considerable attention has been given recently to conducting ecological risk assessments. Suter (1993) provides information on assessment and measurement endpoints, toxicity assessments, and the importance of models in ecological risk assessment. Maughan (1993) evaluates issues related to ecological risk from a regulatory perspective and includes case studies of two Superfund sites in the northeastern United States. Bartell et al. (1992) present a risk prediction methodology for measuring toxic chemical effects on natural aquatic ecosystems.

The major emphasis of this document is on ecological issues pertinent to developing an ecological work plan as a component of the overall RI/FS work plan. However, guidance is also presented on how to determine when an ecological risk assessment is needed and what ecological input is needed to implement commitments made in the record of decision documenting the selected remedial action. The latter may require ecological monitoring to document remedial action effectiveness.

The most important categories of information to be considered by ecologists in preparing the ecological work plan are:

- Applicable statutes and regulations governing natural resources,

- Knowledge of the hazardous substances' radiological/chemical characteristics and distributions,

- Ecologicai resources that are or may be receptors and associated measurement and assessment endpoints, and

- Extent of contamination of both on-site and off-site ecosystems from site exposure.
Information obtained in examining the four information categories should be summarized and presented in background sections of the ecological work plan. These sections will support the rationale described in descriptive sections of the work plan for laboratory testing and field sampling/measurements. Unless detailed planning is carried out to identify: (1) appropriate species to be sampled, (2) measurement and assessment endpoints, and (3) hazardous substance characteristics, the work plan sampling activities that are inappropriate for providing data needed by analysts conducting the baseline risk assessment. This point cannot be overemphasized. Also, the establishment of Biological Technical Assessment Groups by the EPA to provide technical assistance in the RI/FS process can serve to focus the ecological data collection needs before and during preparation of the work plan. may describe laboratory and field 


\section{DOCUMENT FORMAT}

An overview of the RI/FS process is shown in Figure 1.1. The outline of this document follows this overview figure, showing the various stages where ecological input is needed for the decision maker. Specific stages in the RI/FS planning, scoping, and work plan development and implementation processes requiring ecological input and technical decisions are depicted in Figures 1.2 and 1.3.

Part I of this document provides an overview and description of ecological aspects necessary for proper planning and scoping of the RI/FS. Part II presents diagrams and associated text detailing modules related to the ecological work plan development and implementation. Each module contains graphics to orient the user to the current location in the overall guidance document and to guide the user to subsequent document sections. The modules are designed to guide the user on "what to do" and "when to do it" in ecological planning and decision making for the RI/FS process. The modules present guidance information in a concise manner, generally in step-wise fashion. However, activities depicted in some modules may be taking place within the same general time period. For example, initial preparation of a work plan approach could occur during project scoping (Module 5), concurrent with developing a site ecological conceptual model (Module 6) and conducting detailed characterization of site physical features (Module 7).

In Part II, each module is presented in "open book" format, with graphical information appearing on the left-hand page and relevant narrative discussion beginning on the right-hand page and continuing on successive pages if needed.

The narrative is used to elaborate details and includes information pertinent to statutory or regulatory citations, milestones, appropriate technical references, and other sources of information.

A master list of references cited in Parts I and II of this document is provided at the end of Part II (Chapter 7). In addition, the specific references cited in each subsection in Parts I and II are listed at the end of that subsection. The complete citations in these subsections are given as they appear in the master list in Chapter 7.

Appendix A of this document provides an example of a generic ecological work plan. Appendixes B and $\mathrm{C}$ are annotated outlines for an ecological field sampling plan and quality assurance project plan, respectively. Appendix D provides an EPA table of the sensitive environments rating values; while Appendix $\mathrm{E}$ is a listing of EPA Regional Biological Technical Assistance Group (BTAG) coordinators and contacts. 


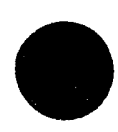

From:

Preliminary Assessment Site Inspection

NPL Listing

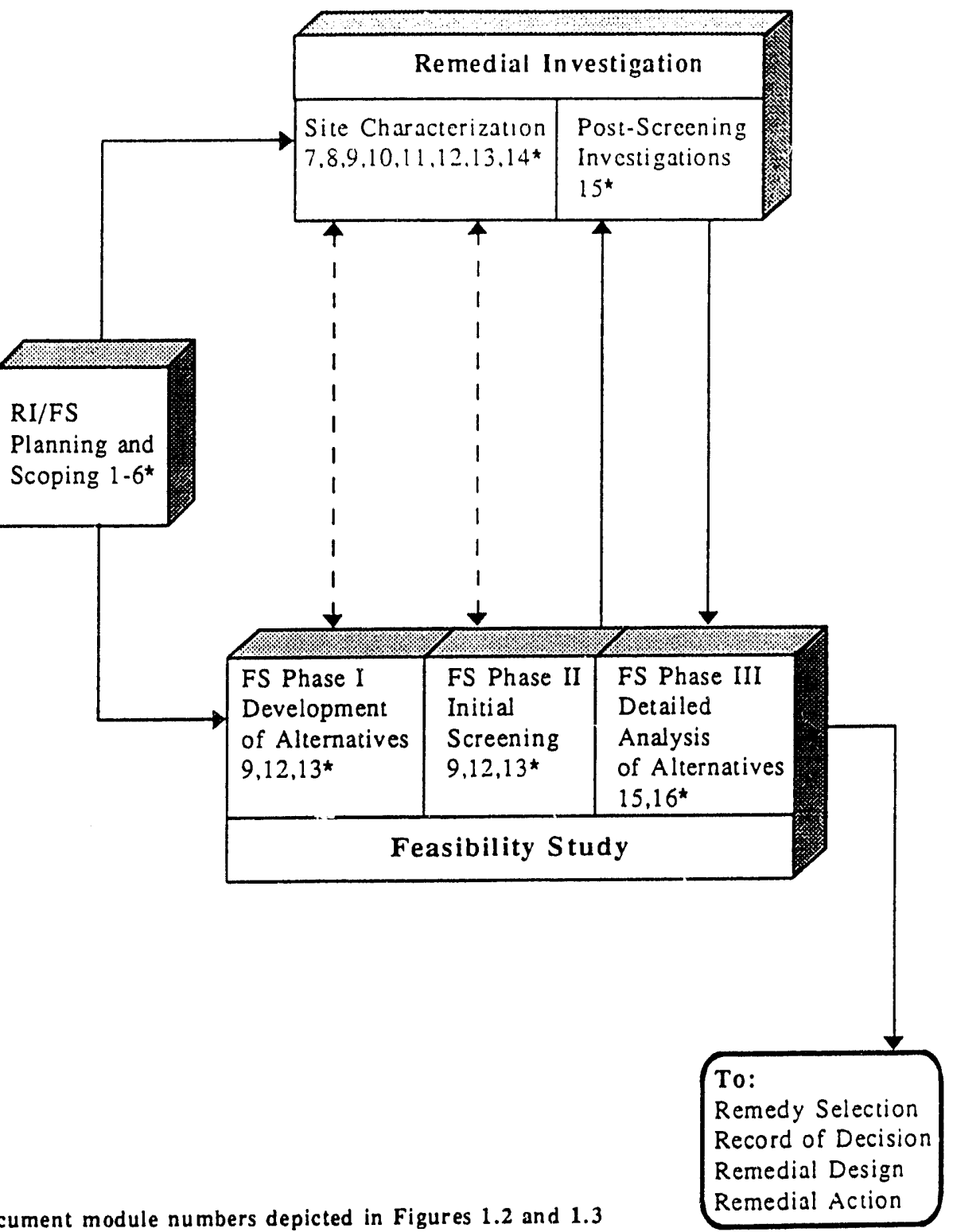

\section{FIGURE 1.1 Overview of the RI/FS Process (modified from EPA 1988a)}



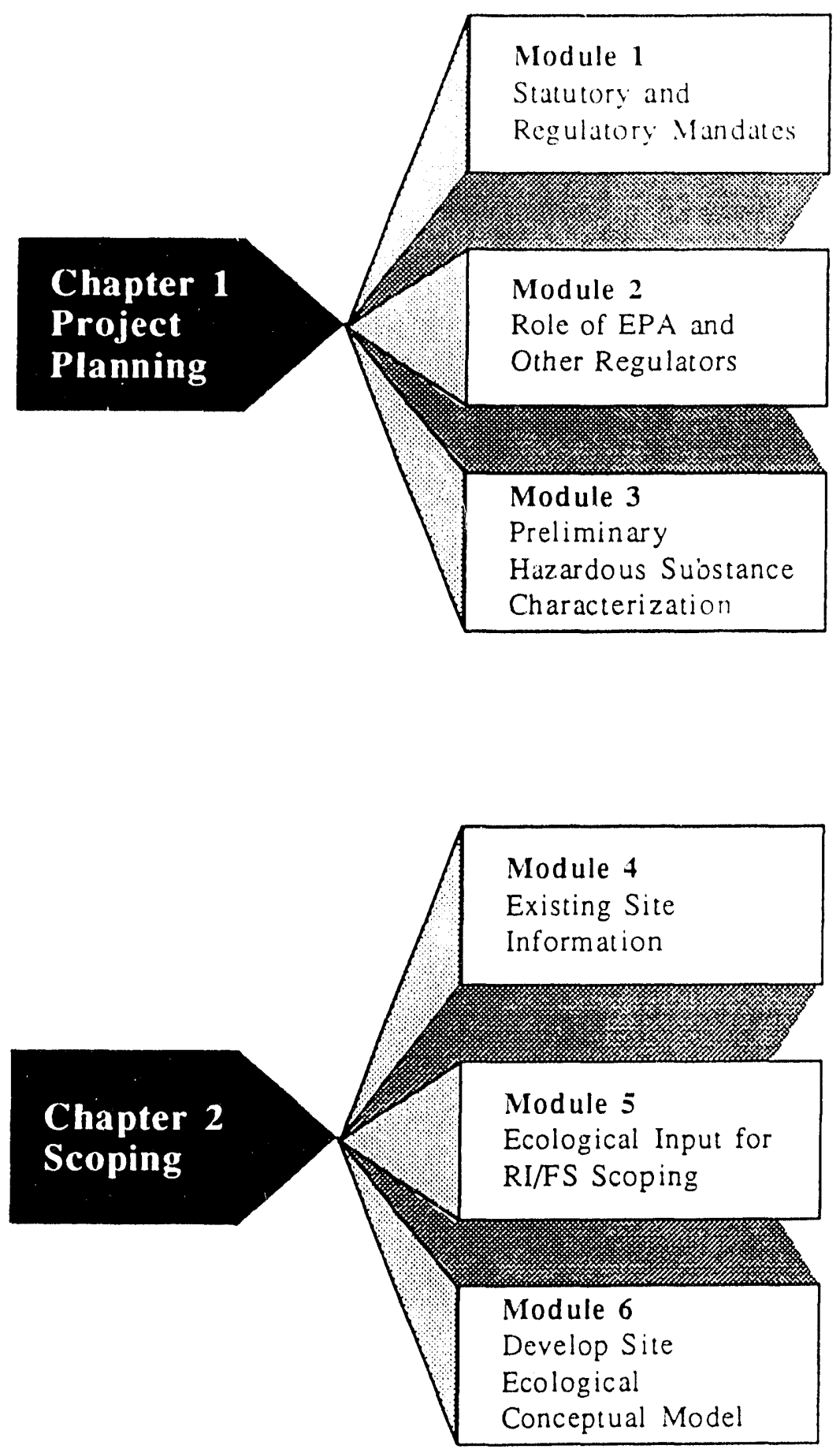

FIGURE 1.2 Planning and Scoping Stages in RI/FS Planning 

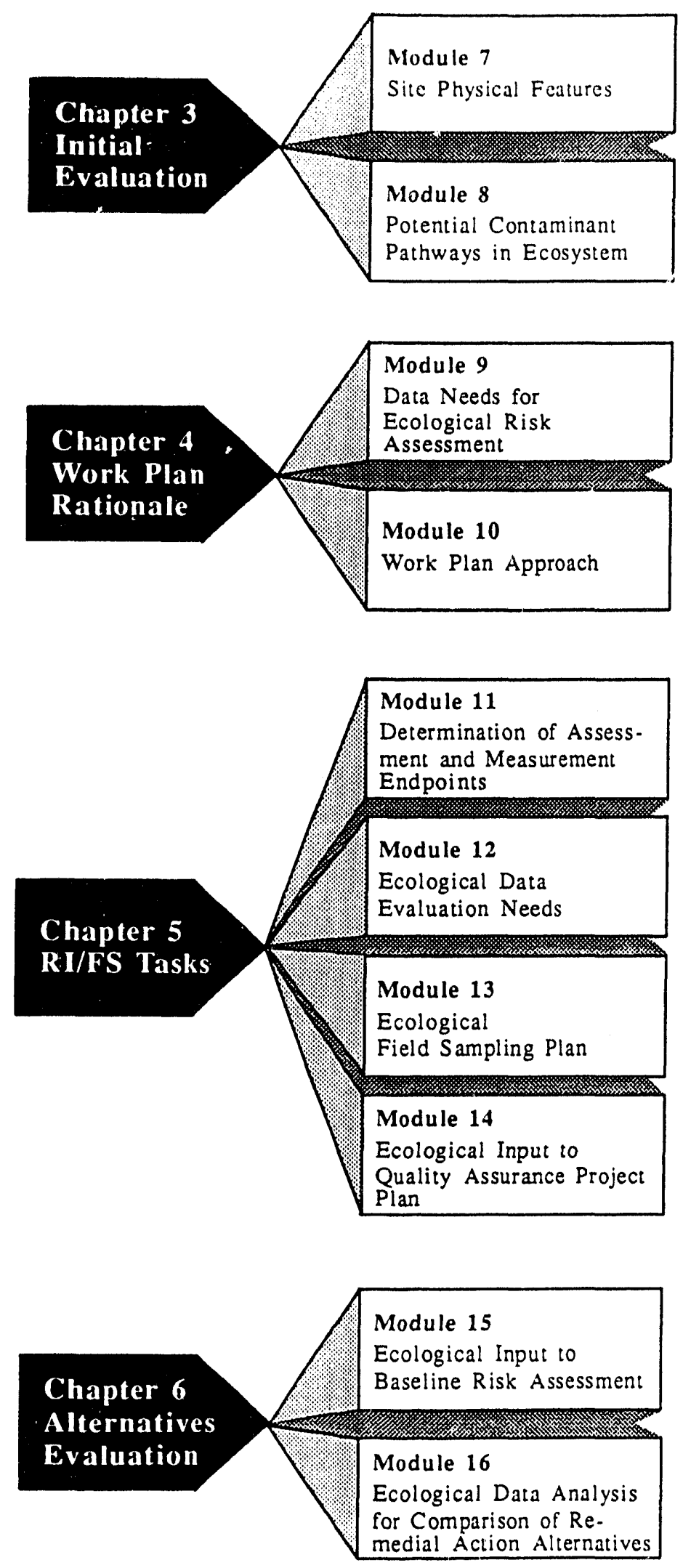

FIGURE 1.3 Work Plan Development and Implementation Stages in RI/FS Planning 


\section{KEY TO THE GRAPHIC APPROACH}

Purpose: Graphic (i.e., flowchart) guidance provides thorough and accurate information in a logical step-wise format. This guidance document uses diagrams, flowcharts, and supplemental text.

Structure: This guidance document subdivides CERCLA activities pertaining to ecological risk into modules. Each module consists of the following elements:

- Flowcharts presenting a decision process for applying regulations,

- Diagrams showing elements of plans or processes, and

- Text of supplemental explanatory information on the pages opposite the flowcharts.

Headings: Headings label sections of the flowchart and associated supplemental text.

Flowchart

symbols: The symbols used in the flowcharts in this document are explained in Figure 1.4.

\section{References}

EPA, 1988a. Guidance for Conducting Remedial Investigations and Feasibility Studies under CERCLA, Interim Final, report EPA/540/G-89/004, OSWER Directive 9335.3-01, U.S. Environmental Protection Agency, Washington, D.C.

EPA, 1989a. Ecological Risk Assessment Methods: A Review and Evaluation of Past Practices in the Superfund and RCRA Programs, report EPA/230/03-89/044, U.S. Environmental Protection Agency, Washington, D.C.

EPA 1992a. Framework for Ecological Risk Assessment, report EPA/630/R-92/001, U.S. Environmental Protection Agency, Washington, D.C. 
- Ovals represent the beginning of a new flowchart;

- Solid-Line Rectangles indicate actions that should be completed;

- Diamonds represent decision points. (Evaluate the question contained in the diamond and follow the appropriate path: Yes or No);

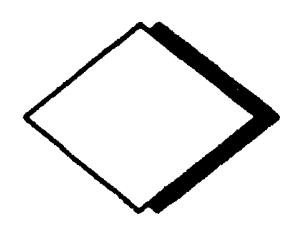

- Shaded, Dashed-Line Rectangles contain notes or "continued on," "continued from," or "proceed to" instructions that direct the reader to different parts of the flowchart or the guidance; and

- Circles indicate that the flowchart continues on the next page or continues from the previous page of the flowchart.

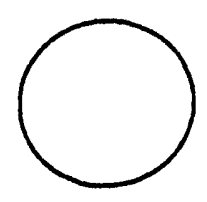

- Books signal reference callouts.
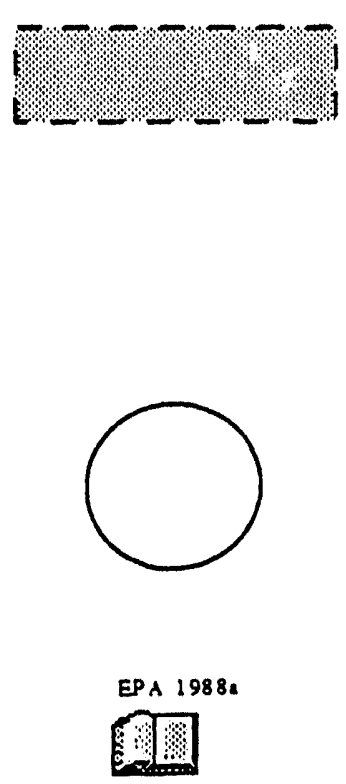

FIGURE 1.4 Explanation of Flowchart Symbols 


\section{PART II: MODULE DESCRIPTIONS}

\section{CONTENTS}

Chapter 1: Project Planning $\ldots \ldots \ldots \ldots \ldots \ldots \ldots \ldots \ldots \ldots \ldots \ldots \ldots \ldots$

Chapter 2: Scoping $\ldots \ldots \ldots \ldots \ldots \ldots \ldots \ldots \ldots \ldots \ldots \ldots \ldots \ldots \ldots$ II-23

Chapter 3: Initial Evaluation $\ldots \ldots \ldots \ldots \ldots \ldots \ldots \ldots \ldots \ldots \ldots \ldots \ldots$ II-41

Chapter 4: Work Plan Rationale $\ldots \ldots \ldots \ldots \ldots \ldots \ldots \ldots \ldots \ldots \ldots$

Chapter $5:$ RIFS Tasks $\ldots \ldots \ldots \ldots \ldots \ldots \ldots \ldots \ldots \ldots \ldots \ldots \ldots \ldots \ldots$

Chapter 6: Alternatives Evaluation $\ldots \ldots \ldots \ldots \ldots \ldots \ldots \ldots \ldots \ldots \ldots$

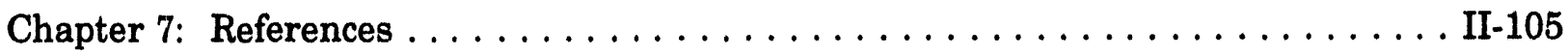




\section{CHAPTER 1}

\section{Project Planning}

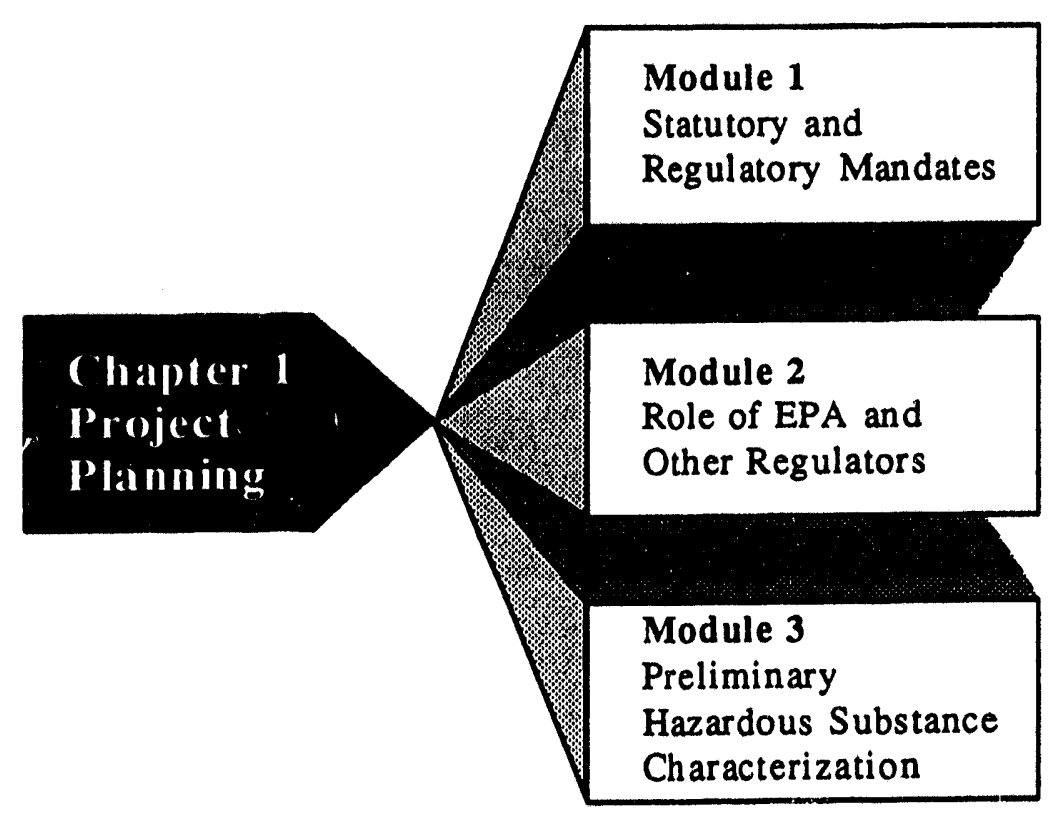

\section{CONTENTS}

Module 1: Statutory and Regulatory Guidance Mandates $\ldots \ldots \ldots \ldots \ldots$ II-7

Module 2: Role of EPA and Other Regulators $\ldots \ldots \ldots \ldots \ldots \ldots \ldots$ II-13

Module 3: Preliminary Hazardous Substance Characterization . . . . . . . . . II-17 


\section{CHAPTER 1: PROJECT PLANNING}

Familiarity with the National Oil and Hazardous Substances Pollution Contingency Plan (NCP) (40 CFR Part 300) is essential in order to understand the responsibilities of federal agencies engaged in remediation planning for hazardous waste sites. Planning the project requires considerable understanding of the types and nature of chemical contaminants present at the site, their locations, and the applicable statutes, regulations, and specific federal agency guidance for the environmental resources adversely affected by the contaminants being evaluated. Planning should consider ecological issues to be addressed in the ecological work plan, both in evaluating the current site condition and in comparing various remediation alternatives.

The three modules presented in this chapter address steps to be taken in advance of ecological work plan preparation. The material presented assumes that a detailed ecological assessment is necessary to support the overall project baseline risk assessment and feasibility study. The participation

Planning should consider ecological issues to be addressed in the ecological work plan both in evaluating the current site condition and for comparing various remediation alternatives.

of the EPA Biological Technical Assistance Group (BTAG) and ecologists from other federal or state agencies in the review and oversight of the DOE project should be recognized by the DOE environmental restoration program manager (ERPM) and on-site coordinator in planning the project. A thorough knowledge of ecosystems in the project area and knowledge of past releases and contaminants are important elements in defining the objectives and scope of the ecological assessment.

The EPA (1992b) has issued guidance to federal agencies on work scope development for ecological assessments. This publication is one issue in a series of supplemental guidance reports under the series name of "ECO Update" intended to supplement the Risk Assessment Guidance for Superfund, Volume II, Environmental Evaluation Manual (EPA 1989c). The role of the BTAGs, elements of ecological assessment work scope, and ways of evaluating contractor qualifications are discussed in the ECO Update guidance. Project ecologists should refer to this guidance as well as other recent publications that address ecological risk assessment (e.g., Bartell et al. 1992; Maughan 1993; Suter 1993). These publications provide an overview of the process, suggested methods, and case studies.

The DOE also has recently issued more specific guidance on RI/FS techniques (DOE 1993a). A draft report has also been issued by DOE on policy and implementation planning for conducting ecological risk assessments at DOE facilities (DOE 1993b). 


\section{References}

Bartell, S.M., et al., (eds.), 1992. Ecological Risk Estimation. Lewis Publishers, Chelsea, Mich.

DOE, 1993a, Remedial Investigation/Feasibility Study (RI/FS) Process and Techniques Guidance, Interim Draft Final, U.S. Department of Energy, Office of Environmental Guidance, Washington, D.C., May.

DOE, 1993b, Policy Framework and Implementation Plan for Using Ecological Risk Assessment at DOE Facilities, DOE/RL/01830-H16, U.S. Department of Energy, Washington, D.C.

EPA, 1989c. Risk Assessment Guidance for Superfund - Vol. II, Environmental Evaluation Manual, report EPA/540/89/001, U.S. Environmental Protection Agency, Washington, D.C..

EPA, 1992b. ECO Update, Developing a Work Scope for Ecological Assessments, U.S. Environmental Protection Agency, Office of Solid Waste and Emergency Response, Intermittent Bulletin 1(4):1-15, Washington, D.C.

Maughan, J.T., 1993. Ecological Assessment of Hazardous Waste Sites. Van Nostrand Reinhold, New York.

Suter, G.W., II, 1993. Ecological Risk Assessment. Lewis Publishers, Chelsea, Mich. 


\section{MODULE 1:}

\section{STATUTORY AND REGULATORY GUIDANCE MANDATES}

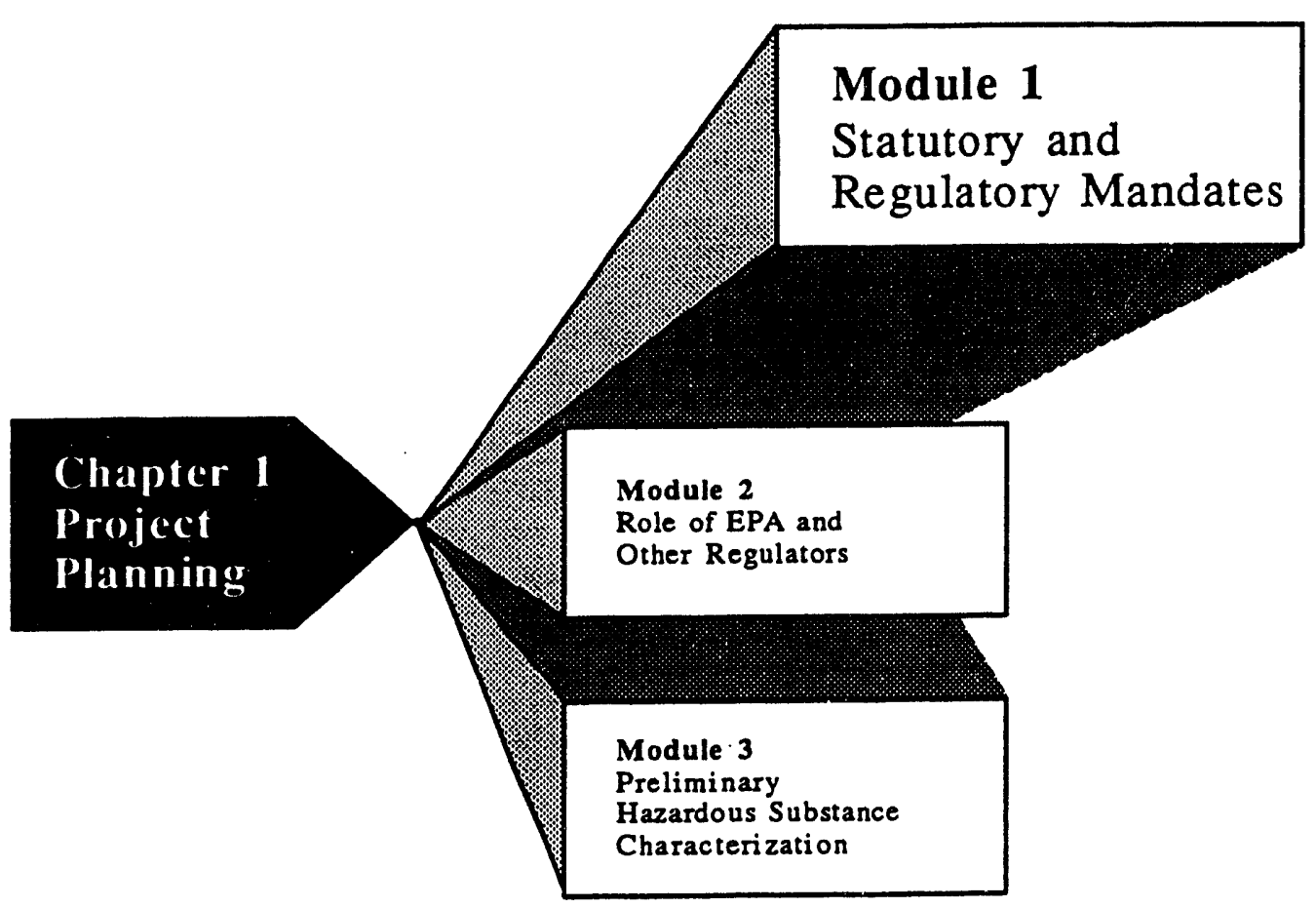




\section{Module 1: Statutory and Regulatory Guidance Mandates}

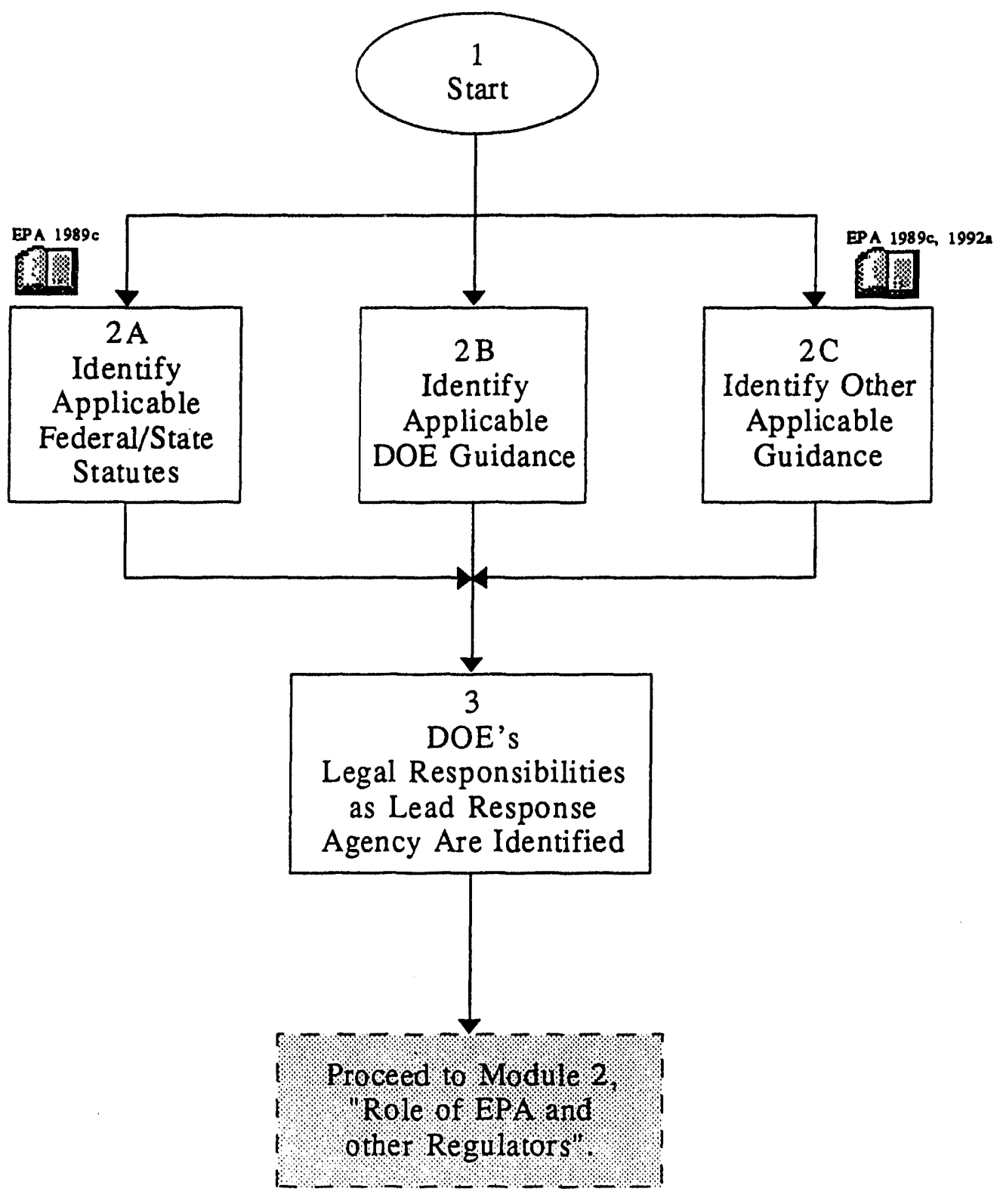


Draft: August 1993

II -9

\section{MODULE 1: STATUTORY AND REGULATORY MANDATES}

\section{Step 1 Start.}

Step 2a Early in the review process, DOE should identify all federal and state statutes, and their implementing regulations, that are applicable to the project (EPA 1989c). The NCP defines these requirements as applicable or relevant and appropriate requirements (ARARs). ARARs can be specific with respect to a chemical, its location, or action. Table 1.1 (next page) provides a listing of ARAR examples. The DOE ERPM is responsible for determining which of the ARARs would be applicable to the CERCLA project. At DOE CERCLA sites, executive orders (Nos. 11990, 11988) pertaining to wetlands and floodplains may also be considered locationspecific ARARs.

Various federal statutes pertain to ecological resources at the CERCLA site. The Endangered Species Act, Bald and Golden Eagle Protection Act and Migratory Bird Treaty Act require federal agencies to examine proposed actions relative to species impacts pertaining to habitat losses or direct losses of individual organisms. The Fish and Wildlife Service (FWS 1979) provides a selected list of federal laws and treaties that pertain to ecological resources. The DOE ERPM also may need to examine potential impacts of site remediation to air quality and water quality requirements established under the Clean Water Act and Clean Air Act. Any dredging or fill actions in navigable waters of the United States require an evaluation by the U.S. Army

The EPA (1991a) has identified the following general types of ARARs: (1) chemical-specific: health or risk management-based methodologies that, when applied to sitespecific conditions, result in the establishment of numerical values (e.g. chemical-specific concentrations in a given medium); (2) locationspecific: restrictions placed upon the concentration of hazardous substances or the conduct of activities solely because they are in special locations such as wetlands; and (3) action-linked: technology or activity-based requirements or limitations on actions taken with respect to hazardous wastes. Corps of Engineers to review the action and, if necessary, grant a permit under Section 404 of the Clean Water Act. The permit requirement is waived for dredge and fill actions that take place on the DOE CERCLA site proper.

Step 2b DOE guidance exists for ecological evaluations at CERCLA sites where DOE has responsibility as the natural resource trustee (DOE 1991). This document provides guidance DOE should follow in assessing injury to natural resources from exposure to "hazardous substances" and in determining monetary compensation from injury 
TABLE 1.1 Examples of Applicable or Relevant and Appropriate Requirements (ARARs)

\section{Chemical-Specific ARARs}

- Safe Drinking Water Act and regulations (federal and/or state)

- Resource Conservation and Recovery Act (RCRA) Groundwater Protection Standards (federal and state-equivalent)

- Nuclear Regulatory Commission Standards for Protection Against Radiation

- State radiation protection standards

- State radiation emission standards

- Clean Water Act and regulations (federal)

- State Water Quality Standards

- Toxic Substances Control Act and regulations

- National Emission Standards for Radionuclide Emissions from DOE facilities

- EPA Radiation Protection Standards for managing and disposing of spent nuclear fuel, high-level, and transuranic radioactive wastes

- Clean Air Act

- National Primary and Secondary Ambient Air Quality Standards

\section{Location-Specific ARARs}

- Endangered Species Act

- Bald and Golden Eagle Protection Act

- Migratory Bird Treaty Act

- RCRA treatment, storage, and disposal (TSD) siting requirements

- Executive Order 11990 "Protection of Wetlands"日

- Executive Order 11988 "Floodplain Management"a

- Clean Water Act, Section 404, wetlands protection

- Protection of areas that are part of the National Wildlife Refuge System

- Fish and Wildlife Coordination Act

- Wild and Scenic Rivers Act

- National Historic Preservation Act

\section{Action-Specific ARARs}

- RCRA TSD facility requirements

- RCRA land disposal restrictions

- U.S. Army Corps of Engineers dredging and filling permits

- National Pollutant Discharge Elimination System

- Clean Air Act: National Emission Standards for Hazardous Air Pollutants

a Executive Orders 11990 and 11988 are codified for DOE at 10 CFR 1022 (Appendix C). 10 CFR 1022 is a location-specific ARAR for DOE. 
done to natural resources. Ecologists should refer to the DOE CERCLA Reference Book (Oak Ridge National Laboratory [ORNL] 1993) for further information on regulatory requirements of the RI/FS process. This reference book, updated regularly by the DOE Office of Environmental Guidance, contains a current copy of CERCLA and implementing regulations for CERCLA evaluations, including information on preliminary site evaluations, such as ecological toxicity tests and bioaccumulation determinations.

Step 2c EPA guidance has been published on ecological assessments and procedures pertinent to CERCLA sites (EPA 1989b, 1989c, 1992a).

Step 3 DOE has identified and documented a preliminary list of ARARs for the project. DOE, as a lead agency, and oversight agencies shall notify each other of ARARs in writing no later than the early stages of the comparative analysis of remedial action alternatives [NCP Part 300.430(e)9]. As lead response agency, DOE also must notify oversight agencies of other legal responsibilities. Ecologists should use the statutes identified in Step $2 a$ above as background information in scoping the initial draft of an ecological work plan.

\section{References}

DOE, 1991. Natural Resource Trusteeship and Ecological Evaluation for Environmental Restoration at Department of Energy Facilities, report DOE/EH-0192, U.S. Department of Energy, Washington, D.C.

EPA, 1989b. Ecological Assessment of Hazardous Waste Sites: A Field and Laboratory Reference, report PB89-205967, U.S. Environmental Protection Agency, Washington, D.C.

EPA, 1989c. Risk Assessment Guidance for Superfund - Vol. II, Environmental Evaluation Manual, report EPA/540/89/001, U.S. Environmental Protection Agency, Washington, D.C.

EPA, 1991a. Risk Assessment Guidance for Superfund: Volume 1-Human Health Evaluation Manual (Part B, Development of Risk-based Preliminary Remediation Goals), Office of Emergency and Remedial Response, Publication 9285.7.01B, U.S. Environmental Protection Agency, Washington, D.C.

EPA, 1992a. Framework for Ecological Risk Assessment, report EPA/630/R-92/001, U.S. Environmental Protection Agency, Washington, D.C.

FWS, 1979. Selected List of Federal Laws and Treaties Relating to Sport Fish and Wildlife, U. S. Department of Interior, Fish and Wildlife Service, Washington, D.C.

ORNL, 1993. Environmental Guidance Program Reference Book, Comprehensive Environmental Response, Compensation, and Liability Act, report ORNL/M-2261, Oak Ridge National Laboratory, Oak Ridge, Tenn. 


\section{MODULE 2:}

\section{ROLE OF EPA AND OTHER REGULATORS}

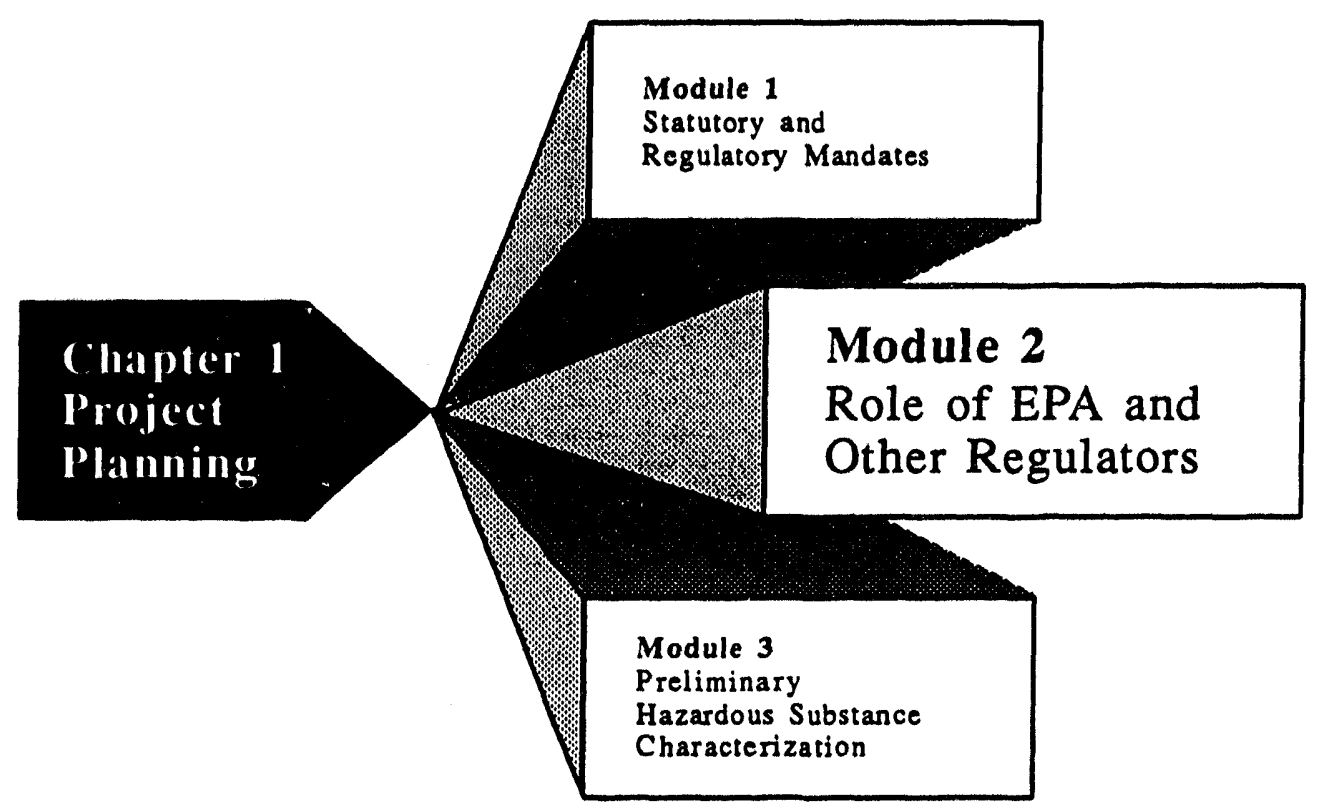




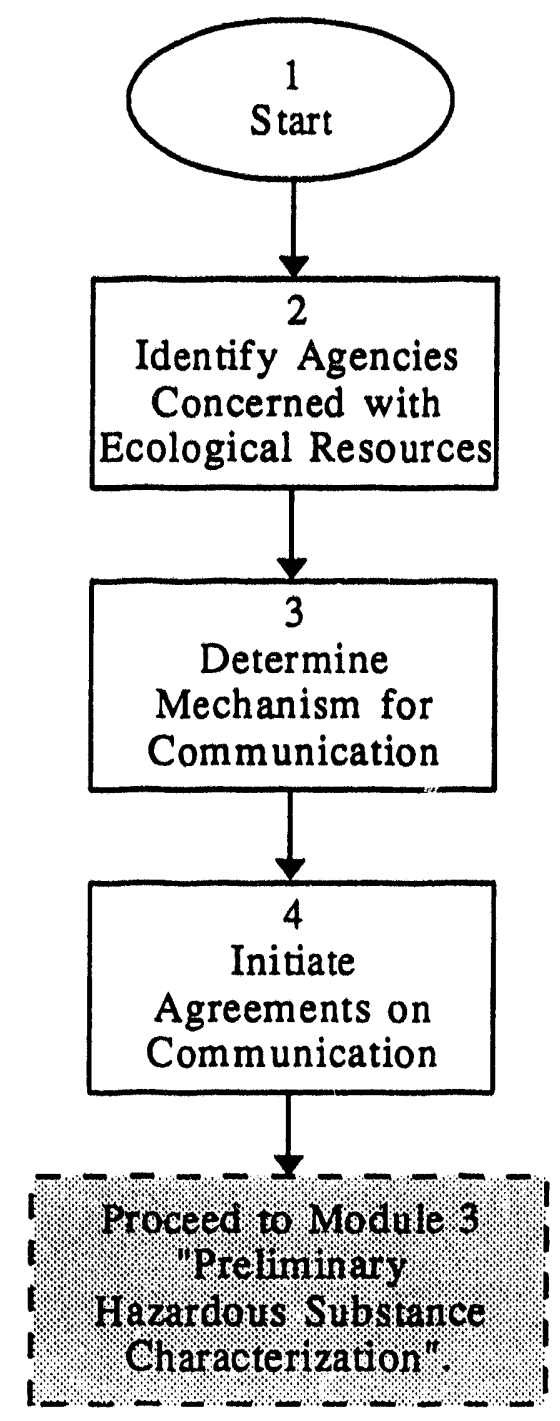




\section{MODULE 2: ROLE OF EPA AND OTHER REGULATORS}

Step 1 Start.

Step 2 Roles and responsibilities of various federal, state, and local agencies should be identified at the project outset. The EPA and state agencies charged with the responsibility as the point of contact for federal agencies initiating a remediation project can provide valuable assistance. Project ecologists should identify points of contact for each federal and state agency and Indian Tribe having regulatory responsibility for biological resources. The EPA regional office for the CERCLA site being evaluated can provide information on federal and state agencies having regulatory or statutory responsibility for biological resources. Appendix $\mathbf{E}$ lists the EPA BTAG coordinators who serve as contacts for obtaining this information.

Step 3 The U.S. Fish and Wildlife Service (FWS), Army Corps of Engineers (COE), and appropriate state agencies (e.g., state wildlife agencies and departments of natural resources) and Indian Tribes should be contacted regarding their legal responsibilities and desired role in the CERCLA remediation process. Initial contacts often will provide an overview of a state agency's roles in past CERCLA actions and their likely involvement in the current project.

Step 4 In cases where an NRDA is warranted, administrative responsibilities of DOE and other agencies are defined in 43 CFR 11.32. These procedures define how a damage assessment plan should be developed. For responsibilities of other agencies on hazardous substance remediation projects, the user should refer to the NCP procedures, particularly 40 CFR Part 300.430, Remedial Investigation/Feasibility Study and Selection of Remedy (ORNL 1993). The DOE (1991) issued guidance on its responsibilities as a natural resource trustee.

State involvement in the RI/FS process and guidance on agreements between the EPA and states is provided in Part 300.515(d). When DOE is the lead agency, input to the EPA will be needed on any agreements reached with potentially responsible parties

A Federal Facility Agreement typically includes (1) a procedural framework and schedule for develop. ing, implementing, and monitoring appropriate response actions; (2) procedures for resolving disputes, assigning penalties for nonconformance, and ensuring public participation in the RI/FS process; (3) identification of what primary documents (i.e., RI/FS work plan, sampling and analysis plan, baseline risk assessment, remedial investigation, feasibility study, proposed remediation plan, and record of decision) DOE must prepare and submit to the EPA and state agencies; (4) secondary documents such as treatability study reports and reporis on preliminary analysis of alternatives; and (5) progress reports submitted at a specified frequency. 
resources, fish and game department, or Indian Tribes) involved with remediation planning and response.

A federal facility agreement (FFA) is drawn up to define involvement of the EPA, DOE, and appropriate state agencies in the RI/FS process.

\section{References}

DOE, 1991. Natural Resource Trusteeship and Ecological Evaluation for Environmental Restoration at Department of Energy Facilities, report DOE/EH-0192, U.S. Department of Energy, Washington, D.C.

ORNL, 1993. Environmental Guidance Program Reference Book, Comprehensive Environmental Response, Compensation, and Liability Act, report ORNL/M-2261, Oak Ridge National Laboratory, Oak Ridge, Tenn. 


\section{MODULE 3:}

\section{PRELIMINARY HAZARDOUS SUBSTANCE CHARACTERIZATION}

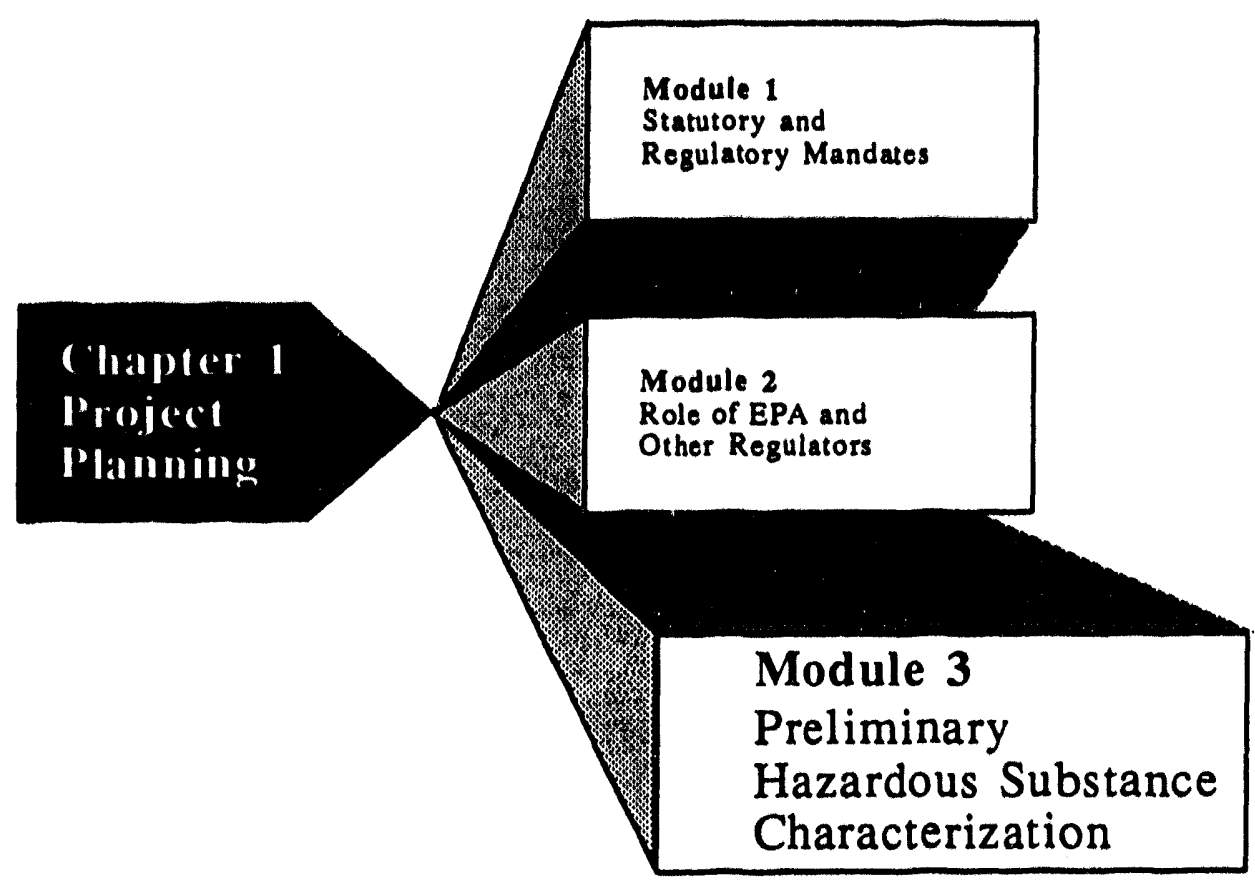




\section{Molule i: Preliminary Lazardous Substance Characterization}

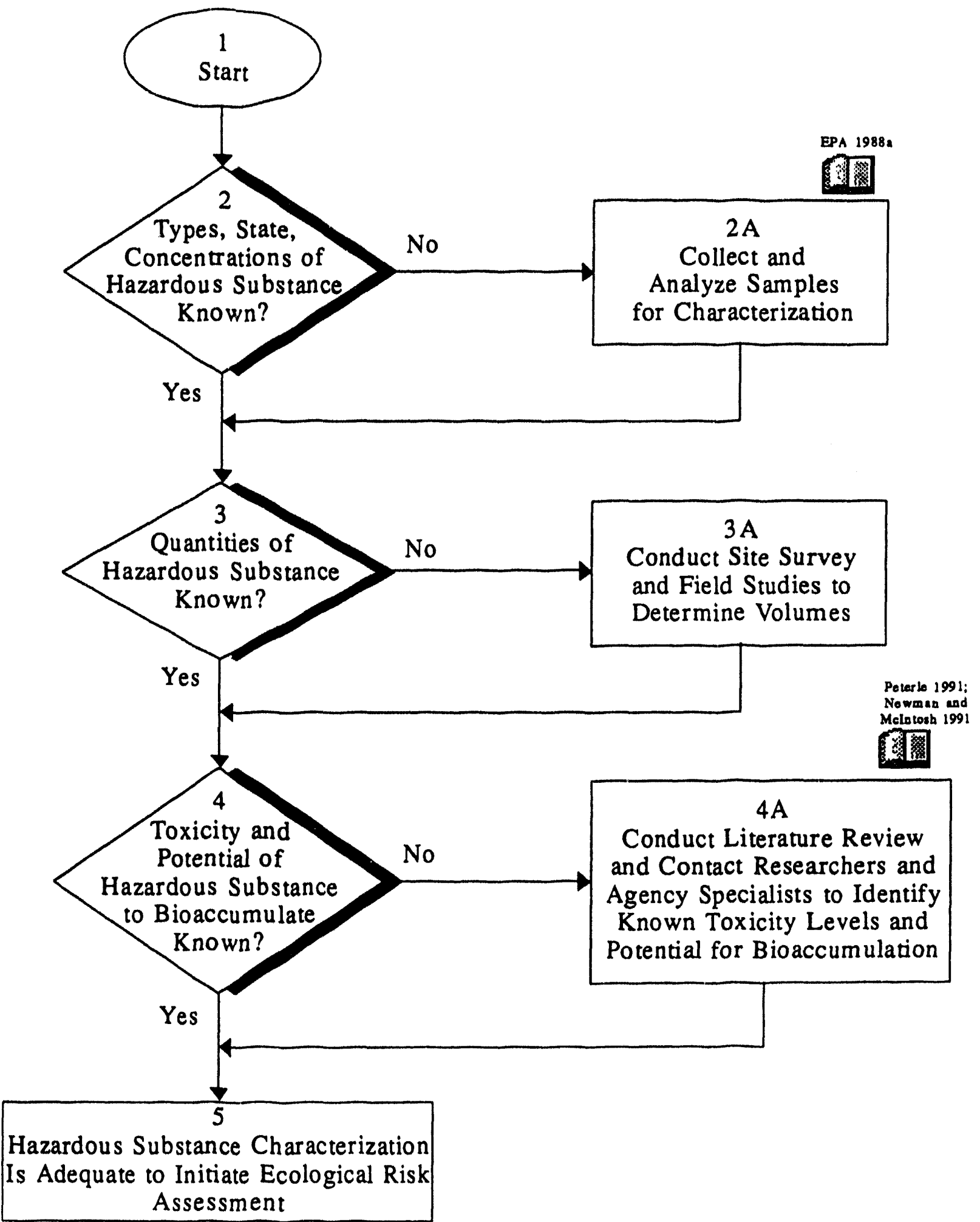




\section{MODULE 3: PRELIMINARY HAZARDOUS SUBSTANCE CHARACTERIZATION}

Step $1 \quad$ Start.

Step 2, 2a The DOE, as the lead agency, must characterize the nature of and threat posed by the hazardous substances. The DOE ERPM must develop an overall RI/FS work plan after a preliminary screening of the site is completed. As part of the overall RIFS process, existing information on hazardous substance type, state, and concentration must be obtained as a starting point in determining the potential threat to human health and the environment. For example, contaminants occurring at concentrations above regional background levels may be contaminants of concern; whereas those at or below regional concentrations would in all likelihood not receive further consideration as contaminants of concern (see

Identifying Contaminants of Ecological Concern

The following factors should be considered when identifying contaminants of concern: (1) environmental media concentration representing ecological exposure pathways, (2) frequency of occurrence (defining prevalence in site media); (3) backgrourd levels (indicating concentrations not attributable to the site); (4) bioavailability (presence of contaminant in a form that can affect biota); (5) physicochemical properties (e.g. volatility and solubility); (6) potential for bioconcentration and bioaccumulation (tendency to occur in biota at higher concentrations than surrounding environment); (7) potency (amount of toxicant capable of producing adverse effects); and (8) effects (e.g., acute and chronic responses) (EPA 199ii).

Step 3, 3a Site reconnaissance-level surveys may reveal information on the volume of hazardous substances in question. DOE and operating contractor files may contain records on the volumes of hazardous substances disposed of on-site.

Step 4, 4a Literature reviews (e.g., Peterle 1991; Newman and McIntosh 1991) may reveal information on toxicity, persistence in the environment, and propensity to bioaccumulate. Contacts with researchers and agency specialists are 
obvious means of obtaining current information on the hazardous substances being evaluated (see Appendix A, Section A.3.4)

Step 5 If information exists on all aspects of the hazardous substance, the RI/FS process may proceed to initiation of an ecological risk assessment and to the development of remedial action alternatives [NCP, Part 300.430, 2(d)]. For most sites, the hazardous substance cannot be completely characterized on the basis of preliminary information, thus necessitating the implementation of scoping and site characterization (Chapter 2).

\section{References}

EPA, 1988a. Guidance for Conducting Remedial Investigations and Feasibility Studies under CERCLA, Interim Final, report EPA/540/G-89/004, OSWER Directive 9335.3-01, U.S. Environmental Protection Agency, Washington, D.C.

EPA, 1991b. ECO Update, Ecological Assessment of Superfund Sites: An Overview, U.S. Environmental Protection Agency, Office of Solid Waste and Emergency Response, Intermittent Bulletin 1(2):1-8, Washington, D.C.

Newman, M.C., and A.W. McIntosh (eds.), 1991. Metal Ecotoxicology, Concepts and Applications. Lewis Publishers, Inc., Chelsea, Mich.

Peterle, T.J., 1991. Wildlife Toxicology. Van Nostrand Reinhold, New York. 


\section{CHAPTER 2}

\section{Scoping}

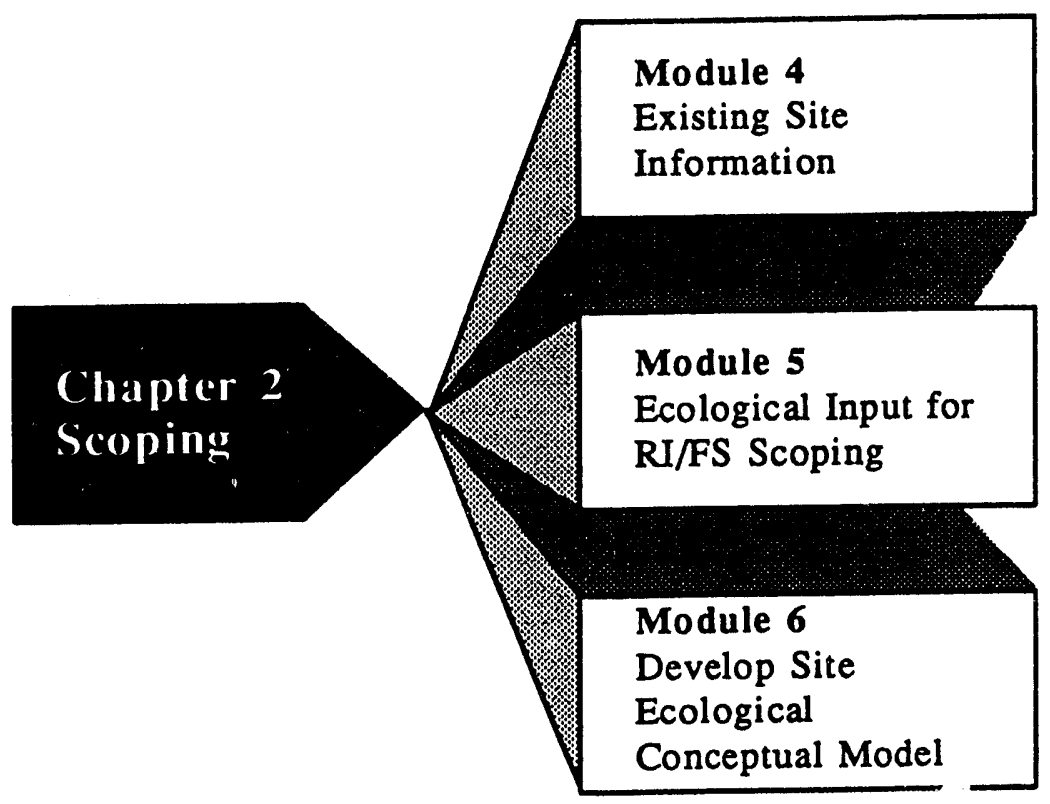

CONTENTS

Module 4: Existing Site Information $\ldots \ldots \ldots \ldots \ldots \ldots \ldots \ldots \ldots \ldots \ldots \ldots$ II-25

Module 5: Ecological Input for RIFS Scoping . . . . . . . . . . . . . . II-29

Module 6: Develop Site Ecological Conceptual Model . . . . . . . . . . . . II-33 


\section{CHAPTER 2: SCOPING}

Scoping activities involve collection and analysis of existing site information and development of a site ecological model that is consistent with and refines the conceptual site model. Existing ecological information may be insufficient to allow establishment of project goals or to identify important species or groups likely to be affected by hazardous substances. Limited field investigations should be undertaken in this case. EPA (1988a) guidance on scoping indicates that existing ecological information should be examined for the following topics:

- Location of any threatened, endangered, or rare species, sensitive environmental areas, or critical habitats on or near the site;

- Common flora and fauna of the site and surrounding areas; this information will provide an understanding of the most common species likely to be exposed to hazardous substances and the potential effects of other species through biomagnification; and

- Available results from any previous biological testing, such as data on acute or chronic toxicity or bioaccumulation. Literature searches to identify pertinent studies on the hazardous substances known to occur at the site will be useful for determining whether future field or laboratory tests might be required.

In addition, the project ecologist and ERPM can use any available past ecosystem modelling results or a geographic information system to display existing data and scope the extent of future studies to be described in the ecological work plan. The EPA framework steps (EPA 1992a) for ecological risk assessment will help to focus on the type of ecological data needed for determining risk of implementing various remedial action alternatives.

Ecological input may also be obtained during the community relations/public participation activities carried out as part of scoping. Activities the DOE must undertake in carrying out its community relations requirements at the CERCLA site are defined in the NCP [40 CFR Part 300.430(c)]. 


\section{References}

EPA, 1988a. Guidance for Conducting Remedial Investigations and Feasibility Studies under CERCLA, Interim Final, report EPA/540/G-89/004, OSWER Directive 9335.3-01, U.S. Environmental Protection Agency, Washington, D.C.

EPA, 1991b. ECO Update, Ecological Assessment of Superfund Sites: An Overview, U.S. Environmental Protection Agency, Office of Solid Waste and Emergency Response, Intermittent Bulletin 1(2):1-8, Washington, D.C.

EPA, 1992a. Framework for Ecological Risk Assessment, report EPA/630/R-92/001, U.S. Environmental Protection Agency, Washington, D.C. 


\section{MODULE 4:}

\section{EXISTING SITE INFORMATION}

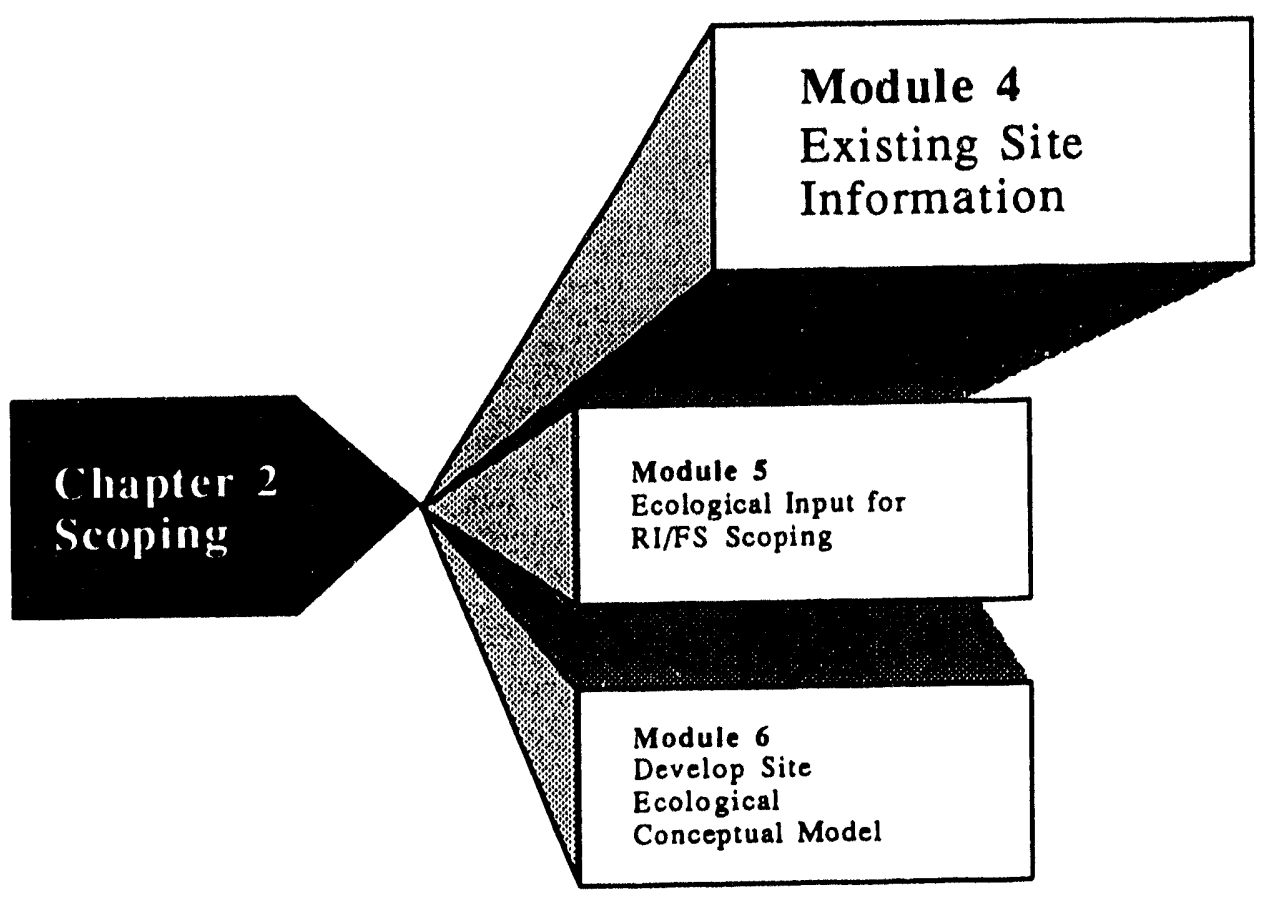




\section{Module 4: Ixisting Site Information}

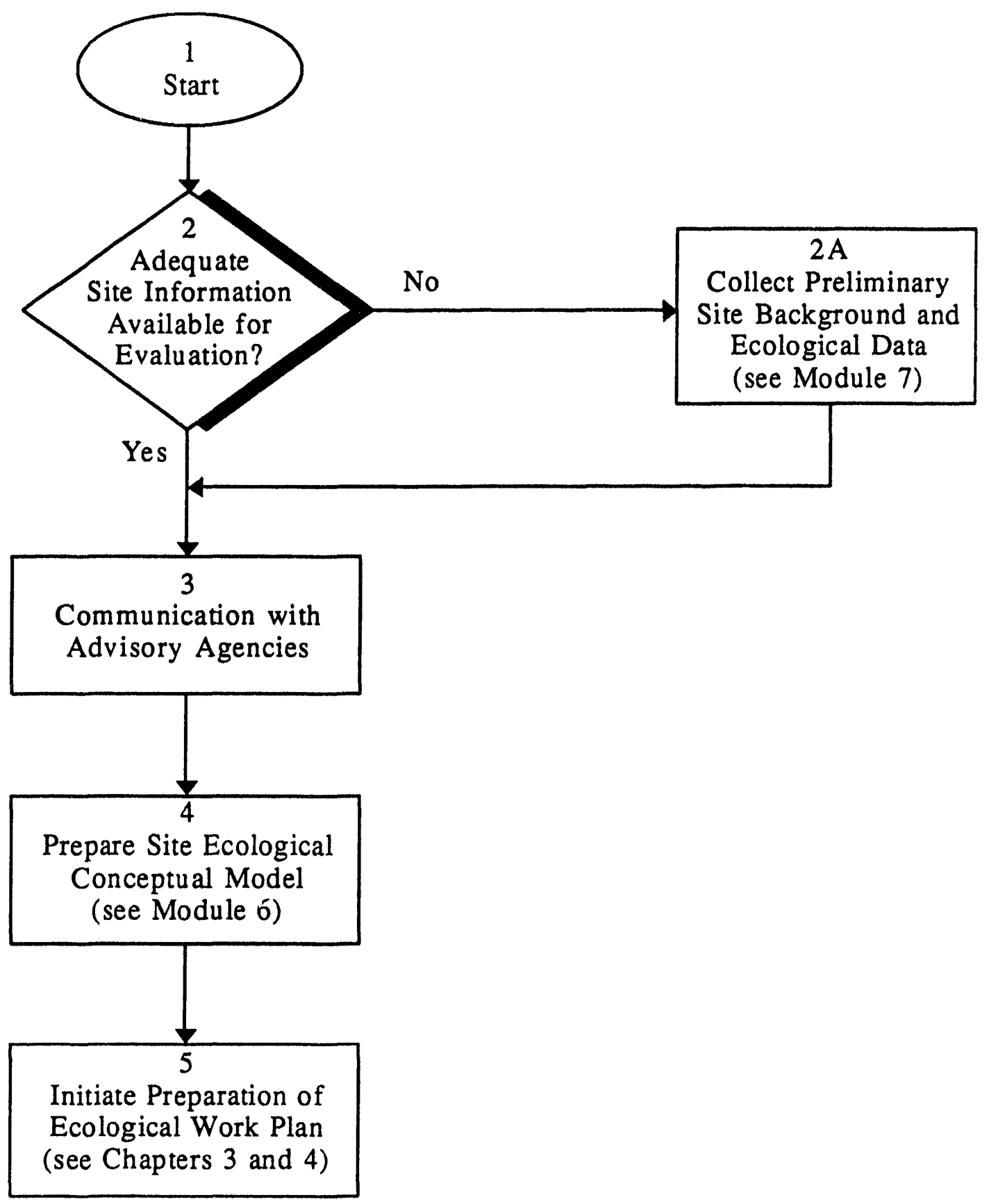




\section{MODULE 4: EXISTING SITE INFORMATION}

\section{Step 1 Start.}

Step 2 Program goals and objectives should be considered at the outset of scoping. Information on the site 'should be assembled for review by technical managers and the ERPM. Information should include results from any past removal actions or remedial activities, site preliminary assessment, site inspections, the National Priorities List (NPL) listing process, and results of previous characterization or scientific research conducted on the site (ORNL 1993) (see Appendix A, Section A.1.1)

Step 2a The DOE ERPM will collect preliminary ecological data at the site that is adequate to provide background information for

Existing Information

Available site information can be used to develop an initial awareness of site conditions and problems and to determine additional information that may be required to make technically defensible decisions about remedial action alternatives. Maximizing the use of available site information will help to avoid duplication of previous data collection efforts and help to focus data collection efforts required for the ecological assessment. interacting with advisory groups or state and federal agencies. Site data can also be obtained from a variety of reports (e.g., state publications or federal government reports of studies on ecological resources at the site or similar ecosystems in the site vicinity), other operable units, databases, and similar sources (see Appendix A, Section A.1.3). Limited field sampling may also be necessary.

Step 3 Meetings with advisory agencies or groups (e.g., BTAG) will facilitate identification of procedures and appropriate sequence of actions DOE should follow to address site problems, particularly for filling data gaps. Such procedures are needed to assure that DOE meets overall data quality objectives in the RI/FS process (see Appendix A, Section A.3).

RI/FS alternatives development cannot be initiated by DOE until site information has been reviewed and input from advisory groups and agencies has been evaluated.

Step 4 Site conceptual models can be developed once DOE and advisory groups and agencies evaluate existing information (see Module 6 for detailed guidance on the preparation of site ecological conceptual models). 
Step 5 The DOE ERPM should assemble scientific and engineering data in one location (e.g., project library) to assist managers faced with basic questions on remedial action alternatives design. These data will help to define additional laboratory and field data collection to be described in the ecological work plan.

\section{References}

ORNL, 1993. Environmental Guidance Program Reference Book, Comprehensive Environmental Response, Compensation, and Liability Act, report ORNL/M-2261, Oak Ridge National Laboratory, Oak Ridge, Tenn. 
MODULE 5:

\section{ECOLOGICAL INPUT FOR RIFS SCOPING}

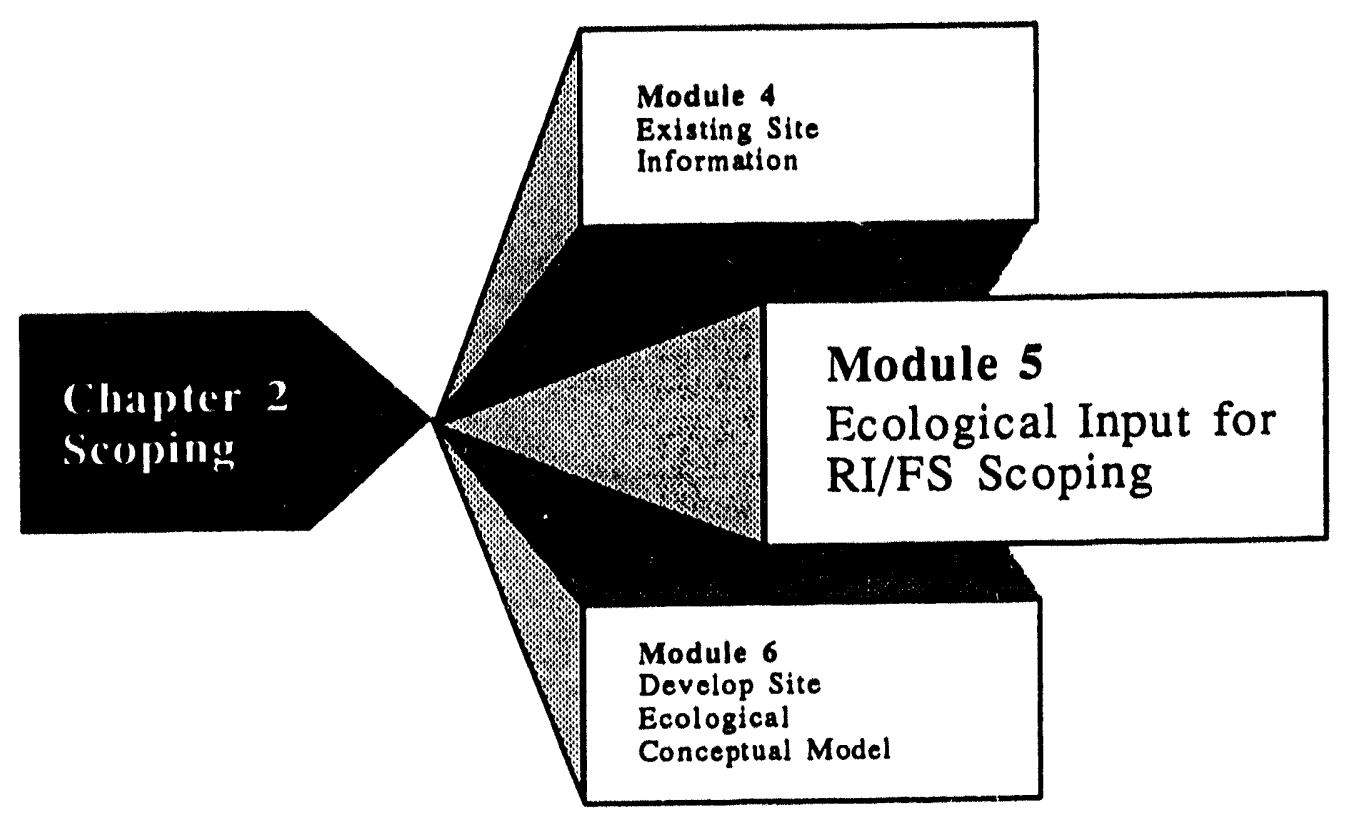




\section{Module 5: I:cological Input for RI/ISS Scoping}

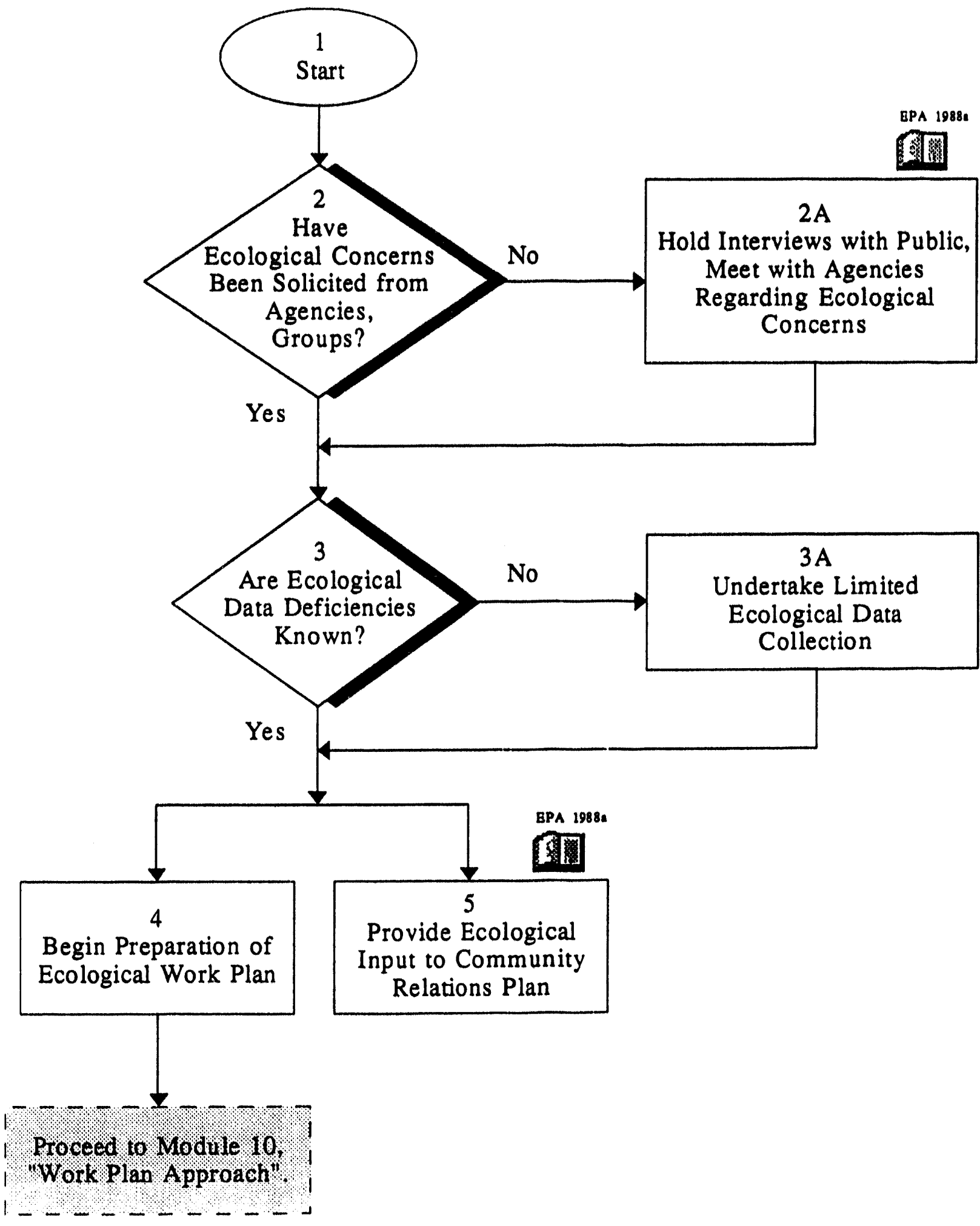




\section{MODULE 5: ECOLOGICAL INPUT FOR RI/FS SCOPING}

\section{Step $1 \quad$ Start.}

Step 2, 2a Part 300.430 (b) of the NCP provides guidance on RI/FS scoping. A detailed diagram of the scoping process is presented in Figure 2-1 of earlier EPA (1988a) guidance. Project ecologists should contact appropriate professionals of federal and state agencies with special knowledge of or legal responsibility for ecological resources. Regional offices of the EPA, the FWS, and state agencies also can provide information on groups or individuals with special interest or technical expertise with respect to biological resources in the area.

Step 3, 3a A determination by professional ecologists on the adequacy of existing ecological information should be made early in the RL/FS scoping process. Appropriate field data collection may be warranted to adequately characterize the site. The intended use of ecological data will dictate the number of data samples collected, sample location, and species sampled. In many cases

Preliminary studies to identify and specify ecological assessment objectives include site visits, examination of aerial or satellite photographs, evaluation of information from local experts, and limited ecological data collection. Preliminary studies may reveal potential exposure pathways, receptors, and previously unobserved toxic effects or site habitats (EPA 1989c, 1992a). professional judgment will be necessary to determine ecological data needs when no previous site-specific data are available.

Once preliminary ecological data have been collected, the ecologists responsible for developing the ecological work plan may want to discuss findings with EPA biologists and members of the BTAG to obtain input beneficial to the ecological risk assessment process. The BTAG may help determine target species to be evaluated and data needs for the risk assessment (see Appendix A, Section A.3).

Step 4 Planning for detailed ecological data requirements to be defined in the site ecological work plan should be initiated at this stage. The DOE ERPM and project ecologists should contact state and federal agencies having responsibility for implementing project ARARs, to identify additional ecological data needed to characterize the existing site. 
Step 5 Determine from interviews what ecological resources that public groups and individual members of the general public feel are important and should be identified in the community relations plan (EPA 1988a). Recreational species (e.g., important game fish and wildlife species commonly hunted) will often be of interest to the public and special interest groups.

\section{References}

EPA, 1988a. Guidance for Conducting Remedial Investigations and Feasibility Studies under CERCLA, Interim Final, report EPA/540/G-89/004, OSWER Directive 9335.3-01, U.S. Environmental Protection Agency, Washington, D.C.

EPA, 1989c. Risk Assessment Guidance for Superfund - Vol. II, Environmental Evaluation Manual, report EPA/540/89/001, U.S. Environmental Protection Agency, Washington, D.C.

EPA, 1992a. Framework for Ecological Risk Assessment, report EPA/630/R-92/001, U.S. Environmental Protection Agency, Washington, D.C. 


\section{MODULE 6:}

\section{DEVELOP SITE ECOLOGICAL CONCEPTUAL MODEL}

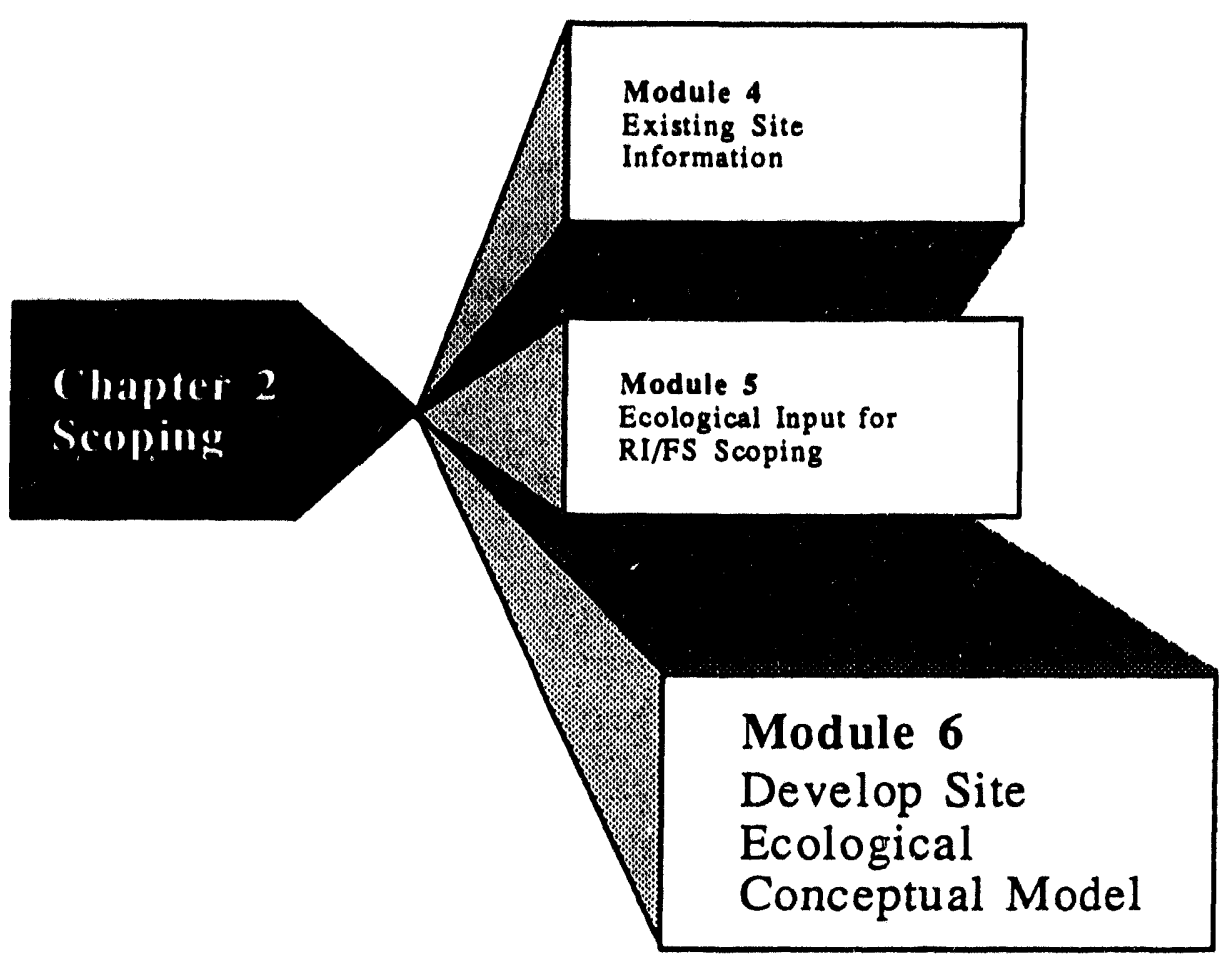




\section{Module 6: Develop Site Fcological Conceptual Model}

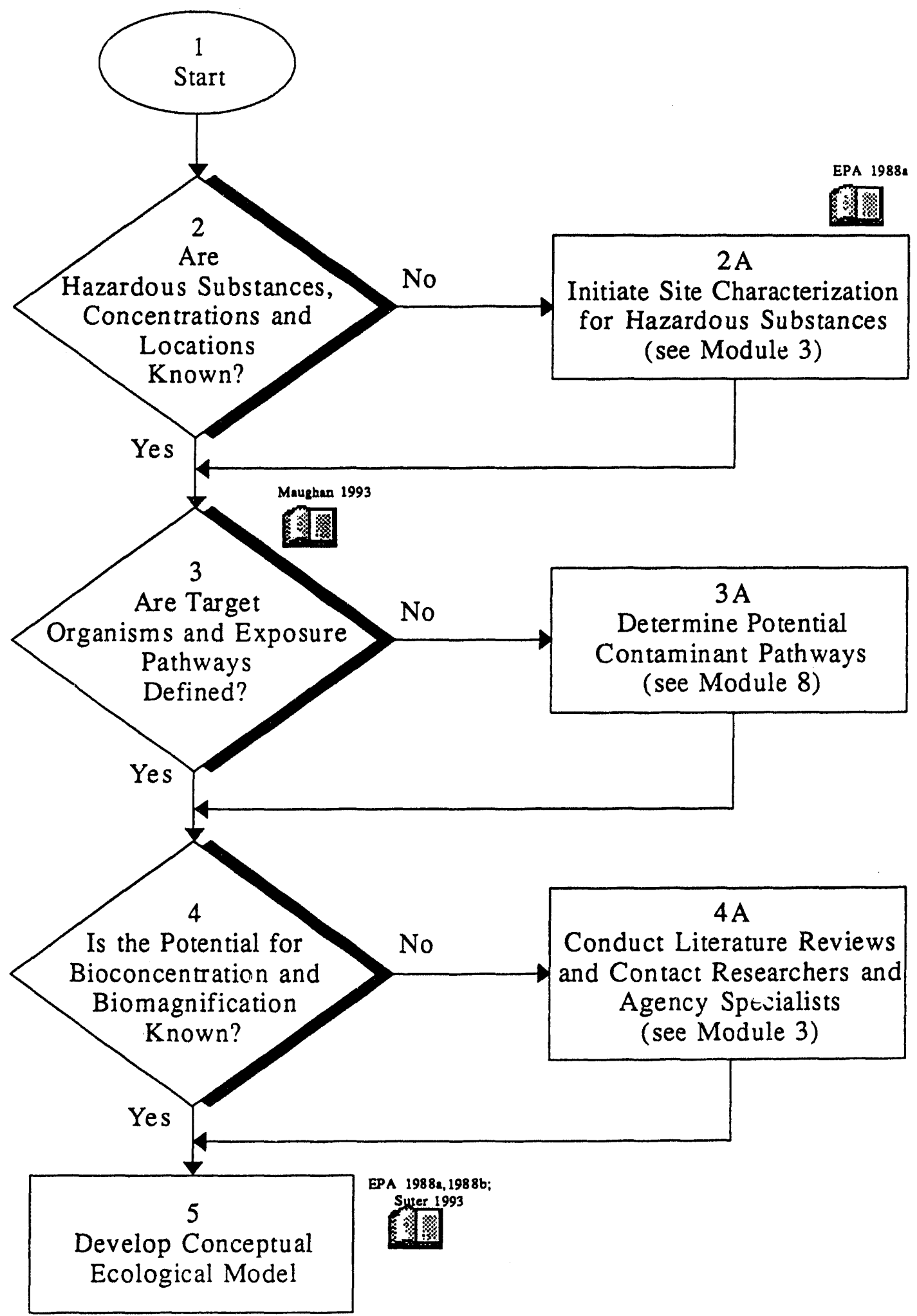




\section{MODULE 6: DEVELOP SITE ECOLOGICAL CONCEPTUAL MODEL}

\section{Step 1 Start.}

Step 2, 2a A conceptual site model should be developed by project engineering and environmental staff on the basis of information obtained pursuant to NCP Part $300.430 \mathrm{~b}(1)$. The DOE CERCLA environmental reference book includes the NCP regulations that pertain to site characterization and data needs for developing a site conceptual model (ORNL 1993). Preliminary information on hazardous substances present at the site must be known. Additionally, the locations and concentrations of hazardous substances at the site must be generally understood to proceed with the development of a site conceptual model. If this information is not known, Steps 2a and 3a of Module 3 will need to be undertaken.

Step 3, 3a Ecological data should be adequate to define target organisms and exposure pathways through the various trophic levels. An exposure pathway is the link between a contaminant source and a receptor (EPA 1991b) If this information is not known, Steps 3 through 5 of Module 8 will need to be undertaken.

In cases where site-specific ecological data are unavailable for the contaminants and habitat/community types in question, comparable sites with

Receptor Species or Target Organisms include: (1) species considered essential to, or indicative of, healthy functioning of habitats (e.g., stream invertebrates); (2) rare, endangered, or threatened species on or near the site; and (3) species protected under federal or state law (e.g., Migratory Bird Treaty Act, Marine Mammal Protection Act) (EPA 1991b). Receptor species may also be chosen to represent a particular guild (i.e., group of organisms with similar habitat and/or feeding requirements). For example, a common shrew species would be selected as a representative of small, insectivorous mammals.

the same or similar contaminants can be used in developing the model. The appropriateness of using ecological data from supposedly comparable sites can be a major point of disagreement among ecologists and engineers or project administrators and among DOE, the EPA, and state reviewers faced with making project decisions in a timely, efficient manner.

Step 4, 4a Determinations of the potential for bioconcentration and biomagnification within the ecological resources of the site can be made on the basis of literature and site-specific laboratory and field testing of the target organisms in question (see Appendix A, Sections A.3.4 and A.4.1.4). In some cases, little (if any) 
data may exist on contaminant effects to the target species, necessitating the use of data on similar or related species. Refer also to Step 4a of Module 3.

Step 5 The purpose of the conceptual site model is to focus the RI/FS process and to provide a basis for the initial risk assessment (i.e., baseline risk assessment). A conceptual ecological model should be developed on the basis of assumptions of current source of media contamination (e.g., soils and sediments), release mechanisms (e.g., groundwater,

Site Conceptual Model includes source-pathway-receptor diagrams and descriptive text. It helps to define and describe the following: (1) nature and extent of contamination; (2) physical setting of the site; (3) geology, hydrology, and geochemistry; (4) fate and transport mechanisms; (5) contaminant pathways, and (6) receptors. surface runoff), environmental transport medium (e.g., direct contact, air, groundwater, surface water), and potential exposure routes (i.e., ingestion, inhalation, and/or dermal contact) to biotic receptors. Figure 6.1 depicts a simplified conceptual site ecological model diagram that would be applicable to a contaminated waste site. The conceptual model could become more complex depending on types and extent of habitats that are contaminated and as the "food web" increases in complexity (see Appendix A, Section A.3.2).

Once the ecological conceptual model is developed, work can commence on developing an ecological work plan (see Modules 9 and 10), the specific sampling program (see Modules 12 and 13), and ecological data needs for the baseline risk assessment (see Module 15). 


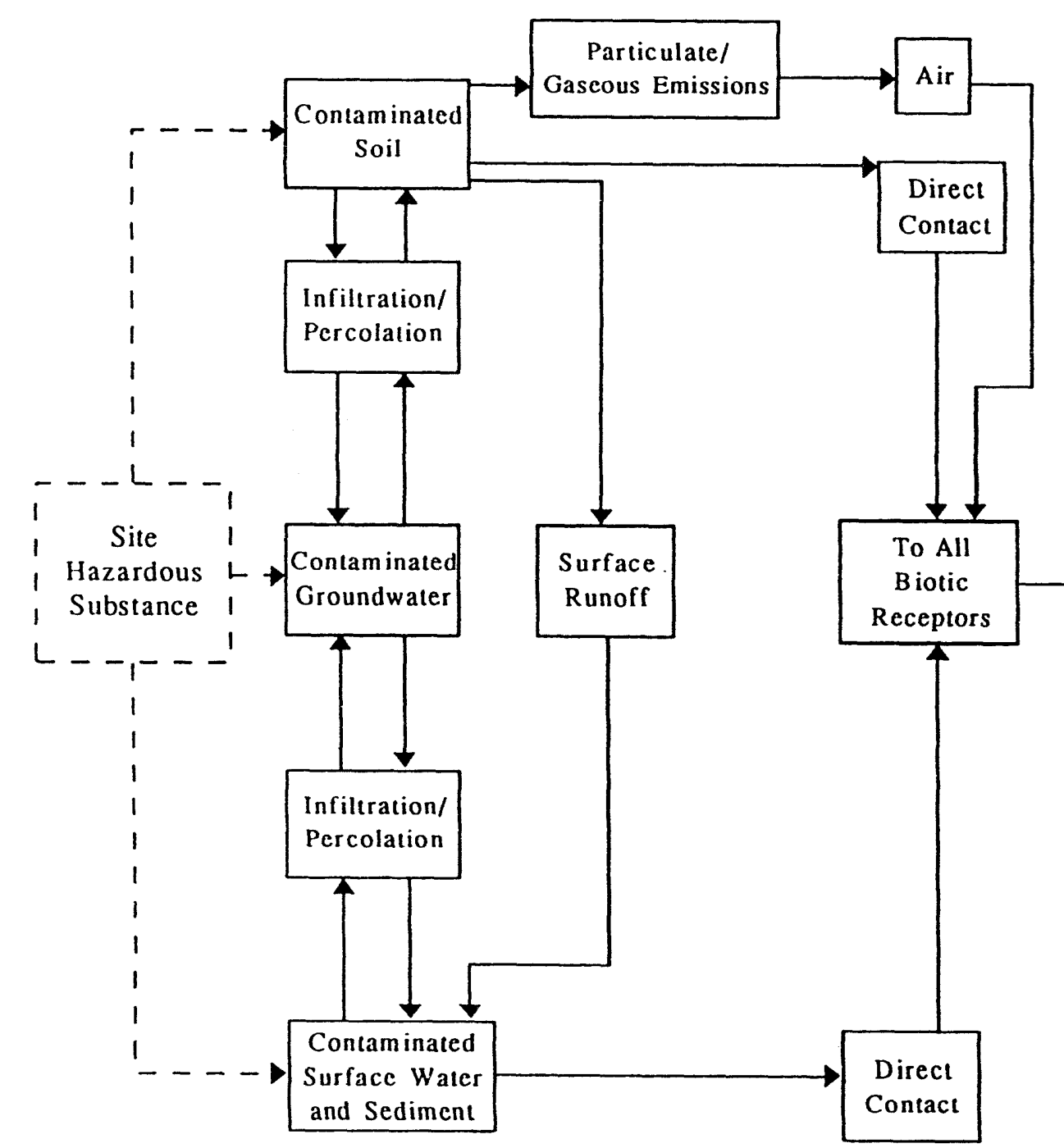

FIGURE 6.1 Example of a Conceptual Site Ecological Model 


\section{References}

EPA, 1988a. Guidance for Conducting Remedial Investigations and Feasibility Studies under CERCLA, Interim Final, report EPA/540/G-89/004, OSWER Directive 9335.3-01, U.S. Environmental Protection Agency, Washington, D.C.

EPA, 1989d. Rapid Bioassessment Protocols for Use in Streams and Rivers: Benthic Macroinvertebrates and Fish, report EPA/444/4-89-001, J.A. Plafkin (ed), U.S. Environmental Protection Agency, Washington, D.C.

EPA, 1991b. ECO Update, Ecological Assessment of Superfund Sites: An Overview, U.S. Environmental Protection Agency, Office of Solid Waste and Emergency Response, Intermittent Bulletin 1(2):1-8, Washington, D.C.

Maughan, J.T., 1993. Ecological Assessment of Hazardous Waste Sites. Van Nostrand Reinhold, New York.

ORNL, 1993. Environmental Guidance Program Reference Book, Comprehensive Environmental Response, Compensation, and Liability Act, report ORNL/M-2261, Oak Ridge National Laboratory, Oak Ridge, Tenn.

Suter, G.W., II, 1993. Ecological Risk Assessment. Lewis Publishers, Chelsea, Mich. 


\section{CHAPTER 3}

\section{Initial Evaluation}

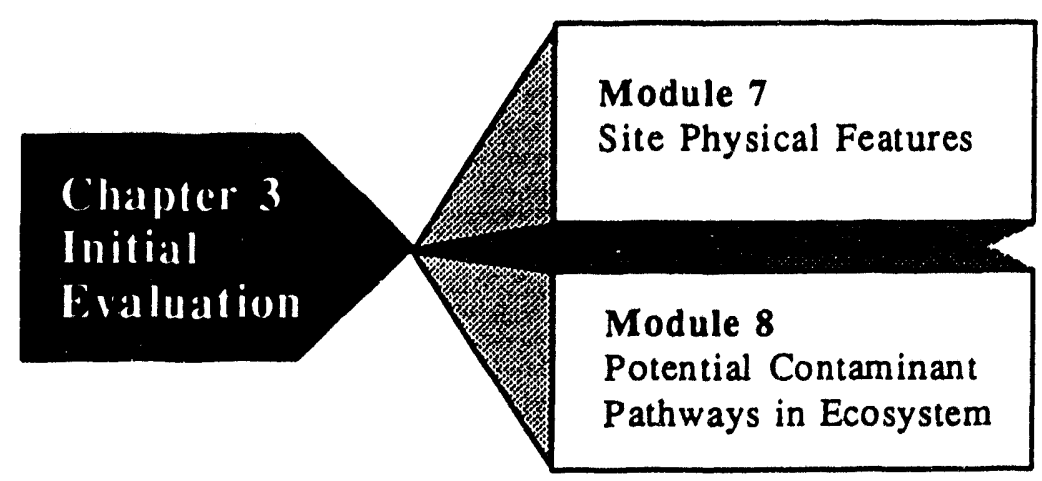

\section{CONTENTS}

Module 7: Site Physical Features $\ldots \ldots \ldots \ldots \ldots \ldots \ldots \ldots \ldots \ldots$ II-43

Module 8: Potential Contaminant Pathways in Ecosystem . . . . . . . . . . II-47 


\section{CHAPTER 3: INITIAL EVALUATION}

The ecological work plan should include a section describing important site physical features, which aids in understanding the potential for transport of contaminants both onand off-site. Groundwater and surface water pathways are important considerations in planning tasks to determine the ecological effects of contaminants. The movement of a contaminant from a location in or adjacent to a surface water body is important information in planning sampling of such groups as benthic invertebrates or of fish habitats. Locations of contaminants with respect to topographic features such as slopes, ridges, or depressions are important at sites having surface contamination. Topographic features provide insight on the potential extent of contamination by hazardous substances from a point source.

The ecological work plan should only contain information on physical features relevant to ecological data collection and analytical tasks described later in the work plan. More detailed information on the physical features of the site would be included in the overall RI/FS work plan.

Understanding potential contaminant pathways to ecological receptors requires a thorough understanding of air, water (surface and groundwater), sediments, and soil transport mechanisms. Information obtained in scoping (see Module 5) should assist the DOE ERPM in determining the need for additional ecological field studies to better define potential pathways. For example, members of the public may know of existing areas of contamination or areas believed to be contaminated relative to recreationally important species or sensitive plant communities. This input could serve as guidance for initial off-site sampling locations.

As part of the initial evaluation, project ecologists should become familiar with recent literature on ecological risk assessment (Bartell et al. 1992; Maughan 1993; Suter 1993). Two themes are found in these documents relative to conducting acceptable ecological risk assessments. First, the ecological team must properly define the ecological endpoints, realizing the normal variation in the ecosystem, based on a thorough site characterization early in the risk assessment process. The second theme centers on the need for model use in estimating exposure assessment and contaminant transfer within the ecosystem. This concept often requires a phased approach to field sampling and toxicity testing.

In addition to the above considerations, project ecologists must develop a good understanding of existing ecosystems to address such issues as natural variability at the CERCLA site and/or reference site and appropriate statistical tests for the species being analyzed. For example, plant communities consisting of a few species, such as a short grass prairie or agricultural system, may vary little when sampling for primary production or species diversity; whereas sampling of deciduous forest plant communities undergoing secondary succession may result in highly variable data, depending on location and time of sampling. Understanding normal seasonal variation and within-season variation is important in structuring sampling design. 


\section{References}

Bartell, S.M., et al. (eds.), 1992. Ecological Risk Estimation. Lewis Publishers, Chelsea, Mich.

Maughan, J.T., 1993. Ecological Assessment of Hazardous Waste Sites. Van Nostrand Reinhold, New York.

Suter, G.W., II, 1993. Ecological Risk Assessment. Lewis Publishers, Chelsea, Mich. 


\section{MODULE 7:}

\section{SITE PHYSICAL FEATURES}

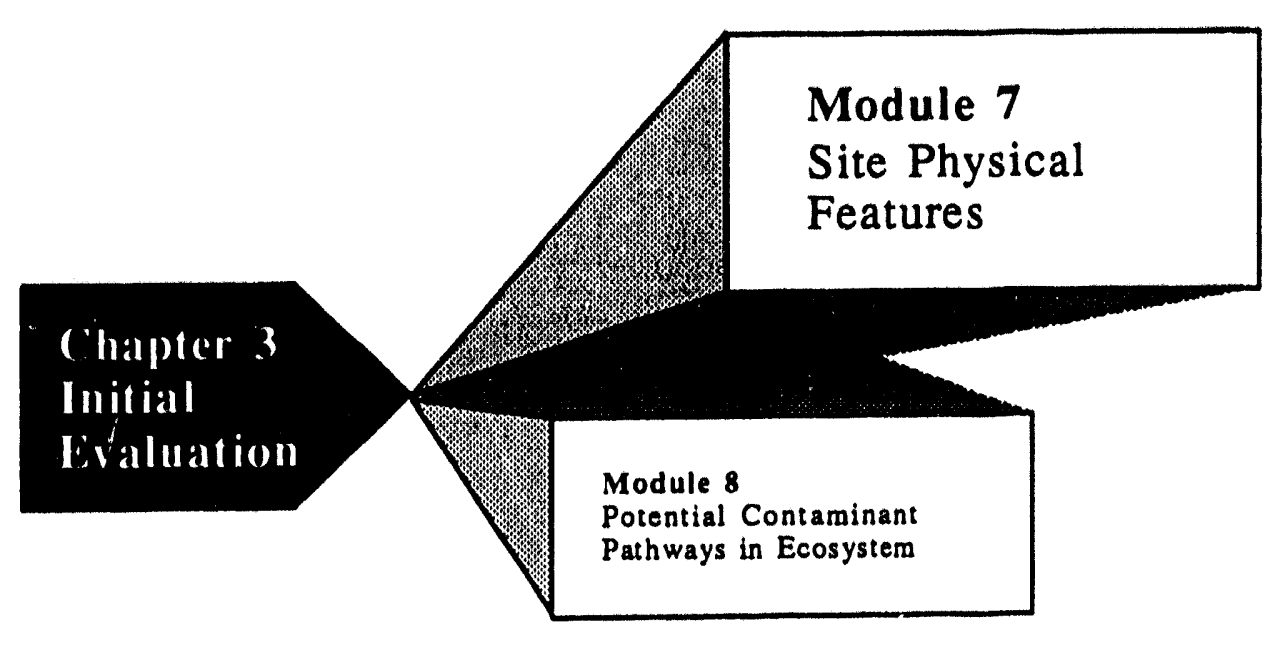




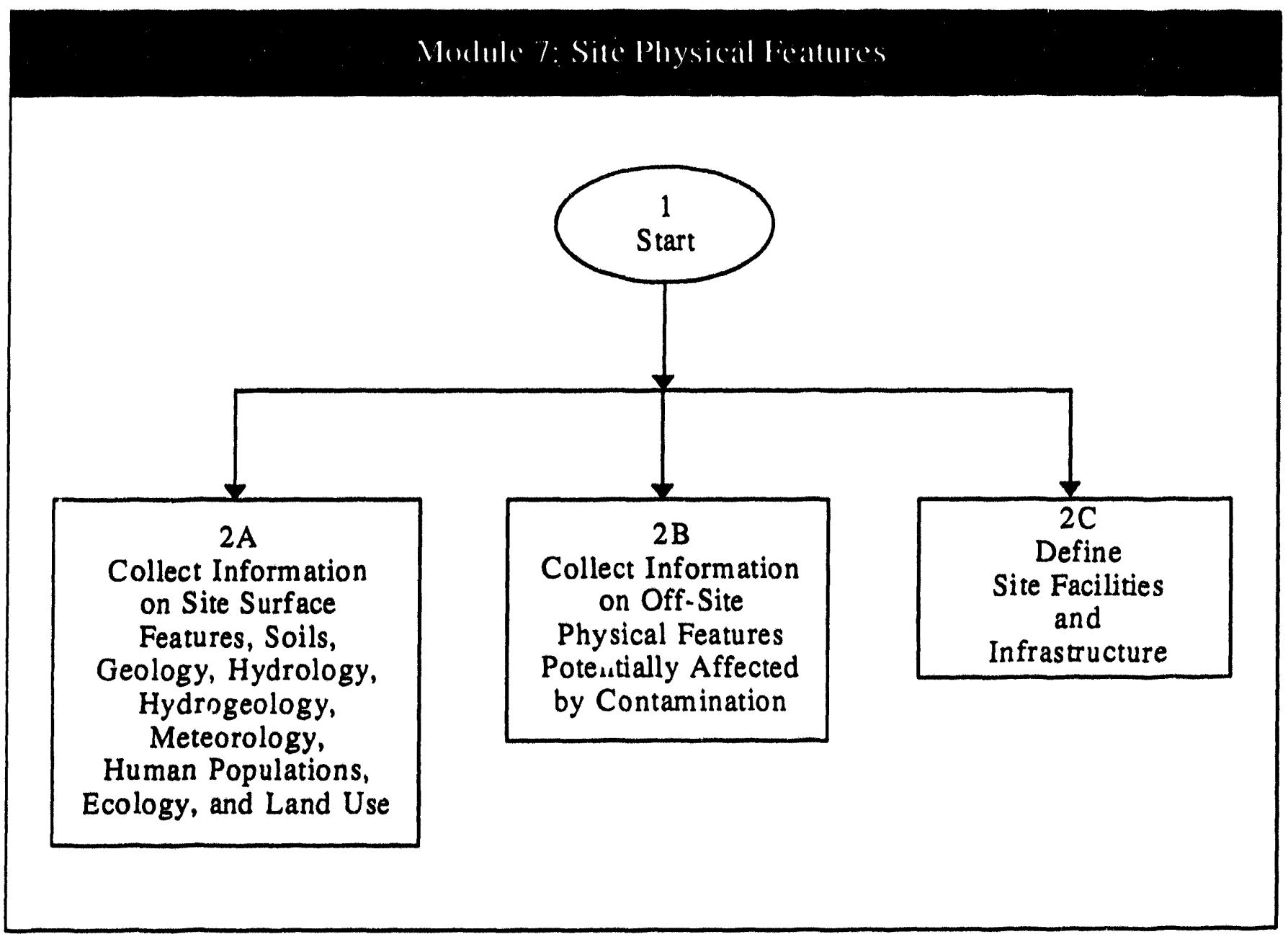




\section{MODULE 7: SITE PHYSICAL FEATURES}

Step $1 \quad$ Start.

Step 2a, 2b Developing an accurate description of site physical features (i.e., topography, geographic setting, locations of streams and surface waters, depth to groundwater, and spatial distribution of ecological communities), and facilities/ infrastructure is paramount to setting the baseline for conducting a risk assessment. Guidance on conducting remedial investigations at CERCLA sites (EPA 1988a) should be reviewed by all technical specialists involved in site characterization planning. This review would inform the project ecologist of the overall RI/FS process and provide an overview of where in the process ecological input is needed. Activities in Steps $2 a, 2 b$, and $2 c$ should be conducted in parallel. Both on- and off-site physical features currently or potentially affected by the unremediated CERCLA site, or that may be affected by remediation, require accurate definition (see Appendix A, Sections A.1.2 and A.1.3).

Step 2c Existing site facilities (including waste impoundments, landfills, and historic facility locations) and their contribution to site contamination require careful delineation during site characterization (see Appendix A, Section A.1.1). Full descriptions of existing utility and transportation systems must be developed and provided to the decision maker responsible for logistical aspects of remedial alternatives development.

Waste impoundments and landfills from past research or production activities and abandoned facilities often contribute to soil, surface water, and groundwater contamination. Habitats and biota in and around these areas should be carefully analyzed to determine (1) current contamination levels in the abiotic and biotic components of the site ecosystems, and (2) the potential for biomagnification within the food chain if the site were to continue in an unremediated condition.

The locations, types, and conditions of existing roads are important considerations in planning the logistics of transporting contaminants from the site. This information will be useful in determining the extent to which roads and bridges will need to be upgraded in order to carry out the remedial actions. The need for road upgrades or siting of new off-site roads to conduct remediation should also be determined. 


\section{References}

EPA, 1988a. Guidance for Conducting Remedial Investigations and Feasibility Studies under CERCLA, Interim Final, report EPA/540/G-89/004, OSWER Directive 9335.3-01, U.S. Environmental Protection Agency, Washington, D.C. 
MODULE 8:

POTENTIAL CONTAMINANT PATHWAYS IN ECOSYSTEM

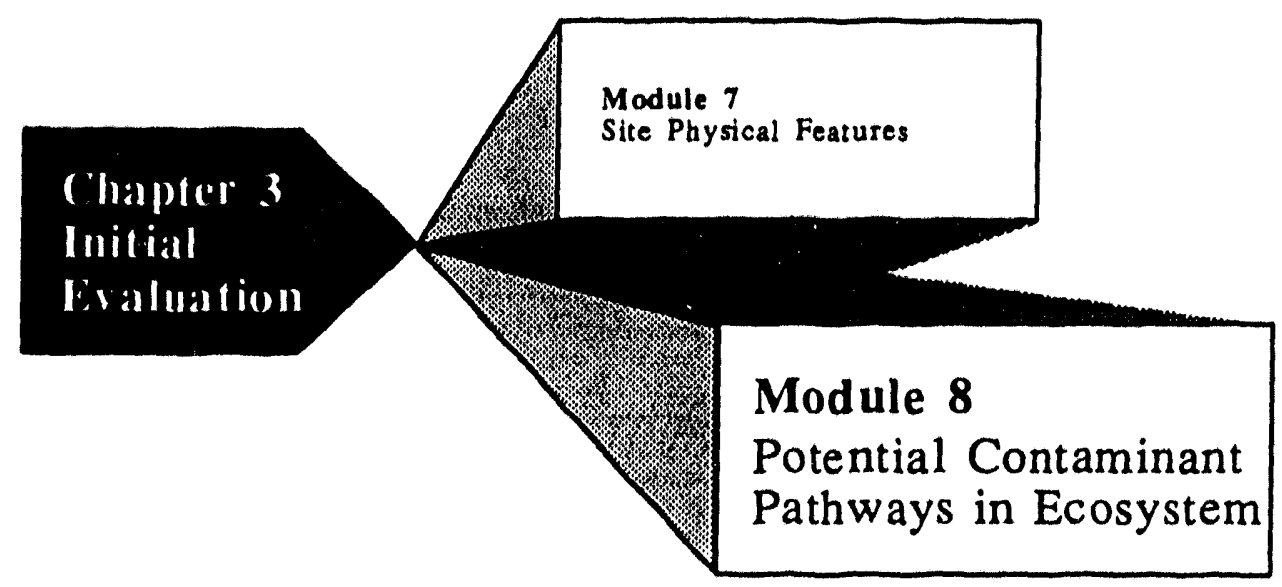




\section{Module 8: Potential Contaminant Pathways in Ecosystem}

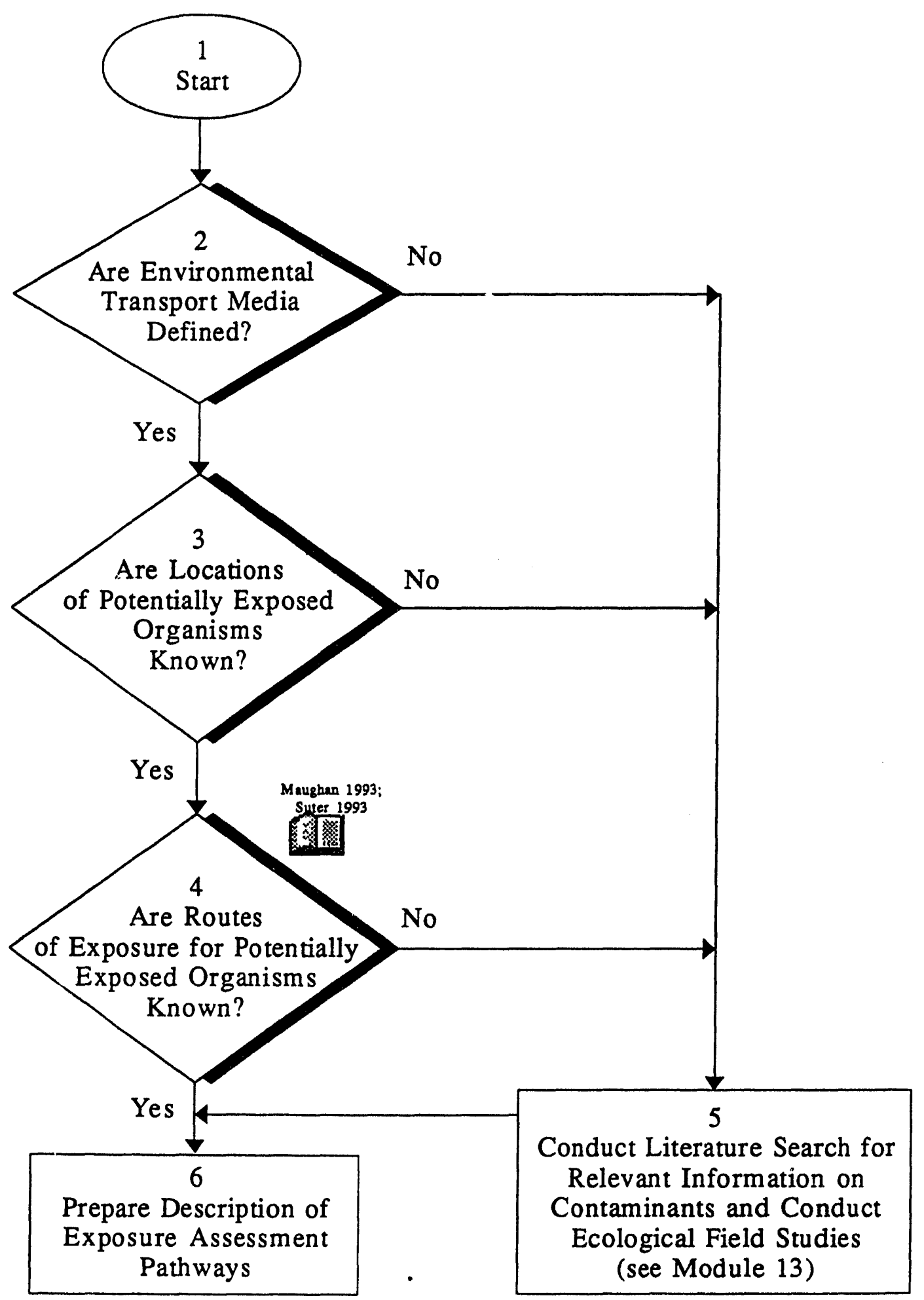




\section{MODULE 8: POTENTIAL CONTAMINANT PATHWAYS IN ECOSYSTEM}

\section{Step 1 Start.}

Step 2 Definition of the transport media may require determination of contaminant movement by air, surface water, and groundwater, especially when hazardous substances are deposited or released on the soil surface. The contaminant transport between media and biota and among trophic levels identified in the ecological conceptual model (see Module 6) should be determined to more accurately define both transport pathways and contaminant fate (see Appendix A, Section A.3.2).

The work plan should specify the assessment of contaminant exposure, using fate and transport models. Fate concerns the ultimate chemical disposition of a contaminant (e.g., remaining stable, undergoing photo-degradation, or combining with another substance). Transport (or migration) refers to the movement of a contaminant from one medium to another, from one location to another within the same medium, or into biota (EPA 1992b).

Step 3 Actual or potential exposure locations on- and off-site should be identified once the transport media are defined.

Step 4 Inhalation, ingestion, and dermal contact are exposure routes to be evaluated for contaminants at the CERCLA waste site. Suter (1993) provides examples of exposure routes and a discussion of toxicokinetic models to arrive at the internal doses to organisms exposed to a contaminant. Contaminant uptake can be predominantly from exposure along a single pathway or along multiple pathways. For example, in the latter situation, kit foxes at a semiarid oil field site can be exposed to contaminants by dermal exposure to drilling muds, soil ingestion, ingestion of contaminated prey, ingestion of drilling brines, and inhalation (Suter 1993). Multiple-route exposures to hazardous substances are shown in the diagram of the conceptual model (see Module 6). The most complex exposure routes occur in animals that utilize both terrestrial and aquatic habitats, particularly when soil, water, and sediments are all contaminated.

Step 5 A thorough literature review will assist the DOE ERPM in defining potential exposure pathways from the hazardous substance source to the target organism or population (see Appendix A, Section A.3.4). Many publications within the past 10-15 years have reported biological effects from exposure to environmental contaminants. Although it is not the intent of this document to review the literature on contaminant effects, the following guidance is provided as a starting point. While many scientific journals typically have included articles on environmental effects from exposure to contaminants, two notable examples are the Bulletin of Environmental Contamination and Toxicology and Environmental 
Toxicology and Chemistry. Also, project ecologists should become familiar with the contaminant hazard review series on wildlife prepared by the FWS. As of June 1992, 24 reports in the series had been published (see Module 10 for examples of recent reports). Also, Peterle (1991) provides a recent overview of environmental pollutants affecting wildlife. Newman and McIntosh (1991) describe conceptual bases for understanding the fate of various metals in the environment, with an emphasis on toxic ecological effects.

Step 6 Descriptions of potential exposure pathways will assist the DOE ERPM in further defining field sample collections and laboratory toxicity tests. The ecological work plan should include a description of the potential contaminant migration and exposure pathways within the ecosystems likely to be affected. Suter (1993) addresses potential contaminant pathways within ecosystems, and Maughan (1993) suggests a process called "transfer pathway analysis" for determining species affected at waste sites. This process is iterative, consisting of increasing the level of detailed analyses as one proceeds with the analysis. Major steps in the transfer pathway analysis include (1) site inspection and reconnaissance, (2) species groupings by guilds, (3) identification of potential intake pathways, (4) selection of important receptor species, and (5) further refinement of contaminant transfer through intensive laboratory or field testing of a limited number of receptor species. Results are then incorporated into overall remediation alternatives evaluations.

\section{References}

EPA, 1992b. ECO Update, Developing a Work Scope for Ecological Assessments. U.S. Environmental Protection Agency, Office of Solid Waste and Emergency Response, Intermittent Bulletin 1(4):1-15., Washington, D.C.

Maughan, J.T., 1993. Ecological Assessment of Hazardous Waste Sites. Van Nostrand Reinhold, New York.

Newman, M.C., and A.W. McIntosh (eds.), 1991. Metal Ecotoxicology, Concepts and Applications. Lewis Publishers, Inc., Chelsea, Mich.

Peterle, T.e., 1991. Wildlife Toxicology. Van Nostrand Reinhold, New York.

Suter, G.W., II, 1993. Ecological Risk Assessment. Lewis Publishers, Chelsea, Mich. 


\section{CHAPTER 4}

\section{Work Plan Rationale}

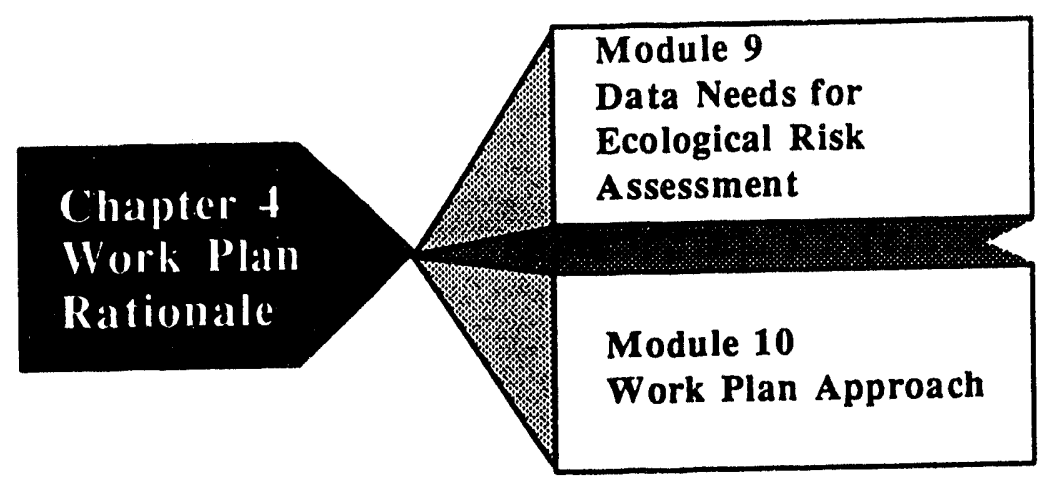

\section{CONTENTS}

Module 9: Data Needs for Ecological Risk Assessment $\ldots \ldots \ldots \ldots \ldots \ldots \ldots$ II-55

Module 10: Work Plan Approach $\ldots \ldots \ldots \ldots \ldots \ldots \ldots \ldots \ldots$ II -63 


\section{CHAPTER 4: WORK PLAN RATIONALE}

Data needed to fully understand existing ecological resources should be defined and included in the rationale section of the ecological work plan. The rationale section should also explain and justify the approach to be taken in collecting ecological data. The following aspects of the approach should be included when applicable:

- Reference areas - Reference areas are generally uncontaminated and serve as a basis for comparison with the contaminated ecological habitat at the CERCLA site. Reference areas could be useful for certain streams or rivers and for terrestrial ecosystems where the contaminants are "point sources" in their spatial distribution. Reference areas can provide information on species composition and variation that is useful in setting revegetation and other reclamation goals for remediated sites.

- Ecological field surveys - Surveys of biotic communities will be used to characterize the biota and habitats both on- and off-site. Surveys of reference areas and contaminated areas should be conducted with the same techniques and at the same level of detail to ensure valid comparisons of data.

- Surrogate species for laboratory tests - Use of surrogate species tests is important when the receptor species have not been studied relative to the contaminants being evaluated or when species are precluded from study due to regulatory protection (e.g., bald eagle). Use of taxonomically similar species for laboratory tests will provide useful information on the potential for bioaccumulation and/or chronic and lethal effects to individual organisms on site.

- In situ testing - Tests of an organism's responses to contaminants can be conducted with techniques such as exposing a receptor species in confined areas affected by contaminants (e.g., caged areas downstream of a point source in a stream), monitoring animal habitat use in the immediate vicinity of the contaminants, or conducting vegetation trials on contaminated soils of varying concentration. In-situ testing has disadvantages relative to controlling environmental variables but is advantageous in the sense that test organisms are exposed to contaminants in a more natural or "typical" environment.

- Toxicity tests - Toxicity tests are generally conducted in the laboratory and are used to determine impacts on individual organisms in terms of exposure to varying concentrations of a single or multiple contaminants under controlled conditions. 


\section{MODULE 9:}

\section{DATA NEEDS FOR ECOLOGICAL RISK ASSESSMENT}

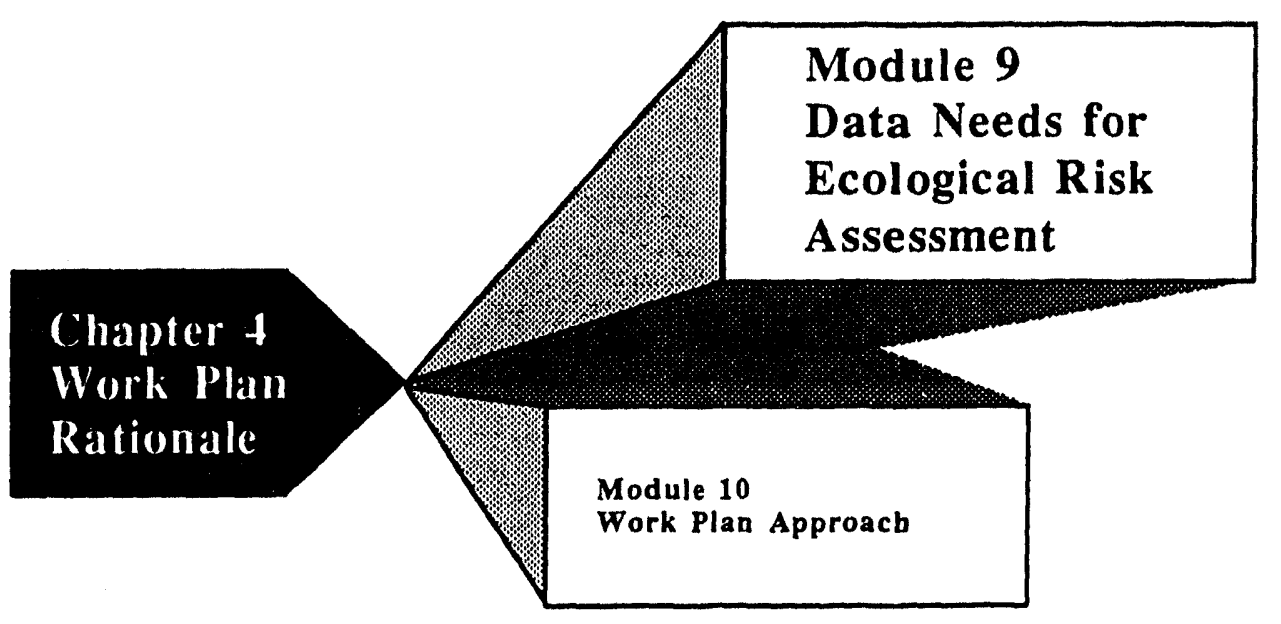




\section{Module 9: Data Needs for Ecological Risk Assessment}

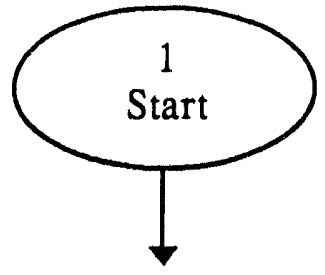

Ecological Data Needs

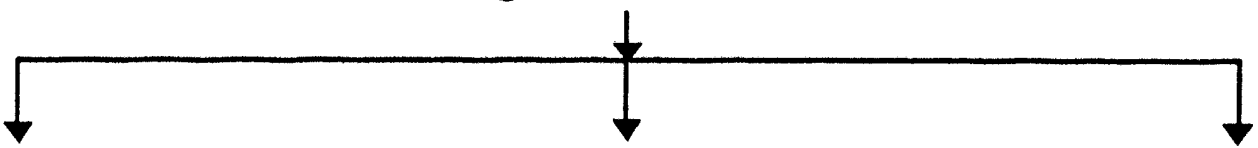

Biota and Habitat Types

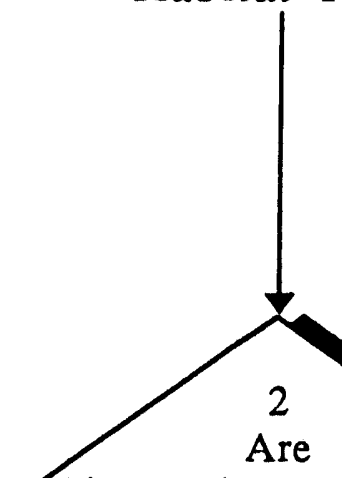

Biota and Habitat Types for the Site and Vicinity

\section{Defined?}

State Protected Species; Sensitive/Unique Communities and Habitats

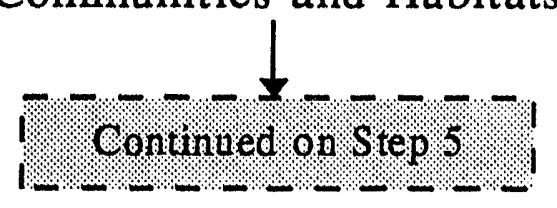

\section{$2 \mathrm{~A}$}

Federal Protected Species

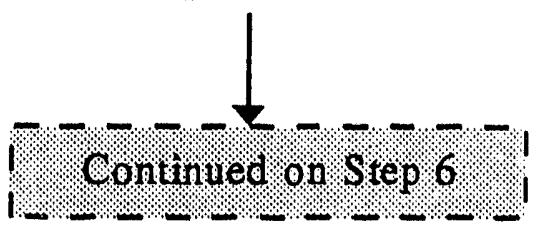

Collect Relevant Maps and Conduct Field Surveys to Define Communities and Habitat Types

$3 \mathrm{~A}$

Determine Hazard

Distribution

(see Modules 3 and 8)

in Biota

or Habitats?

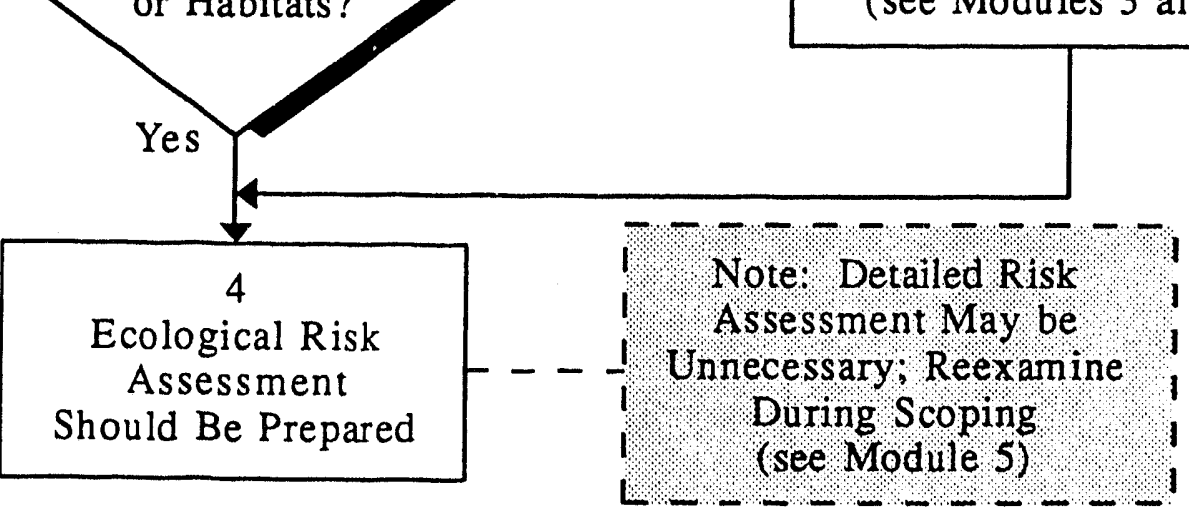




\section{MODULE 9: DATA NEEDS FOR ECOLOGICAL RISK ASSESSMENT}

Step $1 \quad$ Start.

Step 2, 2a An inventory of site ecological data should be compiled. This information will allow a determination of data adequacy (e.g., species studies and abundance of data by season or year) before proceeding with subsequent assessment tasks. Plant communities should be defined on a site map relative to known locations of hazardous substances. Qualitative and quantitative descriptions should be prepared. Typical information needed to characterize communities on-site and in the site vicinity include species lists by community type, percent cover, diversity indices (where appropriate), production data on important species, and population dynamics of various wildlife species (see Appendix A, Sections A.4.1.1 and A.4.1.3).

Step 3, 3a Known locations of hazardous substances should be identified with respect to important biota and habitat types. If inadequate data exist, additional studies may be warranted to determine hazard distribution (Appendix A, Sections A.1.2 and A.1.3).

Step 4 If the site is devoid of vegetation, which is typical of an industrialized site, and provides essentially no habitat for wildlife where the hazardous substance occurs or to where it could migrate without remediation in the future, a detailed ecological risk assessment may be unnecessary. A final decision on the need for a detailed ecological risk assessment should not be made until scoping has been completed and interactions have occurred between DOE and agencies with legal responsibility for ecological resources. 


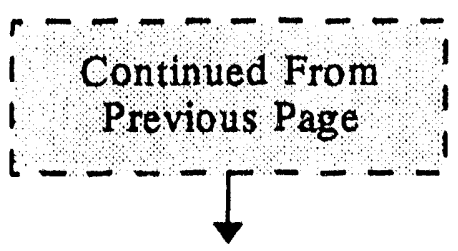

State Protected Species;

Sensitive/Unique

Communities and Habitats

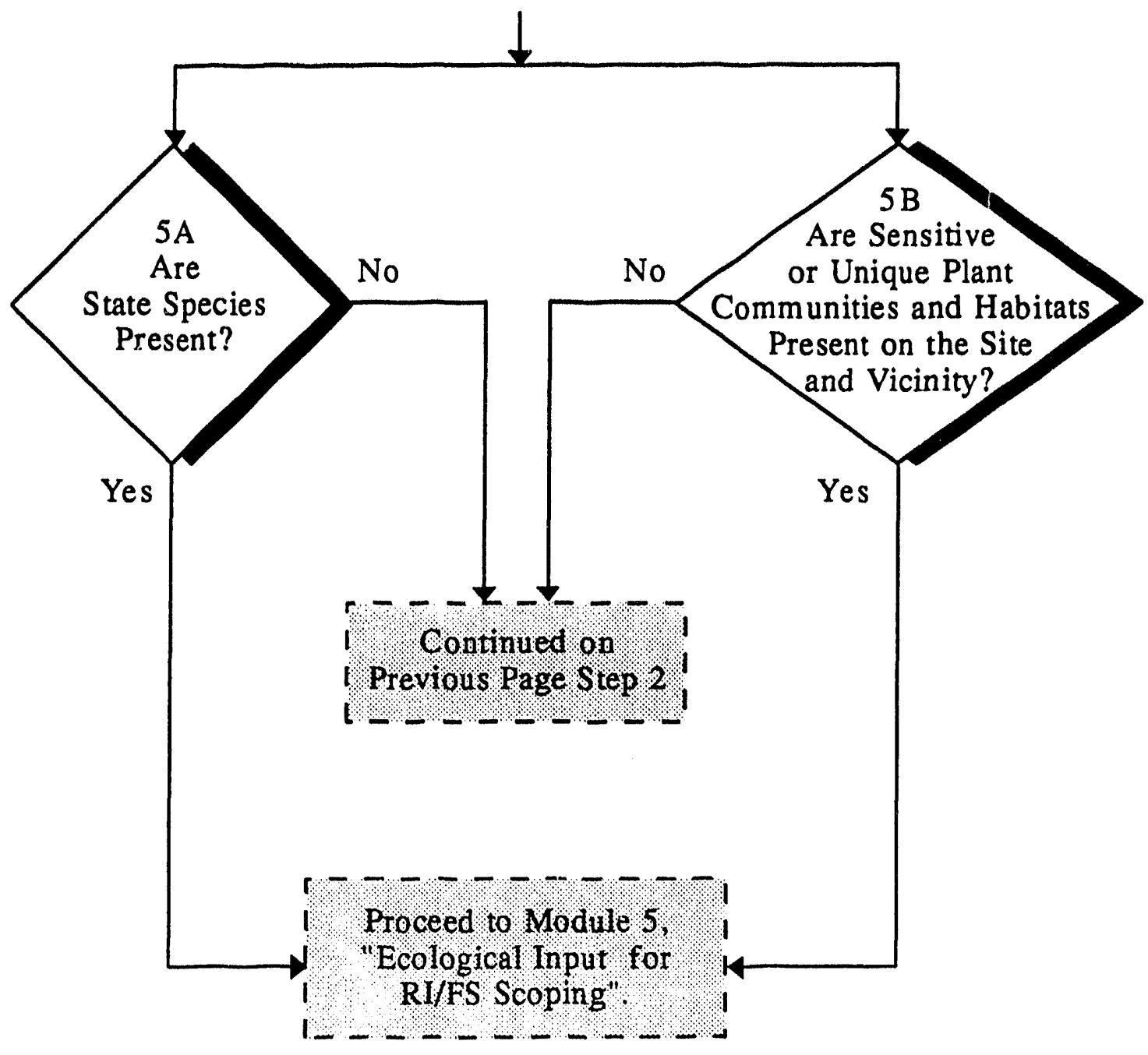


Step 5a, 5b Qualitative and quantitative descriptions should be prepared and spatial distribution data collected for sensitive/unique plant communities or habitats on the site (see Appendix A, Section A.1.3) and in adjacent communities likely to be impacted by the hazardous substances in question. The appropriate state environmental or natural resource agency (e.g., Department of Sensitive environments require special attention at a particular site. These environments include (1) those associated with federal or state laws (e.g., wetland, critical habitats for listed species); (2) unique or unusual habitats (e.g., prairie remnants, springs); (3) those necessary for continued propagation of a key species (e.g., essential food, nesting, spawning or rearing sites) (EPA $1989 \mathrm{c}$ ). Conservation) can provide information on state-listed threatened and endangered species. Sensitive plant communities are often afforded protection by states. The occurrence or characterization of valuable communities or habitats may be difficult to determine on the basis of available information.

In determining ecological data needs for the RI/FS, the DOE ERPM and project ecologist should use, as guidance, a listing of sensitive environments defined by the EPA (see Appendix D). The presence of these sensitive environments along the migration pathways from the contaminated site was used as a criterion in evaluating the site originally for inclusion on the EPA's NPL.

Making a professional judgment that an existing plant community or habitat type is valuable may be a controversial point between ecologists and engineers or planners faced with decisions on developing remediation alternatives. Habitat importance will be site-specific and will depend upon such factors as (1) the species native to an area and their significance, (2) the availability and quality of substitute habitats, (3) surrounding land use and management, and (4) the value (e.g., economic, recreational or aesthetic) placed on such habitats by local residents or special interest groups (EPA 1989c). 


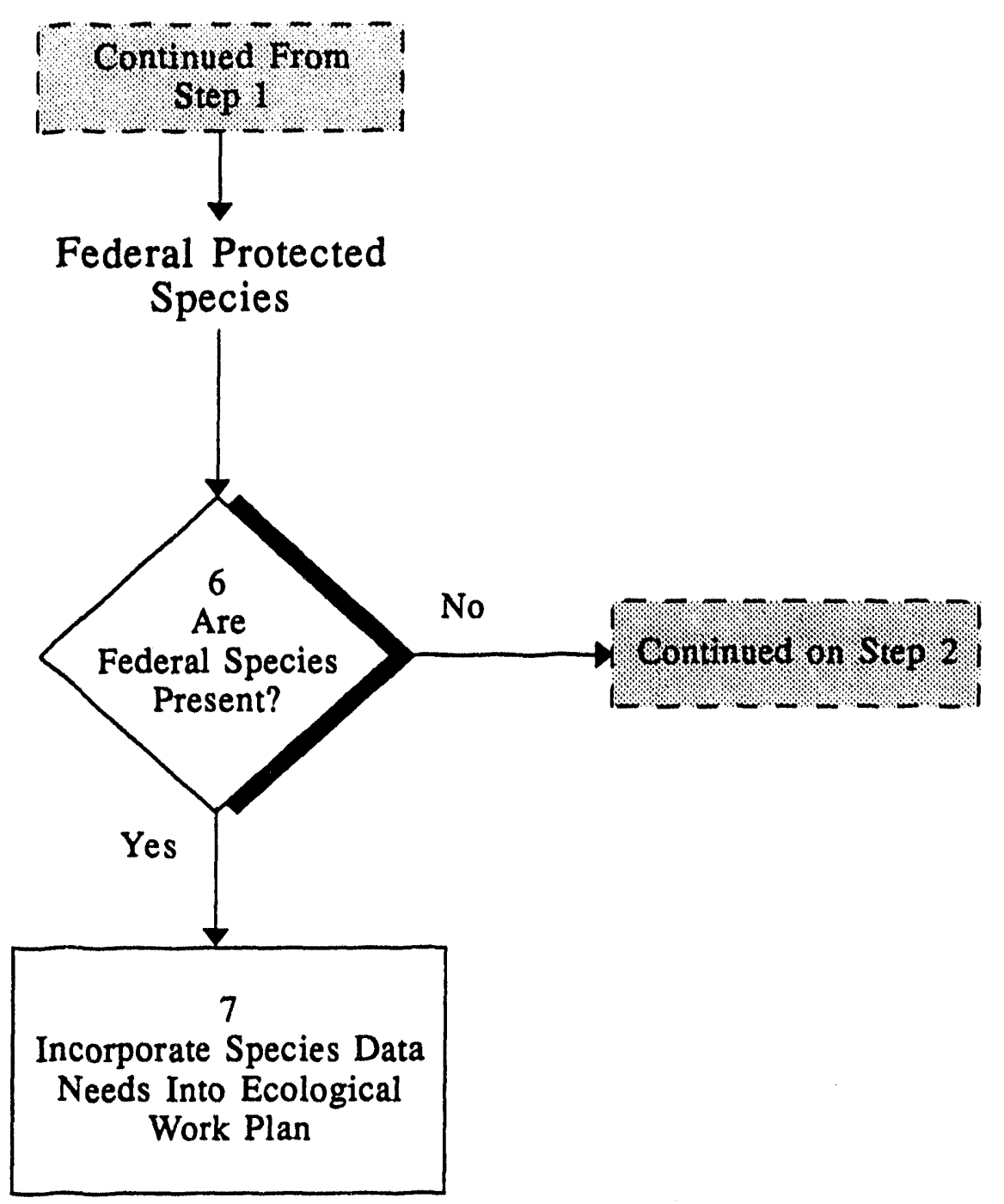


Step 6

Step 7
The FWS and appropriate state environmental or natural resource agencies can provide preliminary information on federally listed threatened and endangered species and/or designated critical habitats of the site area.

If federally protected species are present, the ERPM should determine what data would be required to conduct an ecological risk assessment and incorporate such needs into the ecological work plan. A biological assessment would be prepared as part of the evaluation and comparison of remedial action alternatives (see Module 16). The biological assessment would examine impacts to federally protected species not only for each remedial action alternative, but also for the no-action alternative. All alternatives will be addressed in the FS. The biological assessment will be submitted to EPA along with the project FS reports.

The following discussion covers ecological data needs for federally protected species and gives an overview of FWS and DOE responsibilities in evaluating impacts. The discussion is included here rather than in Module 16 to inform the ERPM, project ecologists, and other users of the typical data needs and review process to be expected.

The Endangered Species Act requires the preparation of a biological assessment if federally endangered or threatened species inhabit or visit the CERCLA site or are located in areas adjacent to the site likely to be impacted by hazardous substances released at the site. Candidate species (C2 designation) for federal listing should also be evaluated for inclusion in the biological assessment. Data needs should be identified and factored in the field sampling plans and laboratory testing procedures (see Modules 12 and 13). The project ecologists may need to provide additional information based on FWS review comments. If a species is rare, but not legally designated as either threatened or endangered, the ERPM will need to consult with local ecologists or other experts (e.g., appropriate BTAG members) to determine the importance of the species (EPA 1989c). The draft biological assessment must be submitted to the appropriate regional office of the FWS for review. The ERPM should ensure that ecological data collection and the literature database for federally listed species is adequate to support the biological assessment. The biological assessments can be submitted to the FWS for separate review or included with the RI/FS reports.

If the FWS decides that formal consultation is needed under Section 7 of the Endangered Species Act, DOE may then be requested to revise the biological assessment and submit it as a formal report. After review of the draft biological assessment, the FWS determines whether formal consultation is necessary. 
The FWS will prepare a biological opinion for the project based on consideration of the no-action case and various remediation alternatives under consideration. The biological opinion will conclude that the project will or will not lead to further decline of the species (i.e., a jeopardy or nonjeopardy opinion). The biological opinion considers both direct project impacts on the species (i.e., death or detrimental health impacts to individual organisms) and habitat effects.

\section{References}

EPA, 1989c. Risk Assessment Guidance for Superfund - Vol. II, Environmental Evaluation Manual, report EPA/540/89/001, U.S. Environmental Protection Agency, Washington, D.C. 
MODULE 10:

WORK PLAN APPROACH

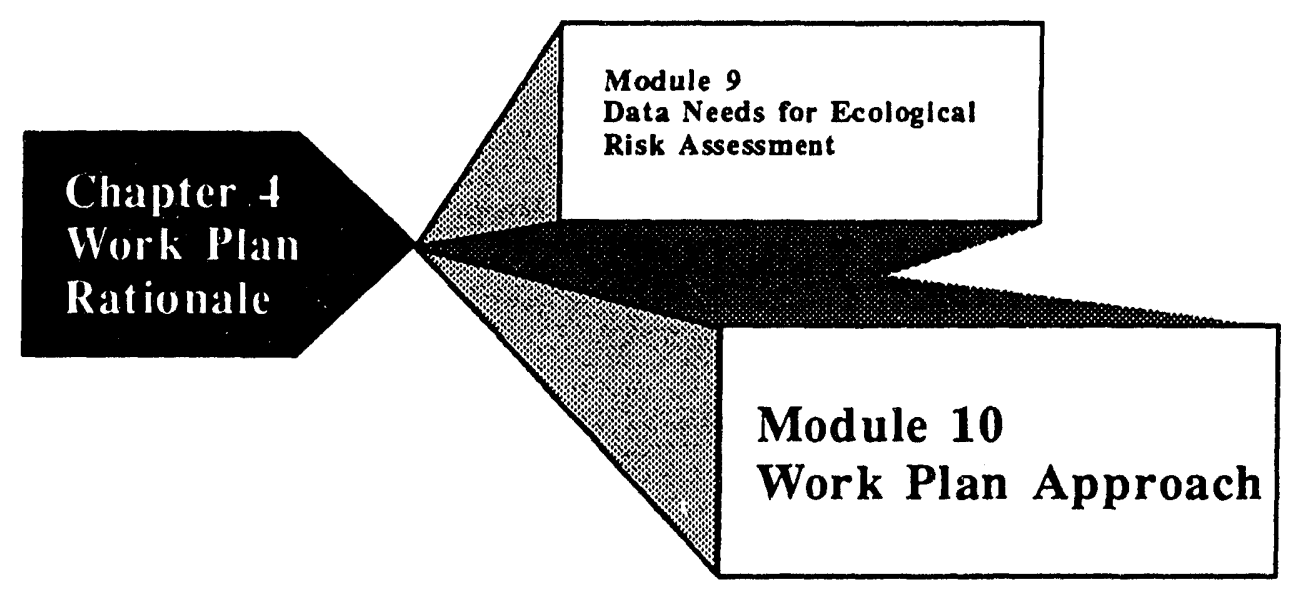




\section{Module 10: Work Plan Approach}

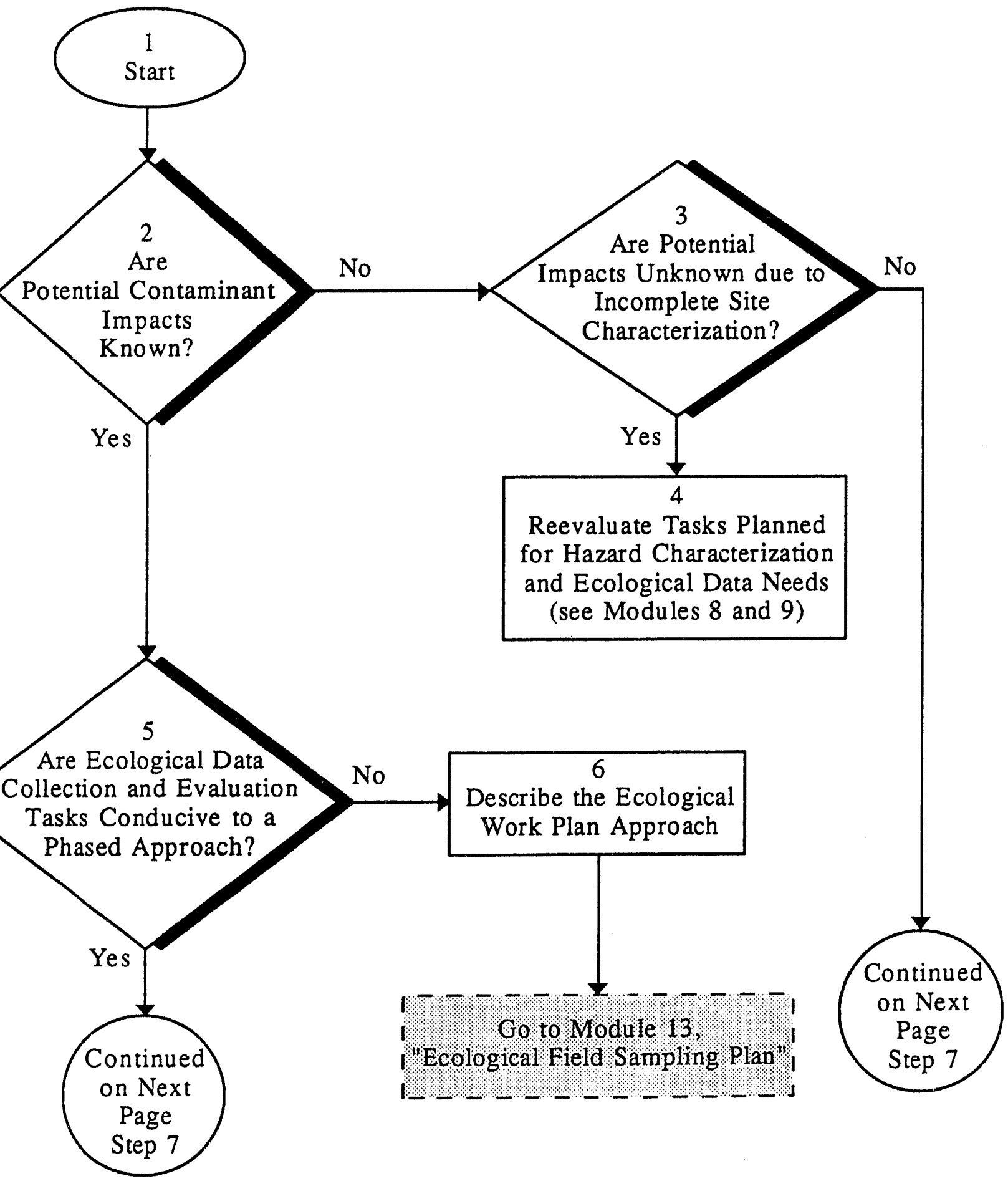




\section{MODULE 10: WORK PLAN APPROACH}

\section{Step 1 Start.}

Step 2 Potential ecological impacts can be determined from the initial evaluation of the hazardous substance, its chemical state, and spatial distribution (Chapter 3 and Module 6). In the event that potential impacts are unknown, then consideration should be given to detailed laboratory testing.

Step 3 Potential ecological impacts may not be readily determined at the time the ecological work plan is developed because of an incomplete understanding of the hazardous substances present, their state, or spatial distribution with regard to target species or sensitive biotic communities.

Step 4 A reevaluation of tasks intended to more fully characterize the chemical contaminants may be necessary at the time the ecological work plan is prepared. The ecological field data needs can then be more accurately defined (see Modules 8 and 10).

Step 5 If potential ecological impacts are well known based on previous research, the ecologist must determine whether a phased approach to the ecological risk assessment process is warranted. Unless the hazardous waste is well characterized or the site is contaminated by a single chemical element or only one compound, a phased approach to ecological risk assessment is usually necessary. The phased approach avoids the cost and time required for a comprehensive analysis of all ecosystem components when information is needed only on a few target species (see Appendix A, Section A.4). The final phase of the ecological assessment process defined in the work plan involves determining ecological risk combined with probabilistic modeling to evaluate uncertainty.

Step 6 The ecological work plan should contain a section describing the approach planned for the site in question (see Appendix A, Section A.3). Detailed descriptions of sampling tasks and data evaluation procedures should be included in the ecological field sampling plan (see Appendix B). The work plar. approach is the driver fur defining the ecological field sampling plan tasks (see Module 13). 


\section{Module 10: Work Plan Approach}

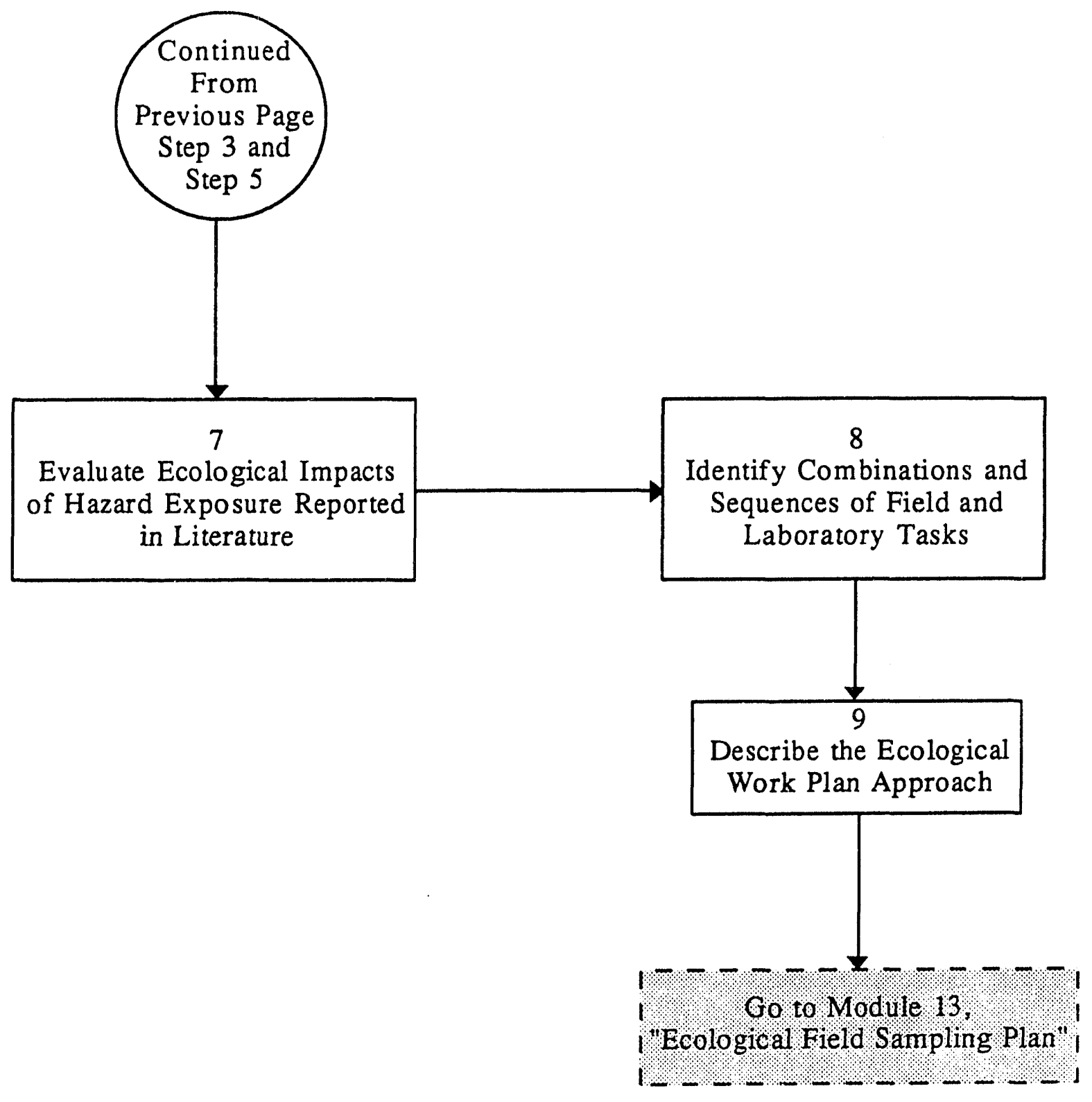


Step 7 Extrapolations can be made from scientific studies in defining the approach to be taken in the ecological risk assessment process. One important information source on known effects of environmental contaminants on fish and wildlife is a publication series prepared by the FWS. The EPA and DOE-HQ are currently developing ecotoxicology databases. The FWS has published several literature reviews on the effects of exposure of fish and wildlife to hazardous chemical elements and compounds (Eisler

Literature reviews can provide sp cific dose-response information for the species studied. Doseresponse information is useful in risk characterization or as the basis for further ecological effects studies. By comparing measured concentrations of contaminants in site media to literature values for adverse effects, investigators can decide whether there is a need to proceed with site-specific investigations (e.g., field studies or toxicity tests) (EPA 1991b). 1986, 1988a,b; Obenkirchen and

Eisler 1988). A complete listing of review publications in the contaminant hazard review series can be obtained by contacting the Section of Information Management, U.S. Fish and Wildlife Service, Patuxent Wildlife Research Center, Laurel, Maryland, 20708.

Step 8 If little is known about the ecological impacts of exposure to the chemical contaminants in question, laboratory testing of representative or surrogate species should be used to determine the types and sequence of additional field sampling and laboratory toxicity testing. Field data collection and laboratory analyses may require a sequential approach to narrow the number of species for detailed analyses (see Appendix A, Section A.3 and Figure A.2). Laboratory testing of species may be necessary to determine which contaminants at the site are causing the most serious impacts. Tissue analyses can be used to determine potential effects on a number of important animal species present on the site or site vicinity before detailed exposure studies are undertaken on a select set of target species (see Appendix A, Section A.4.1.4).

Step 9 The ecological work plan should contain a section describing the approach planned for the site in question ( see Appendix A, Section A.3). Detailed descriptions of sampling tasks and data evaluation procedures should be included in the ecological field sampling plan (see Appendix B).

\section{References}

Eisler, R., 1986. Polychlorinated Biphenyl Hazards to Fish, Wildlife, and Invertebrates: A Synoptic Review, USFWS Biological Report 85(1.7), U.S. Fish and Wildlife Service, Washington, D.C., pp. 1-72. 
Eisler, R., 1988a. Arsenic Hazards to Fish, Wildlife, and Invertebrates: A Synoptic Review, USFWS Biological Report 85(1.12), U.S. Fish and Wildlife Service, Washington, D.C., pp. 1-92.

Eisler, R., 1988b. Lead Hazards to Fish, Wildlife, and Invertebrates: A Synoptic Review, USFWS Biological Report 85(1.14), U.S. Fish and Wildlife Service, Washington, D.C., pp. 1-134.

EPA, 1991b. ECO Update, Ecological Assessment of Superfund Sites: An Overview, U.S. Environmental Protection Agency, Office of Solid Waste and Emergency Response, Intermittent Bulletin 1(2):1-8, Washington, D.C.

Obenkirchen, E.W., and R. Eisler, 1988. Chlorpyrifos Hazards to Fish, Wildlife, and Invertebrates: A Synoptic Review, USFWS Biological Report 85(1.13), U.S. Fish and Wildlife Service, Washington, D.C., pp. 1-34. 


\section{CHAPTER 5}

\section{RI/FS Tasks}

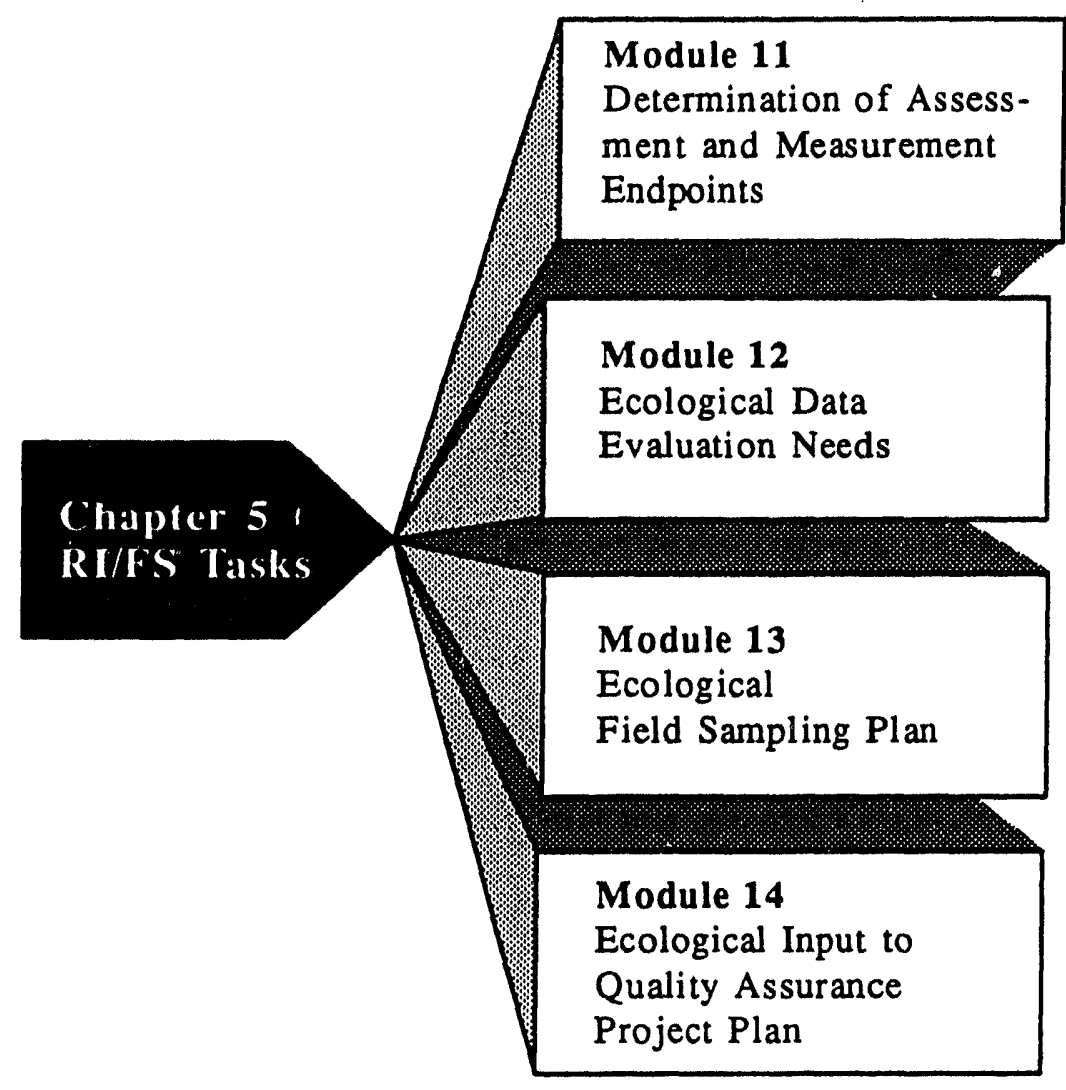

\section{CONTENTS}

Module 11: Determination of Assessment and Measurement Endpoints . . . . . . II-73

Module 12: Ecological Data Evaluation Needs . . . . . . . . . . . . . . II-79

Module 13: Ecological Field Sampling Plan $\ldots \ldots \ldots \ldots \ldots \ldots \ldots \ldots \ldots$ II-83

Module 14: Ecological Input to Quality Assurance Project Plan . . . . . . . . . . . II-87 

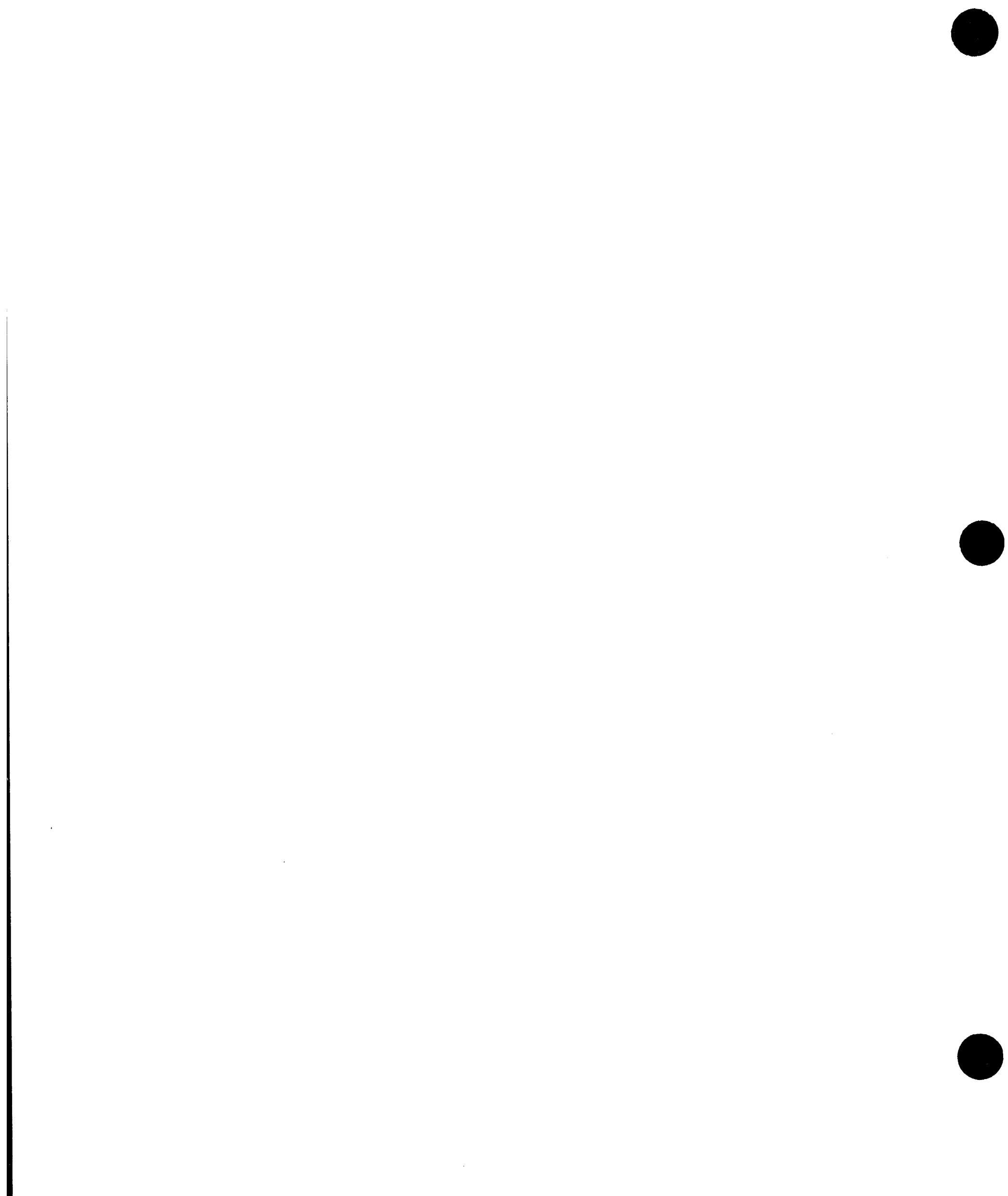

Draft: August 1993

11.70 


\section{CHAPTER 5: RI/FS TASKS}

The preliminary RI/FS work plan is prepared during the project planning phase, before remedial investigation activities are initiated. The ecological work plan should be prepared in parallel with the RI/FS plan and is a component of the overall RI/FS plan. Project ecologists must provide input to both plans. The EPA (1988a) provides guidance on the content and format of RI/FS work plans. Fourteen standard tasks are required for preparation of the RI/FS work plans.

The ecological work plan includes an ecological field sampling plan and a quality assurance project plan. In addition to task descriptions for planned field studies, the field sampling plan also includes task descriptions for laboratory toxicity testing and whole body or tissue analyses for fate and transport

\section{Ecological Data Objectives}

Defining the ecological data objectives is often an interactive or phased process. These objectives must be consistent with the 14 overall RI/FS tasks (Table 5.1 ). studies.

Preliminary ecological work plan tasks are implemented based on certain assumptions of contaminant locations, concentrations, potential exposure pathways, and receptor species. As preliminary data are obtained, sampling locations and strategies may change to more fully characterize the site and evaluate the current effects of chemical contaminants on biotic communities.

Data evaluation needs should be defined when field sampling and laboratory tests are being planned. Two EPA publications (EPA 1987, 1989b) provide guidance of field sampling methods suitable for contaminated waste/hazardous substances sites. The ecological work plan also should define data evaluation methods and the approach in establishing assessment and measurement endpoints. When possible (i.e., when the site ecosystems are well characterized at the project outset), measurement and assessment endpoints should be included in the initial ecological work plan.

The ecological field sampling plan must include tasks to (1) characterize biotic communities of the site and reference areas when applicable, (2) evaluate current ecological contamination, (3) evaluate the ecological impacts during implementation of various remediation options under consideration, and (4) allow comparisons of the postremediation ecosystems and project objectives for the intended land use. 
TABLE 5.1 Standard Tasks Required for the Preparation of an RI/FS Work Plan

\begin{tabular}{cl}
$\begin{array}{c}\text { Task } \\
\text { Number }\end{array}$ & \multicolumn{1}{c}{ Task Description } \\
\hline 1 & Project planning (project scoping) \\
2 & Community relations \\
3 & Field investigation \\
4 & Sample analysis/validation \\
5 & Data evaluation \\
6 & Assessment of risk \\
7 & Treatability study/pilot testing \\
8 & Remedial investigation reports \\
9 & Remedial alternatives \\
10 & Detailed analysis of remedial alternatives \\
11 & Feasibility study reports \\
12 & Post RI/FS support \\
13 & Enforcement support \\
14 & Miscellaneous support \\
\hline
\end{tabular}

Source: EPA (1988a)

\section{References}

EPA, 1987. A Compendium of Superfund Field Operations Methods, report EPA/540/P87/001, U.S. Environmental Protection Agency, Washington, D.C.

EPA, 1988a. Guidance for Conducting Remedial Investigations and Feasibility Studies under CERCLA, Interim Final, report EPA/540/G-89/004, OSWER Directive 9335.3-01, U.S. Environmental Protection Agency, Washington, D.C.

EPA, 1989b. Ecological Assessment of Hazardous Waste Sites: A Field and Laboratory Reference, report PB89-205967, U.S. Environmental Protection Agency, Washington, D.C. 


\section{MODULE 11:}

\section{DETERMINATION OF ASSESSMENT AND MEASUREMENT ENDPOINTS}

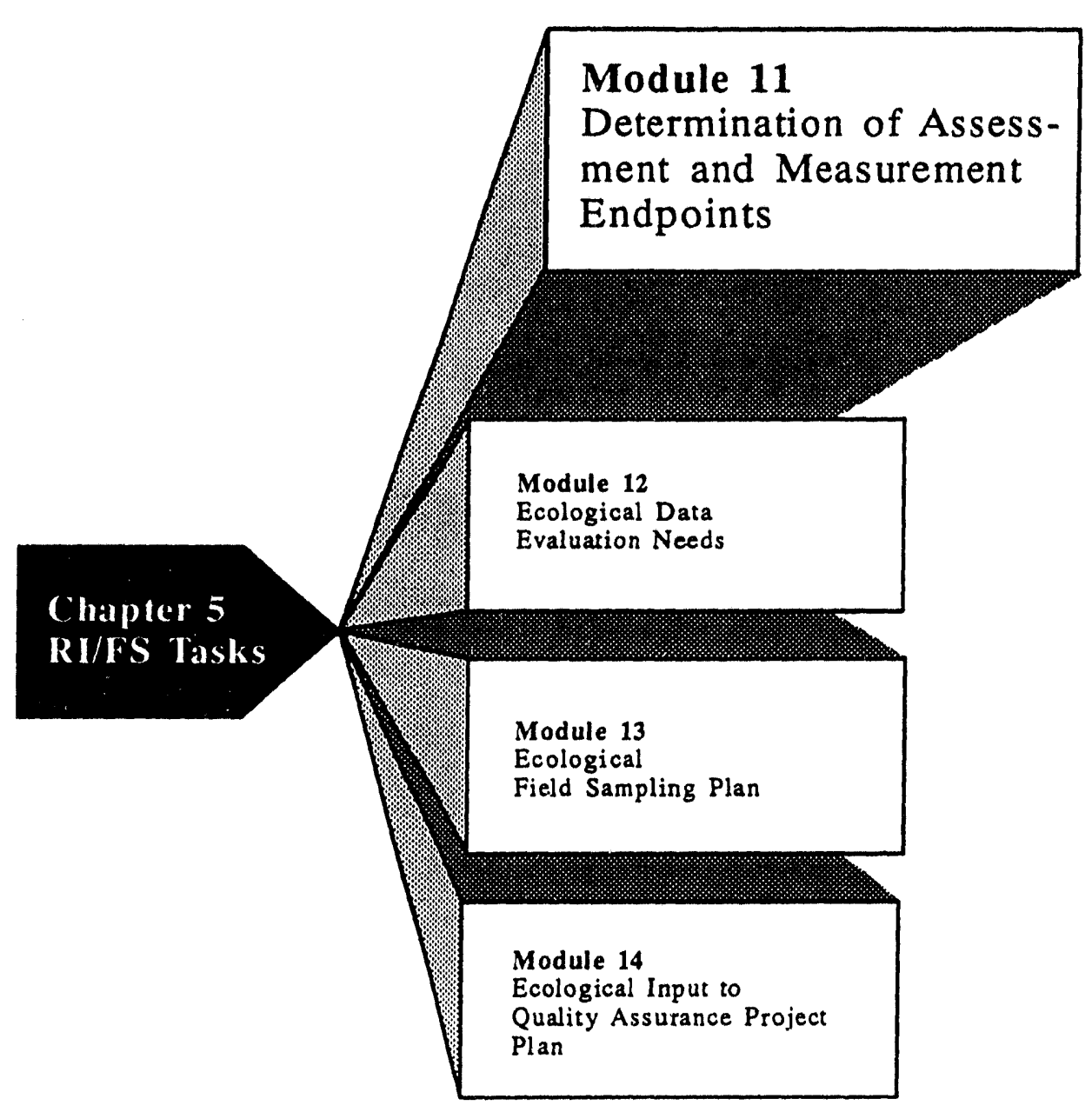




\section{Module 11: Determination of $\Lambda$ ssessment and Measurement of Endpoints}

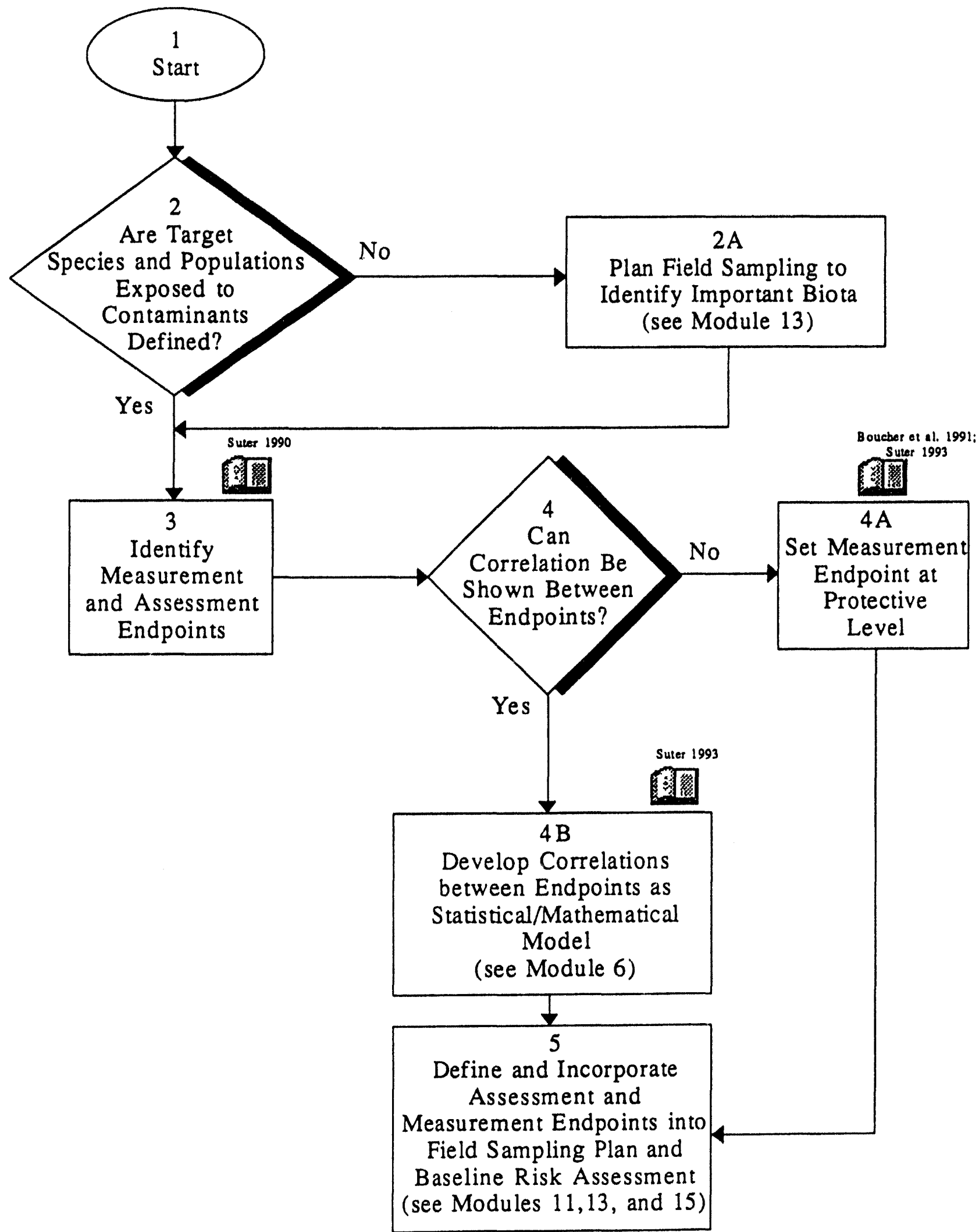




\section{MODULE 11: DETERMINATION OF ASSESSMENT AND MEASUREMENT ENDPOINTS}

Step $1 \quad$ Start.

Step 2, 2a Guidance on the assessment of impacts and measures to be monitored should be reviewed for relevance to the contaminated waste site requiring remedial action (EPA 1988a,b). Target species of concern relative to contaminant exposure should be determined. Species selected for analysis should be important with respect to community structure and ecological function.

Step 3 Selection of endpoints may be a controversial issue among project ecologists and engineers. Schedule, budget, legal protection of receptor species, importance in determining severity of ecosystem contamination, and use of ecological data in answering remediation evaluation questions need to be considered when deciding on endpoints. The DOE ERPM and project ecologist should ultimately decide on endpoints when controversies occur. The project ecologist should identify appropriate endpoints justified on the basis of technical grounds. Suter (1993, pp. 5051) identifies four steps for establishing appropriate endpoints based on technical considerations. The EPA (1989c) has provided information on the selection of assessment and measurement endpoints.

An endpoint has been defined as "a characteristic of an ecological component that may be affected by exposure to a stressor" (Suter 1990). A stressor can be considered a chemical, radiological, or physical hazard occurring at or near a contaminated site that can adversely effect resident or transient species. Stressors should be quantified and spatially defined in the site characterization phase of the RI/FS.

\section{Setting Appropriate Endpoints}

Tasks to set appropriate endpoints include (1) creating a matrix of sources of environmental contamination and ecosystem components potentially affected by the contaminants (ecosystem components are then scored on the basis of sensitivity to the hazardous substances and exposure intensity); (2) reviewing the literature to determine species sensitivity to chemical contaminants of analyses where stresses are regional in nature and impacts cannot be attributed to a point source contaminant such as a hazardous waste site; (3) identifying organisms most likely to be exposed to the contaminants based on determining ecological groups most susceptible and conducting a brief exposure assessment; and (4) determining indirect effects of the contaminant through use of diagrams or trees of causal linkages between the emissions and various environmental components. 


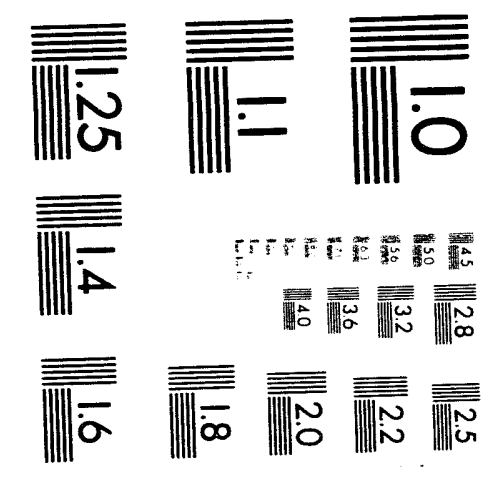



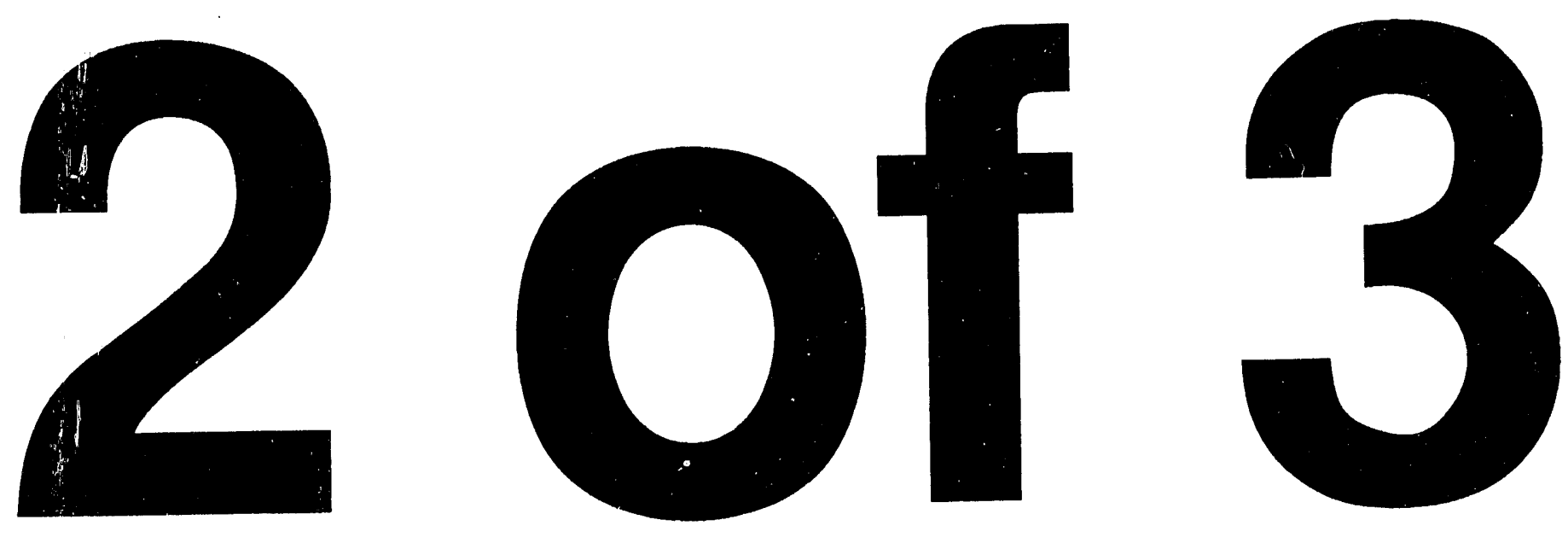

III 
Two types of endpoints should be established in project planning (i.e., assessment and measurement endpoints). The examples presented in the measurement and assessment endpoint text boxes are commonly utilized endpoints but should not be considered as all-inclusive. Some mcasurement and assessment endpoints are synonymous (e.g., population endpoint parameters). (Appendix A, Table A-2.)
Assessment endpoints are formal expressions of the actual environmental values to be protected. Examples include (1) population - extinction, abundance, yield/production, age/size class structure, and significant mortality; (2) community - market/sport value, recreational quality, and change to less useful/desired type; and (3) ecosystem - productive capability (EPA 1989b).

Step 4,4a,4b It may be possible to determine correlations between assessment and measurement endpoints witis a mathematical model. For example, the decline in abundance in fish species reproductive rates in laboratory exposures to various contaminant can be compared to reproduction rate effects in zones of varying contaminant concentration in controlled field conditions. Comparisons may then be useful in determining risk-based cleanup levels for soils, water, or sediments. As another example, the effects of various contaminant concentrations on reproductive potential and tissue concentrations in small mammals can be compared in laboratory ingestion studies to similar endpoints measured for small mammals collected at the CERCLA site and associated reference areas. These data, together with population density data, could be expressed in a mathematical model that correlates the two types of endpoints. Correlations between assessment and measurement endpoints and their use in setting cleanup levels should be evaluated in consultation with the DOE ERPM for developing overall

Measurement endpoints are quantitative expressions of an observed or measured effect of a hazard and must correspond to or predict assessment endpoints. They must be readily measured and appropriate for the exposure pathways, temporal dynamics of contaminant exposure, and scale for the site being evaluated. Examples of measurement endpoints at different hierarchical levels are (1) individual - death, growth, behavior, and tissue concentrations; (2) population -occurrence, abundance, age/size class structure, yield/production, and reproductive levels; (3) community - number of species present, species diversity, pollution indices, and community type; and (4) ecosystem biomass, productivity, ard nutrient dynamics (EPA 1989b). Good assessment endpoints should be readily measured, biologically important, and of value to society. 
remediation objectives and evaluating remediation alternatives. In cases where such correlations cannot be made, a level should be established that affords adequate protection to the most sensitive species or community types exposed to the contaminants of concern. The development of such "risk-based" levels are beyond the scope of this guidance document.

Step 5 Attention to clear definition of assessment and measurement endpoints should be a subject for discussion among experts when designing the field sampling plan. The BTAG can provide useful information on selection of species and measurement endpoints from their experience with other hazardous waste sites. The ecological work plan described in Appendix A includes information on the process of setting endpoints at a Superfund site (see Appendix A, Table A.2, Section A.3.1).

\section{References}

Boucher, P.M., et al., 1991. Ecological Exposur. Assessment of a PCB-Contaminated Wetland in Massachusetts, In: Proceedings of the 12tn National Conference Hazardous Materials Control/Superfund Conference, Washington, D.C., Dec. 3-5, Hazardous Materials Control Research Institute, Greenbelt, Md., pp. 706-709.

EPA, 1988a. Guidance for Conducting Remedial Investigations and Feasibility Studies under CERCLA, Interim Final, report EPA/540/G-89/004, OSWER Directive 9335.3-01, U.S. Environmental Protection Agency, Washington, D.C.

EPA, 1988b. Review of Ecological Risk Assessment Methods, report EPA/230/10-88/041, U.S. Environmental Protection Agency, Washington, D.C.

EPA, 1989b. Ecological Assessment of Hazardous Waste Sites: A Field and Laboratory Reference, report PB89-205967, U.S. Environmental Protection Agency, Washington, D.C.

EPA, 1989c. Risk Assessment Guidance for Superfund - Vol. II, Environmental Evaluation Manual, report EPA/540/89/001, U.S. Environmental Protection Agency, Washington, D.C.

Suter, G.W., II, 1990. Endpoints for Regional Ecological Risk Assessments, Environmental Management, 14:9-23.

Suter, G.W., II, 1993. Ecological Risk Assessment. Lewis Publishers, Chelsea, Mich., pp. 1-538. 
Draft: August 1993

II-78

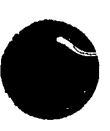




\section{MODULE 12:}

\section{ECOLOGICAL DATA EVALUATION NEEDS}

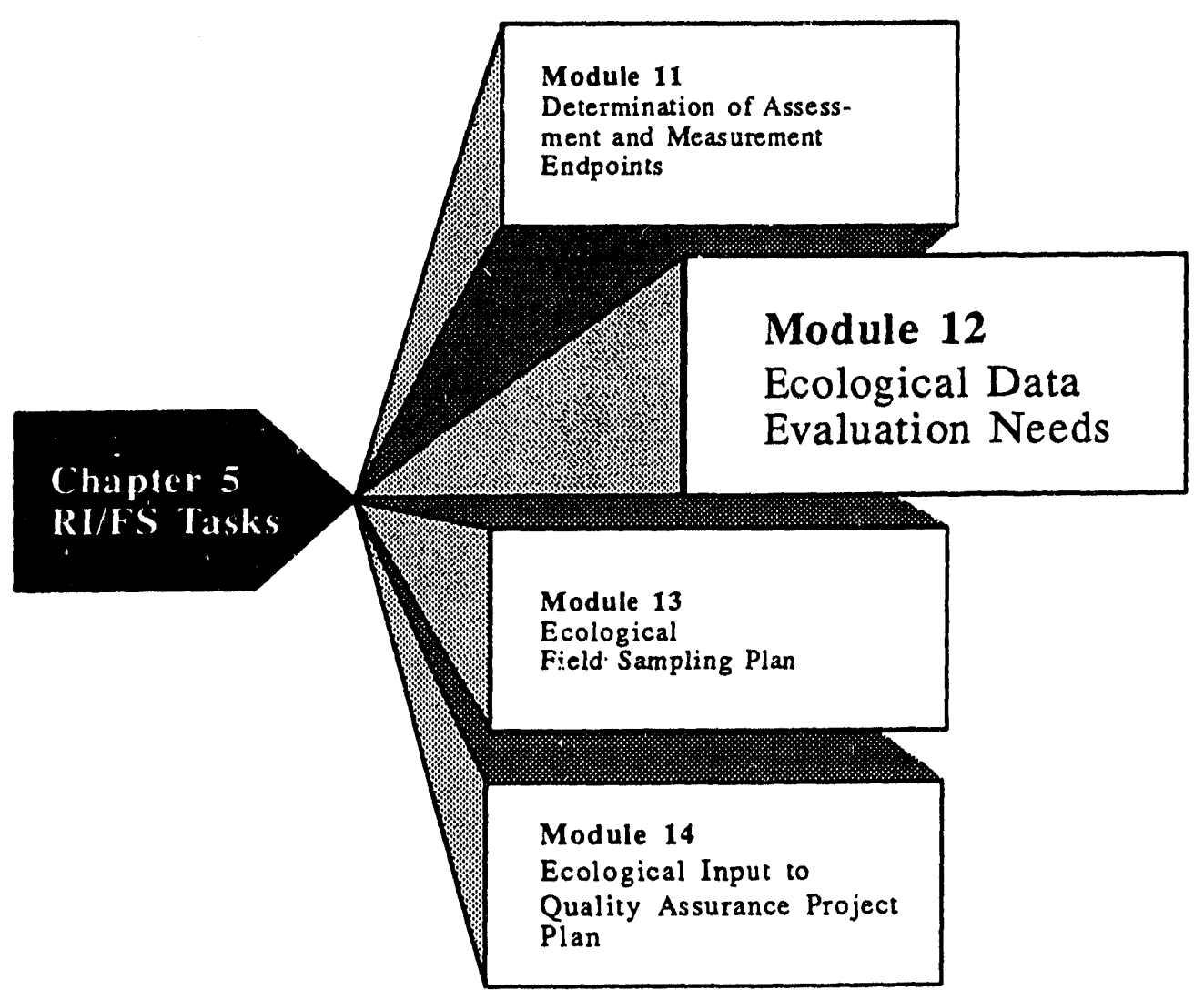




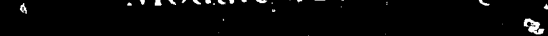

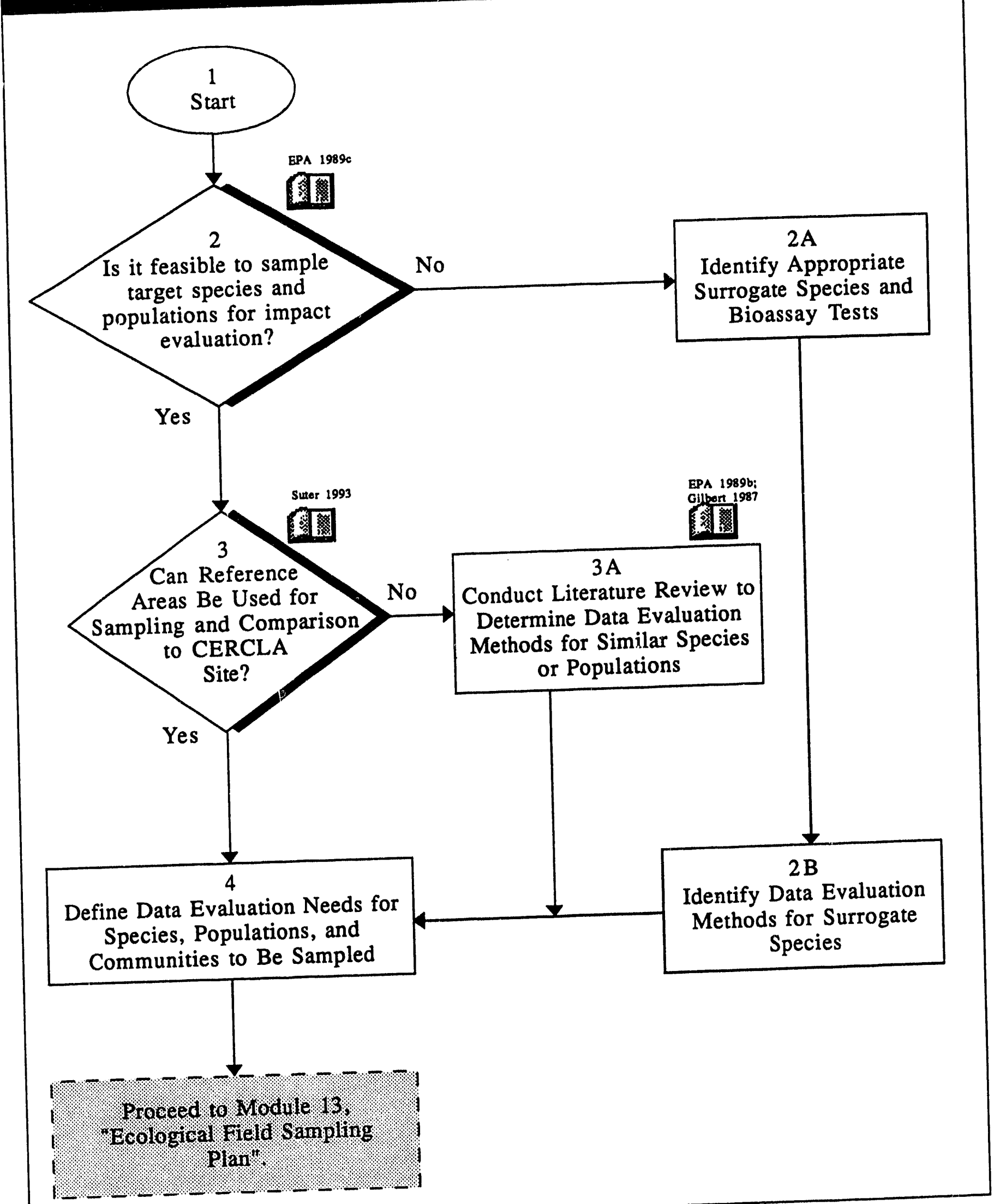


MODULE 12: ECOLOGICAL DATA EVALUATION NEEDS

Step $1 \quad$ Start.

Step 2 The site may not be conducive to field sampling for the following reasons: (1) the contaminated areas may be small and thus would not support populations large enough for statistically valid sampling, (2) the site may not be accessible because of human health and safety concerns, and (3) target species may be protected by law (e.g., bald eagles, state-listed endangered plant species). Preliminary data obtained from site visits

\section{Statistical Considerations}

It is necessary to know the types of data analyses anticipated for evaluating site ecological descriptive information and laboratory test results before the outset of data collection. Some important issues related to data evaluation are (1) the use of statistical versus nonstatistical tests, (2) the appropriateness of using hypothesis testing, (3) the applicability of using random sampling techniques, and (4) the sample size. and results of previous studies (such as at other operable units on the site or publications from other similar sites) will serve to guide the DOE ERPM and project ecologists in determining relevant ecological data to be collected. A determination should be made on the appropriateness of concentrating mainly on the sampling of target species and populations in the field or also using surrogate species in bioassay tests under laboratory conditions (EPA 1989c). Use of surrogate species is often warranted when information is needed on potential for bioaccumulation of a contaminant. Also, when a literature search indicates essentially no data on toxicity for target species being evaluated, laboratory toxicity measurements may be necessary on taxonomically similar species. Early in the planning process, ecologists should identify species or populations warranting collection of qualitative versus quantitative data. Familiarity with the species being sampled will guide ecologists in selecting appropriate statistical tools to demonstrate any effects from contaminant exposure. Natural variability in the parameters being measured must be acknowledged when attempting to show a cause-effect relationship between exposure dose and response. Specific parameters for study should be defined on the basis of assessment and measurement endpoints identified during site characterization, preliminary evaluation of field samples, and/or laboratory testing of sensitive or surrogate species. Ecological input from federal and state agencies, public interest groups, and interested individuals will help guide the planning effort by providing valuable information on the societal value and biological importance of target species or communities. 
Step 2a, 2b Laboratory and in situ bioassay tests using surrogate species may be necessary for CERCLA sites where time and cost constraints preclude conducting extensive field sampling on all possible receptor species. Generally, the scientific literature is adequate for determining the types of data analyses best suited for surrogate species subjected to hazardous wastes in the laboratory or controlled field conditions. Examples of commonly used surrogate species include earthworms, fathead minnows, lettuce Daphnia, and Hyallela. The BTAGs can provide input on the selection of appropriate surrogate species and bioassay tests (see Appendix A, Section A.4.1.4).

Step 3, 3a In some cases, reference areas can be used in the ecological assessment for comparison with the contaminated waste site (Suter 1993). When a reference area is being selected, consideration should be given to a site with similar physical properties such as soil type, slope, aspect, and moisture conditions for a terrestrial ecosystem and parameters such as flow rates, substrate type, water depth, temperature, and chemistry for an aquatic ecosystem (see Appendix A, Section A.4.1.2).

Step 4 The ecological work plan should discuss the methods of evaluating data obtained during field sampling and laboratory testing. Several references provide guidance on ecological data evaluation methods and toxicity testing methodologies appropriate for hazardous waste sites: Cochran (1977); EPA (1989b, 1991c); Gilbert (1987); Green (1979). A rationale for selecting specific statistical tests should be included in the plan (see Appendix B, Section B.7).

\section{References}

Cochran, W.G., 1977. Sampling Techniques. 3rd ed. John Wiley and Sons, Inc., New York.

Gilbert, R.O., 1987. Statistical Methods for Environmental Pollution Monitoring. Van Nostrand Reinhold, New York.

Green, R.H., 1979. Sampling Design and Statistical Methods for Environmental Biologists. John Wiley and Sons, Inc., New York.

EPA, 1989b. Ecological Assessment of Hazardous Waste Sites: A Field and Laboratory Reference, report PB89-205967, U.S. Environmental Protection Agency, Washington, D.C.

EPA, 1989c. Risk Assessment Guidance for Superfund - Vol. II, Environmental Evaluation Manual, report EPA/540/89/001, U.S. Environmental Protection Agency, Washington, D.C..

EPA, 1991c. Methods for Measuring the Acute Toxicity of Effluents and Receiving Waters to Freshwater and Marine Organisms, report EPA/600/4-90/027, U.S. Environmental Protection Agency, Environmental Monitoring Systems Laboratory, Cincinnati, Ohio.

Suter, G.W., II, 1993. Ecological Risk Assessment. Lewis Publishers, Chelsea, Mich. 


\section{MOUULE 13:}

\section{ECOLOGICAL FIELD SAMPLING PLAN}

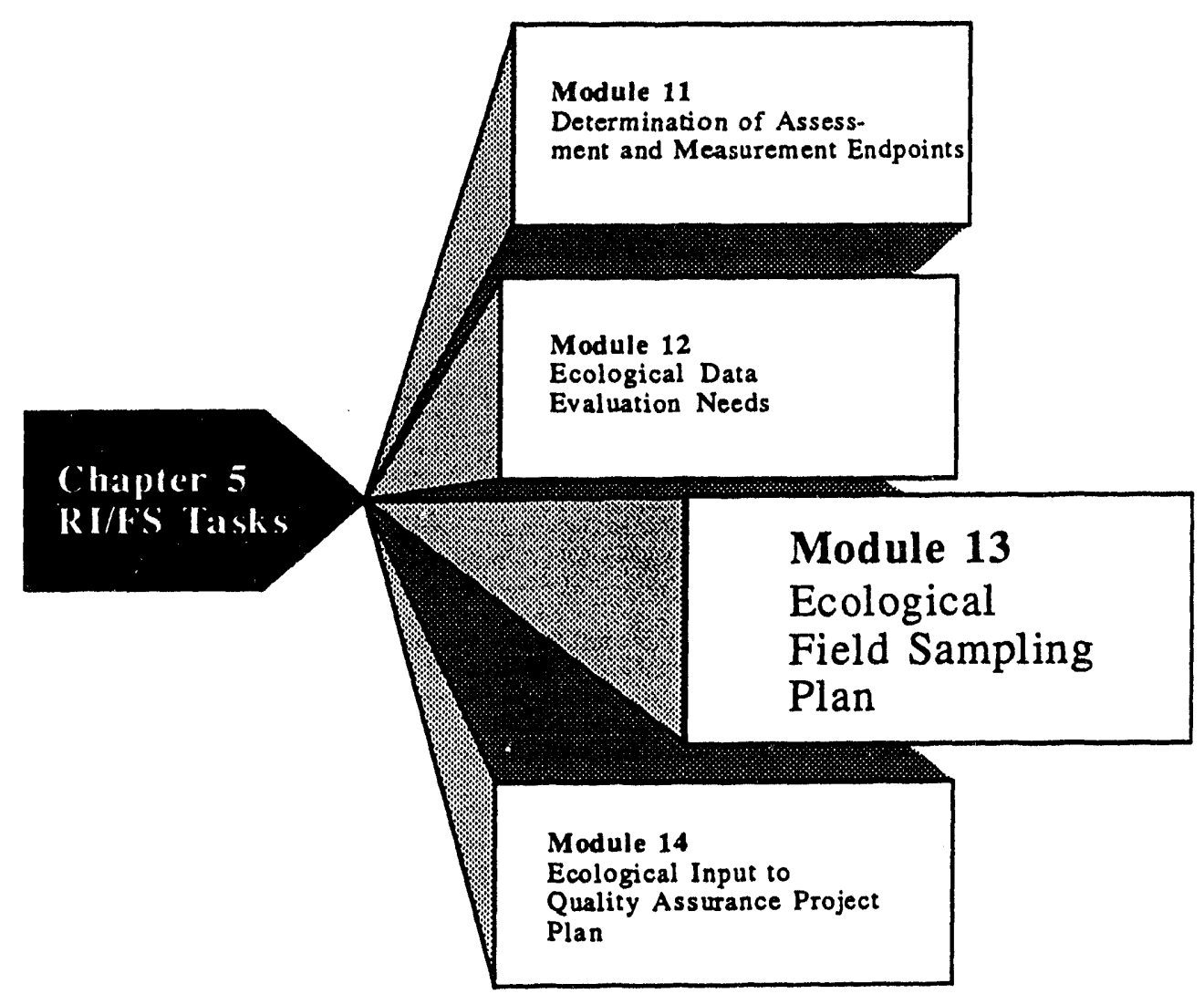




\section{Module 13: Ecological Field Sampling Plan}

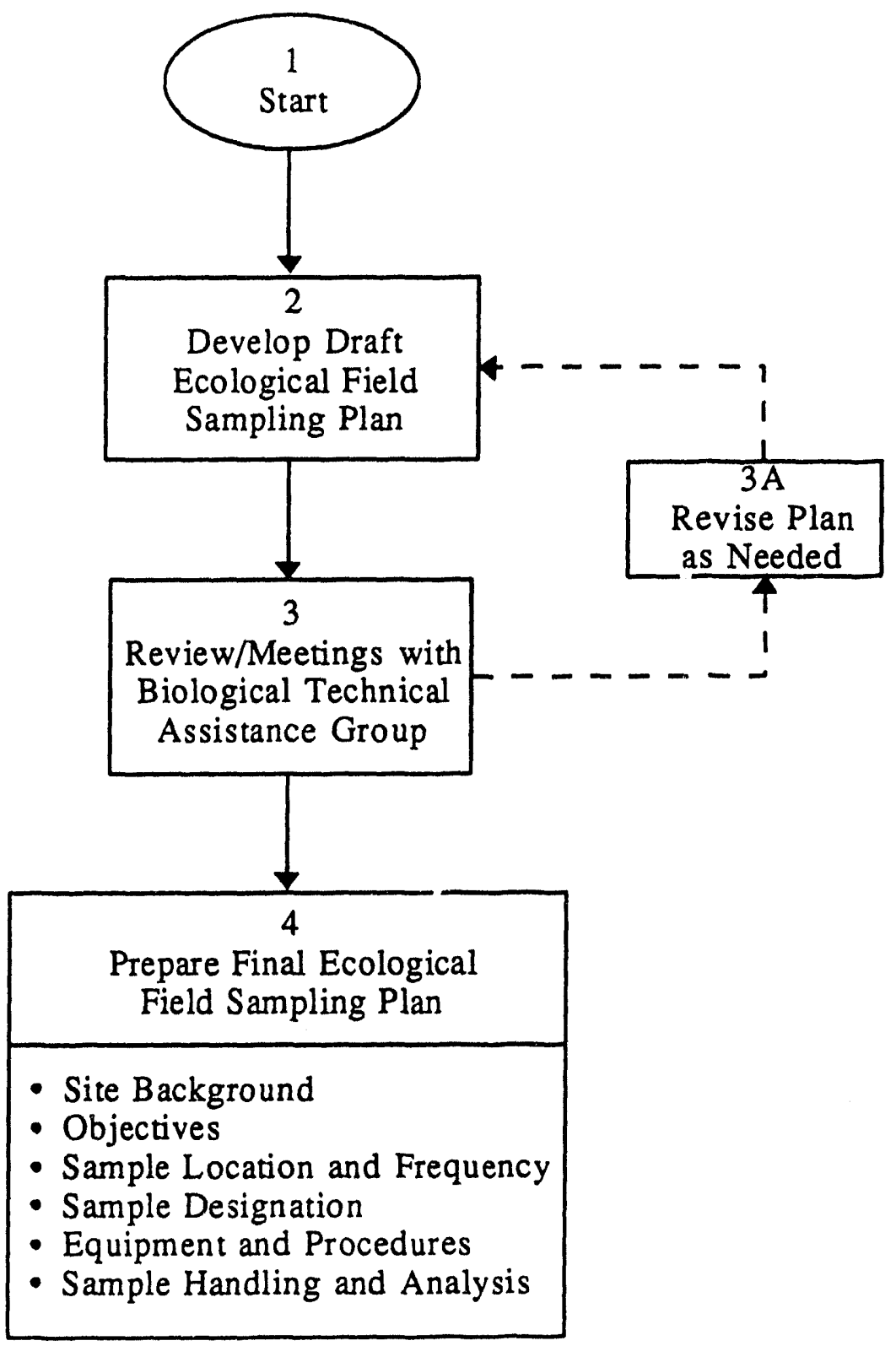




\section{MODULE 13: ECOLOGICAL FIELD SAMPLING PLAN}

Step $1 \quad$ Start.

Step 2 The planning stage of the ecological assessment process culminates in the preparation of the sampling and analysis plan (SAP), which consists of the quality assurance project plan (see Module 14) and the field sampling plan (EPA 1989c). EPA guidance on CERCLA RIs and FSs should be reviewed before the ecological component of a field sampling plan is developed. A

The field sampling plan provides guidance on all field work by detailing all of the sampling and data collection methods necessary to conduct the ecological assessment. The field sampling plan is to be prepared before field work begins, but can be amended or revised during the field investigation process. strong knowledge of the RI/FS work plan will provide ecologists with a good understanding of how ecological tasks described in the ecological work plan fit with tasks in other technical areas.

The RI/FS work plan outline is adapted to incorporate the unique conditions of the site being evaluated. The EPA allows for flexibility in the field sampling plan format and content. (An annotated table of contents for an ecological field sampling plan is provided in Appendix B.)

Step 3, 3d Meetings with the BTAG and others familiar with ecological resources of the area will expedite the review process necessary to establish the scope and content of the field sampling plan.

Step 4 The ecological field sampling plan should include the six major components depicted in Step 4 of the module diagram. Selection of equipment and sampling procedures will require input from various groups, such as state and federal agency ecologists and university researchers familiar with the ecological resources being evaluated. This interaction will ensure that state-of-the-art procedures are used for sample collection and subsequent analyses of samples. The number, size, and location of samples needed to meet sampling objectives are often controversial points between ecologists and project engineers. The DOE ERPM should contact the BTAG to obtain guidance on resolving such controversies. Ultimately, the DOE ERPM must make the final decision on sampling methodology questions. Inadequate sample size may invalidate any data collected, possibly resulting in additional sampling at a greater cost. Caution is warranted in preparing the field sampling plan to ensure that ecological data collected will also support the human health risk assessment. This approach will save both money and time in the overall RI/FS investigation of the CERCLA site. 
Ecologists should interact with the BTAG in developing the field sampling plans to ensure that adequate data are collected for subsequent ecological risk assessment determinations (EPA 1988a, 1989d).

The ecological field sampling plan should be summarized in the body of the ecological work plan and included in its entirety as an appendix to the work plan.

\section{References}

EPA, 1988a. Guidance for Conducting Remedial Investigations and Feasibility Studies under CERCLA, Interim Final, report EPA/540/G-89/004, OSWER Directive 9335.3-01, U.S. Environmental Protection Agency, Washington, D.C.

EPA, 1989c. Risk Assessment Guidance for Superfund - Vol. II, Environmental Evaluation Manual, report EPA/540/89/001, U.S. Environmental Protection Agency, Washington, D.C.

EPA, 1989d. Rapid Bioassessment Protocols for Use in Streams and Rivers: Benthic Macroinvertebrates and Fish, report EPA/444/4-89-001, J.A. Plafkin (ed.), U.S. Environmental Protection Agency, Washington, D.C. 
MODULE 14:

\section{ECOLOGICAL INPUT TO QUALITY ASSURANCE PROJECT PLAN}

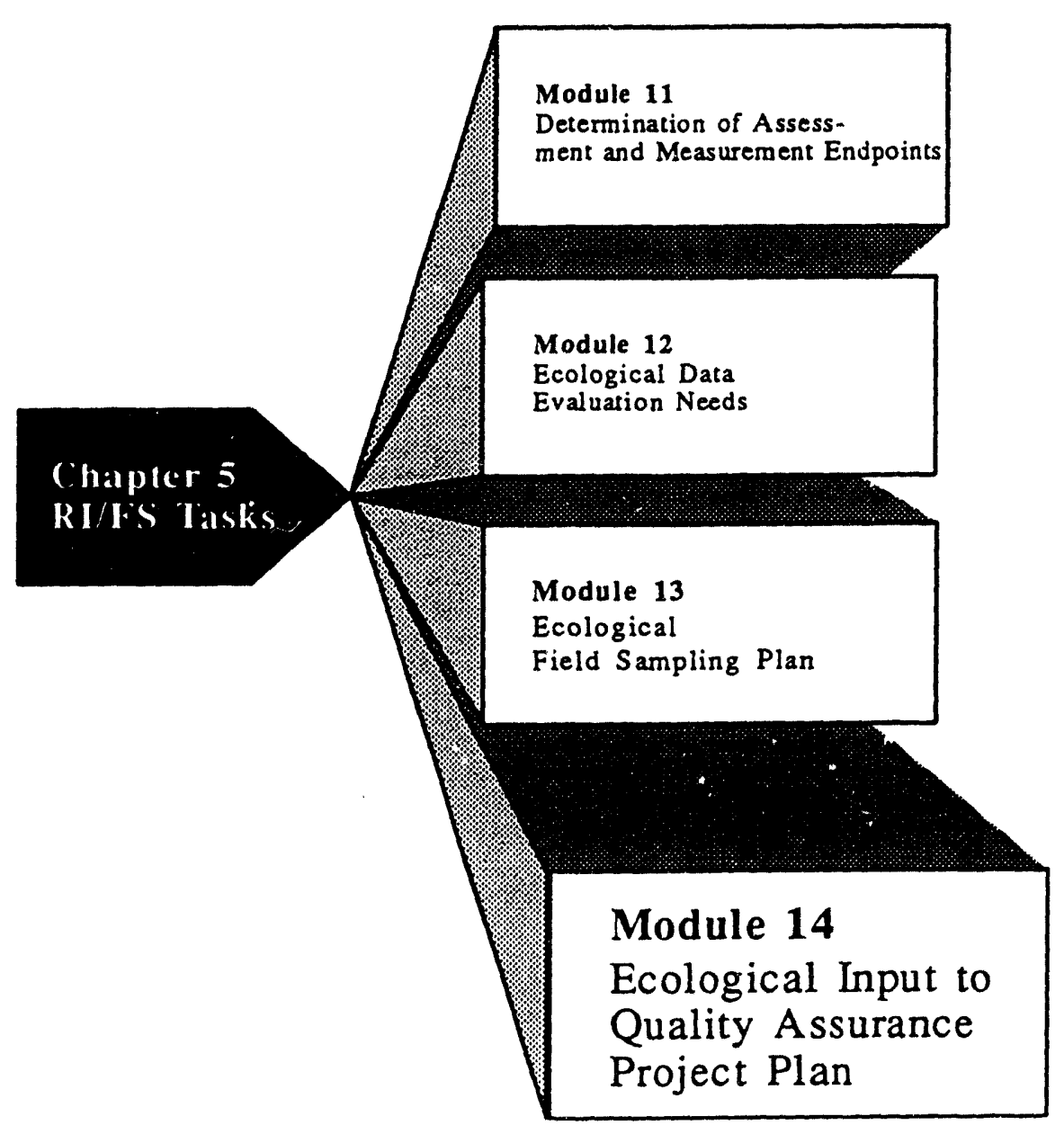




\section{Module 14: Ecological Input to Quality Assurance Project Plan}

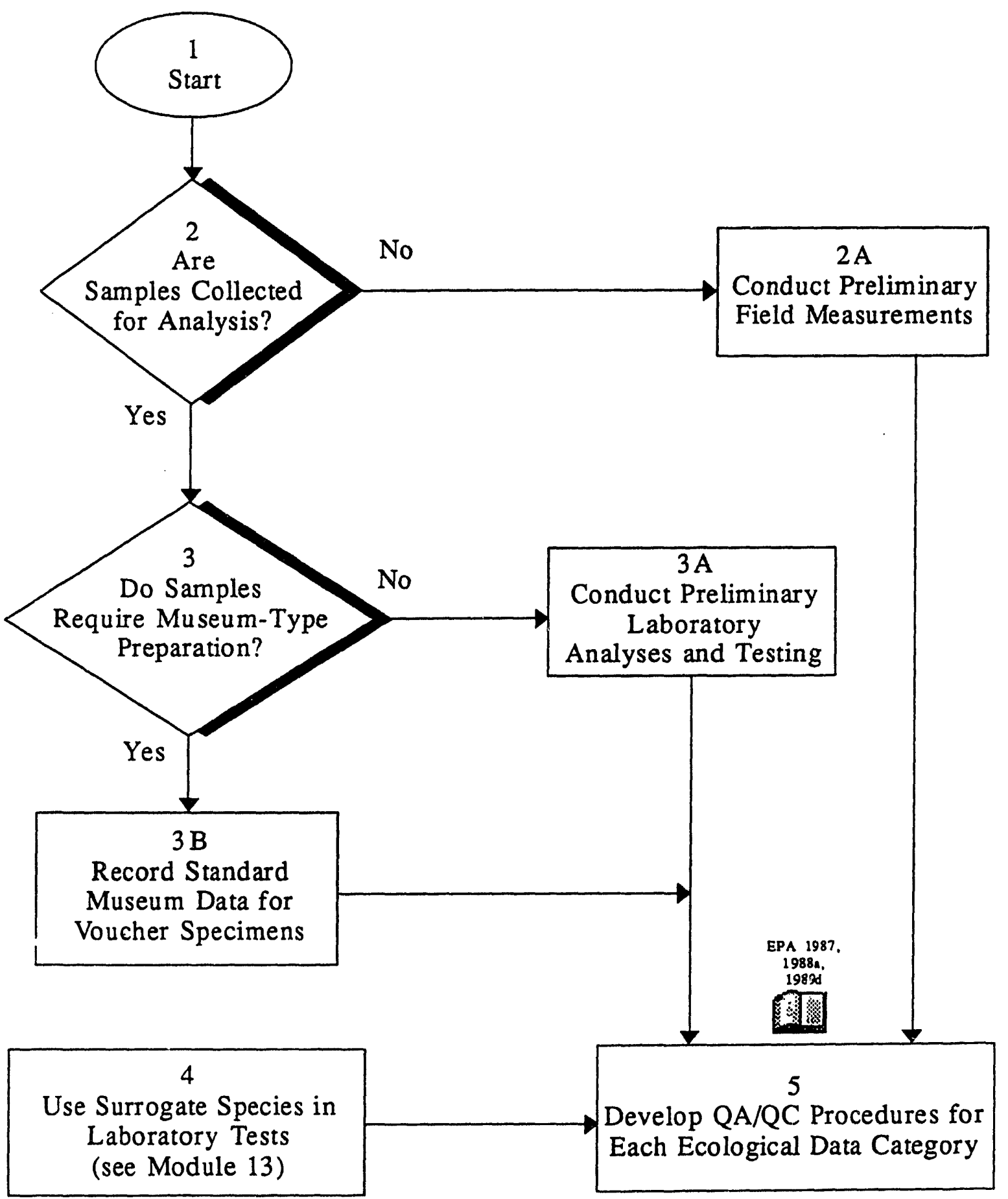




\section{MODULE 14: ECOLOGICAL INPUT TO QUALITY ASSURANCE PROJECT PLAN}

Step $1 \quad$ Start.

Step 2, 2a Guidance on contents of a quality assurance project plan (QAPP) has been prepared by the EPA (1987, 1988a). Formal quality assurance and quality control (QA/QC) procedures exist for some aspects of an ecological assessment (e.g., toxicity testing for aquatic species) but are less well defined for sampling of vegetation and terrestrial vertebrate groups. Some preliminary field

Laboratory toxicity tests must consider QAVC procedures for (1) sampling and handling hazardous wastes; (2) sources and culturing of test organisms; (3) instrument calibration and testing; (4) use of reference toxicants, adequate controls, and exposure replications; (5) record keeping; and (6) data evaluation. measurements are often helpful in defining an adequate sample for statistical analyses. The BTAG members can provide input on good QA/QC procedures based on professional experience with other CERCLA sites. Also, the BTAG coordinator from the EPA should be able to provide examples of approved QAPPs for previous projects. (A list of the EPA Regional BTAG coordinators is provided in Appendix E.)

An overview of EPA QA/QC requirements for a Superfund site is contained in Chapter 5 of the Risk Assessment Guidance for Superfund Volume II Environmental Evaluation Manual (RAGS II) (EPA 1989c). (An annotated table of contents for an ecological QAPP is provided in Appendix C.)

Step 3,3a,3b A distinction between ecological data to be collected in the field versus laboratory data from toxicity testing should be made early in developing the ecological field sampling plan. Samples may be needed to document occurrence of the species in the area. Preliminary laboratory testing will help define (1) range of variation in test result values and (2) QA/QC process relative to the number and types of tests or analyses conducted. Standard museum data records and preservation techniques best suited for the species collected should be consistently applied for the various biotic communities

\section{QAPP Elements}

Elements of a QAPP typically include: (1) introduction (purpose and scope of QAPP), (2) project bility delineation, (4) QA/QC data quality objectives, (5) sample collection and custody, (6) sample analysis, (7) system controls, (8) preventive maintenance, (9) record keeping, (10) audits, (11) corrective actions, and (12) quality control reports. description, (3) QA/QC responsi- 
sampled. Laboratory testing and chemical analyses will require QA/QC considerations of labeling, chain-of-custody record keeping, and spot checking of analyses.

Step 4 Surrogate species, rather than organisms collected from the site, may be used for laboratory testing. Appropriate procedures should be defined to ensure the quality control of data collected.

Step 5 A QAPP should include procedures to be followed in the collection of ecological, physiological, and behavioral data. Organism tests and tissue analyses in the laboratory should be clearly defined to ensure that statistically valid tests are being conducted. The following text from RAGS II provides guidance on the function and specific requirements for measurement variables:

The QAPP serves two important functions. First, it seeks to ensure that as much as possible is done at the beginning of a study to achieve the QA objectives for the data. Second, it allows for analysis of the study to determine what improvements can be made if QA objectives are not met. The plan cannot guarantee results, but it requires the analyst to justify a particular approach before proceeding.

For each major measurement variable, the QAPP must state specific data quality objectives. This is usually accomplished by preparing a table listing the variable, the sampling method, the measurement method, the experimental conditions, the target precision (measured in relative standard deviation), the target accuracy (measured in acceptable relative deviation from the true value), and completeness (measured in terms of percent coverage).

A key aspect to obtaining ecological data suitable for statistical analysis involves a clear definition of target precision and target accuracy. Gilbert (1987) provides valuable background information on these concepts, with examples from case studies of contaminated sites. Statistical tests must be clearly defined before data are collected and must be included in the QAPP for each ecological data set. This procedure will avoid the collection of extraneous information and assure that adequate samples are taken for the statistical tests. The QAPP should be prepared following EPA guidance for content and format (EPA 1988a). It is not necessary to include a site description in the QAPP if the description is contained in the ecological field sampling plan. 


\section{References}

EPA, 1987. A Compendium of Superfund Field Operations Methods, report EPA/540/P87/001, U.S. Environmental Protection Agency, Washington, D.C.

EPA, 1988a. Guidance for Conducting Remedial Investigations and Feasibility Studies under CERCLA, Interim Final, report EPA/540/G-89/004, OSWER Directive 9335.3-01, U.S. Environmental Protectiun Agency, Washington, D.C.

EPA, 1989c. Risk Assessment Guidance for Superfund - Vol. II, Environmental Evaluation Manual, report EPA/540/89/001, U.S. Environmental Protection Agency, Washington, D.C.

EPA, 1989d. Rapid Bioassessment Protocols for Use in Streams and Rivers: Benthic Macroinvertebrates and Fish, report EPA/444/4-89-001, J.A. Plafkin (ed.), U.S. Environmental Protection Agency, Washington, D.C.

Gilbert, R.O., 1987. Statistical Methods for Environmental Pollution Monitoring. Van Nostrand Reinhold, New York. 


\section{CHAPTER 6}

\section{Alternatives Evaluation}

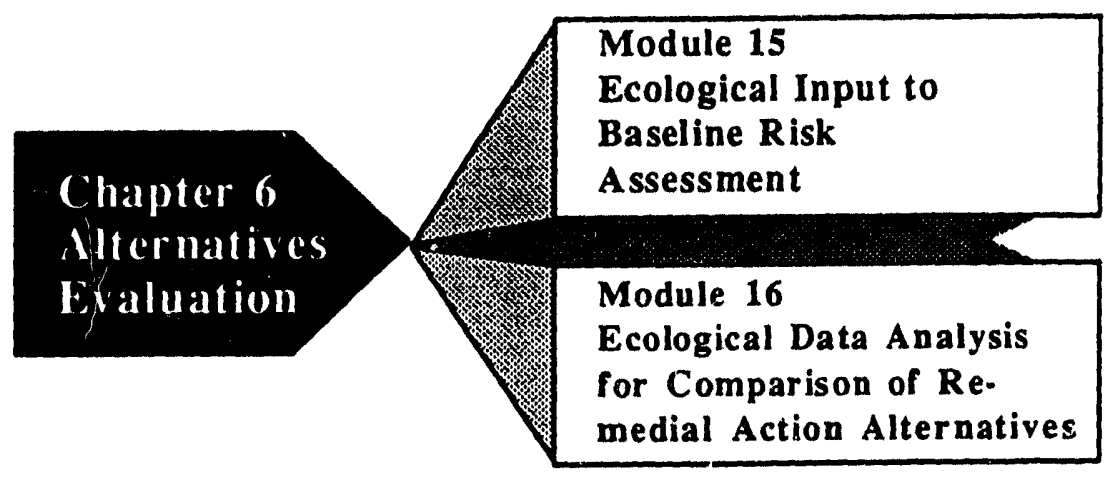

\section{CONTENTS}

Module 15: Ecological Input to Baseline Risk Assessment . . . . . . . . . . . II-97

Module 16: Ecological Data Analysis for Comparison of Remedial

Action Alternatives . . . . . . . . . . . . . . . . . . . . . . . . . II-101 


\section{CHAPTER 6: ALTERNATIVES EVALUATION}

The RI/FS work plan will include specific tasks related to collection and analysis of ecological data. The NCP [ 40 CFR 300.430 (d)] requires that ecological data be collected during the site characterization process and used in conducting a baseline risk assessment. This assessment is the no-action alternative. In some cases, however, the baseline risk assessment must be revised to reflect current interim cleanup actions. An example of a site with changing baseline conditions is the DOE Weldon Spring, Missouri, site where remediation will occur in phases, requiring a revision to the baseline assessment relative to health effects and groundwater (DOE 1992).

The ecological work plan should contain a section that addresses ecological information required to evaluate the noaction alternative either as a single assessment or a series of assessments as the baseline changes. Results of the ecological risk assessment can also be used to conduct a detailed evaluation of remediation alternatives during the FS. Nine criteria used in the FS for alternatives comparison are described in the NCP [40 CFR 300.430 (e)(9)iii] and subsequent EPA guidance (see Chapter 6 of EPA 1988a). Five of these criteria are included in Module 16 as the most relevant to ecological resources.

The first criterion - overall protection of human health and the environ-

Nine Evaluation Criteria for Analysis of Remedial Alternatives

Threshold criteria -Overall protection of human health and the environment -Compliance with ARARs

Balancing Criteria -Long-term effectiveness and permanence

-Reduction of toxicity, mobility, or volume through treatment -Short-term effectiveness -Implementability -Cost

Modifying Criteria -State acceptance -Community acceptance ment - and the criterion of compliance with ARARs are referred to as "threshold criteria" and must be met by the selected remedial alternative. Balancing criteria are considered carefully during the analysis of alternatives.

\section{References}

EPA, 1988a. Guidance for Conducting Remedial Investigations and Feasibility Studies under CERCLA, Interim Final, report EPA/540/G-89/004, OSWER Directive 9335.3-01, U.S. Environmental Protection Agency, Washington, D.C.

DOE, 1992. Baseline Assessment for the Chemical Plant Area of the Weldon Spring Site, RI/FS EIS Document: DOE/EIS-0185D; Baseline Assessment: report DOE/OR/21548-091, U.S. Department of Energy, Oak Ridge Operations Office, Oak Ridge, Tenn. 


\section{MODULE 15:}

\section{ECOLOGICAL INPUT TO BASELINE RISK ASSESSMENT}

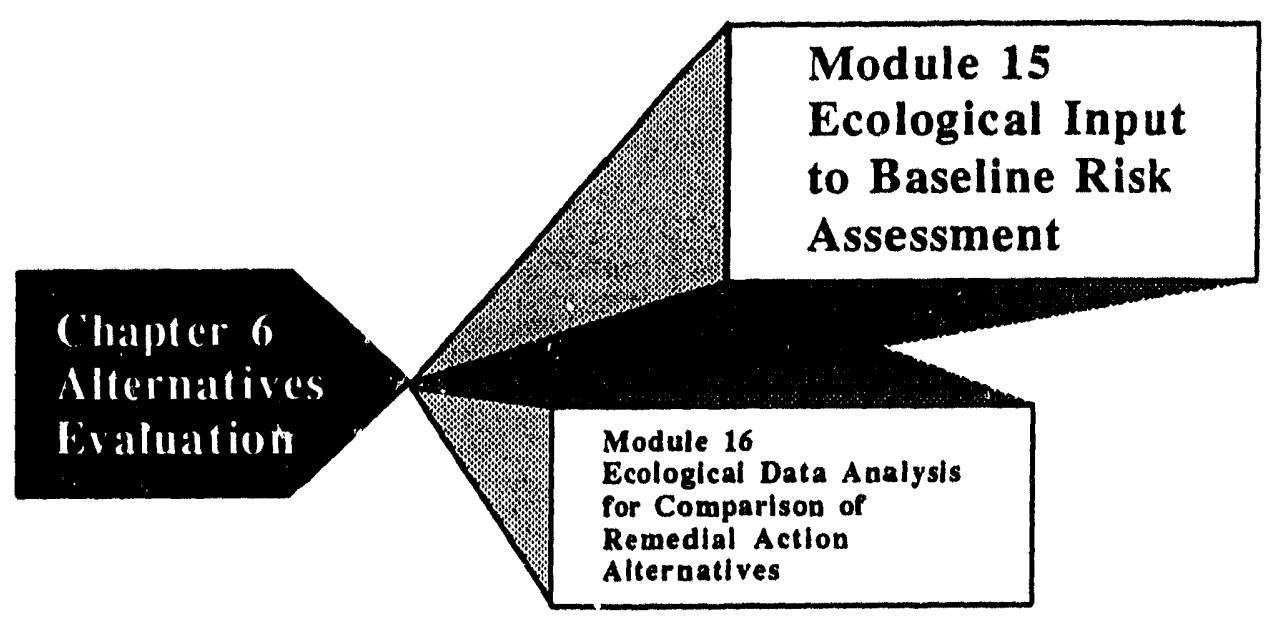




\section{Module 15: Ecological Input to Baseline Risk Assessment}

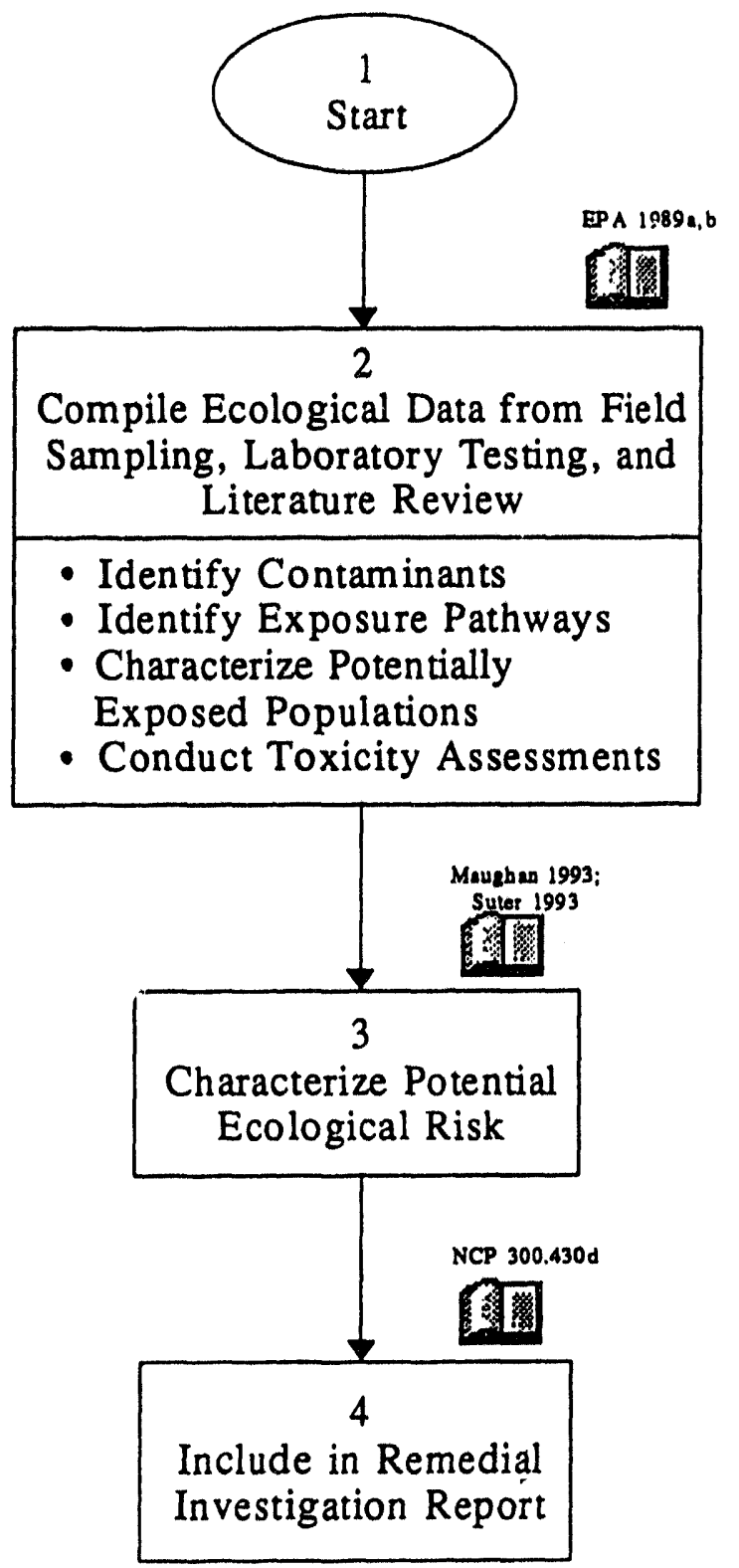




\section{MODULE 15: ECOLOGICAL INPUT TO BASELINE RISK ASSESSMENT}

\section{Step 1 Start.}

Step 2 Guidance for contractors charged with conducting baseline risk assessments should be examined before detailed planning starts for ecological aspects of the process (EPA 1988a,b). The overall ecological work plan (including the ecological field sampling plan and QAPP), when implemented, should provide all ecological data needed to conduct the baseline risk assessment. The baseline risk assessment identifies the risks associated with taking no further action (i.e., the no-action alternative in the FS report to the EPA). The baseline risk assessment should include contaminant characteristics and concentrations, exposure pathways, assessment results, receptor species and populations, and toxicity assessment results. Except for contaminant descriptions, all information should be obtained from existing ecological data or data gathered as described in the ecological field sampling plan (see Module 13) (see Appendix A, Section A.4.3).

Step 3 The conclusions regarding potential ecological risk should include supporting evidence in the form of statistically valid results of field and laboratory tests obtained through implementing procediures delineated in the overall ecological work plan. Uncertainties, variance estimates, and assumptions should be included in the analyses of baseline risk assessment data. Both Maughan (1993) and Suter (1993) cover the information needs and methods to characterize and report the

Ecological input to the baseline assessment should include a sum. mary of the following risk-related data: (1) environmental contaminant concentrations, (2) contaminant concentrations in biota, (3) toxicity test results, (4) literature values of toxicity, (5) field surveys of receptor populations, and (6) measures of community structure and ecosystem function (EPA 1989c).

Step 4 The RI report should define the ecological impacts that currently exist and that would be expected in the future if no remedial actions take place (NCP 300.430d). The goal of ecological input to the baseline risk assessment is to use toxicological and ecological information to estimate the likelihood that an undesired ecological event would occur if no remediation were undertaken.

\section{References}

EPA, 1988a. Guidance for Conducting Remedial Investigations and Feasibility Studies under CERCLA, Interim Final, report EPA/540/G-89/004, OSWER Directive 9335.3-01, U.S. Environmental Protection Agency, Washington, D.C. 
EPA, 1988b. Review of Ecological Risk Assessment Methods, report EPA/230/10-88/041, U.S. Environmental Protection Agency, Washington, D.C.

EPA, 1989a. Ecological Risk Assessment Methods: A Review and Evaluation of Past Practices in the Superfund and RCRA Programs, report EPA/230/03-89/044, U.S. Environmental Protection Agency, Washington, D.C.

EPA, 1989b. Ecological Assessment of Hazardous Waste Sites: A Field and Laboratory Reference, report PB89-205967, U.S. Environmental Protection Agency, Washington, D.C.

EPA, 1989c. Risk Assessment Guidance for Superfund - Vol. II, Environmental Evaluation Manual, report EPA/540/89/001, U.S. Environmental Protection Agency, Washington, D.C.

Maughan, J.T., 1993. Ecological Assessment of Hazardous Waste Sites. Van Nostrand Reinhold, New York.

Suter, G.W., II, 1993. Ecological Risk Assessment. Lewis Publishers, Chelsea, Mich. 
MODULE 16:

ECOLOGICAL DATA ANALYSIS FOR COMPARISON OF REMEDLAL ACTION ALTERNATIVES

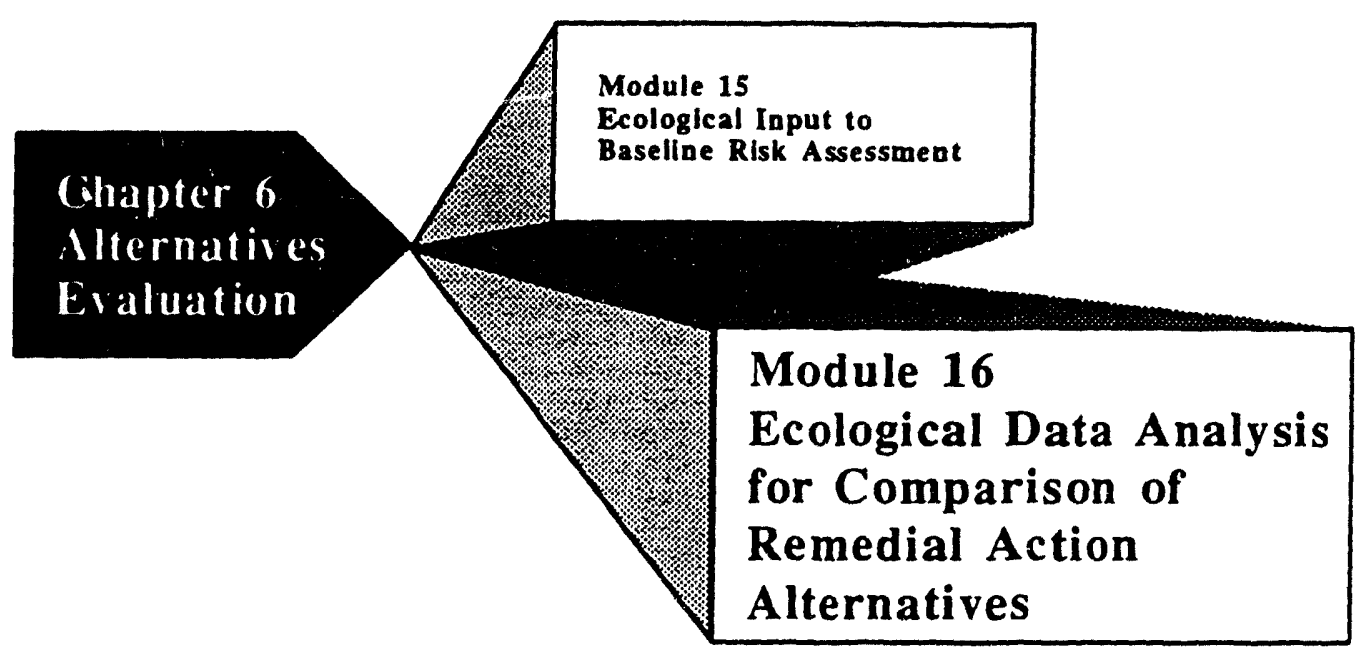




\section{Module 16: Fcological Data Analysis for Comparison of Remedial Action}

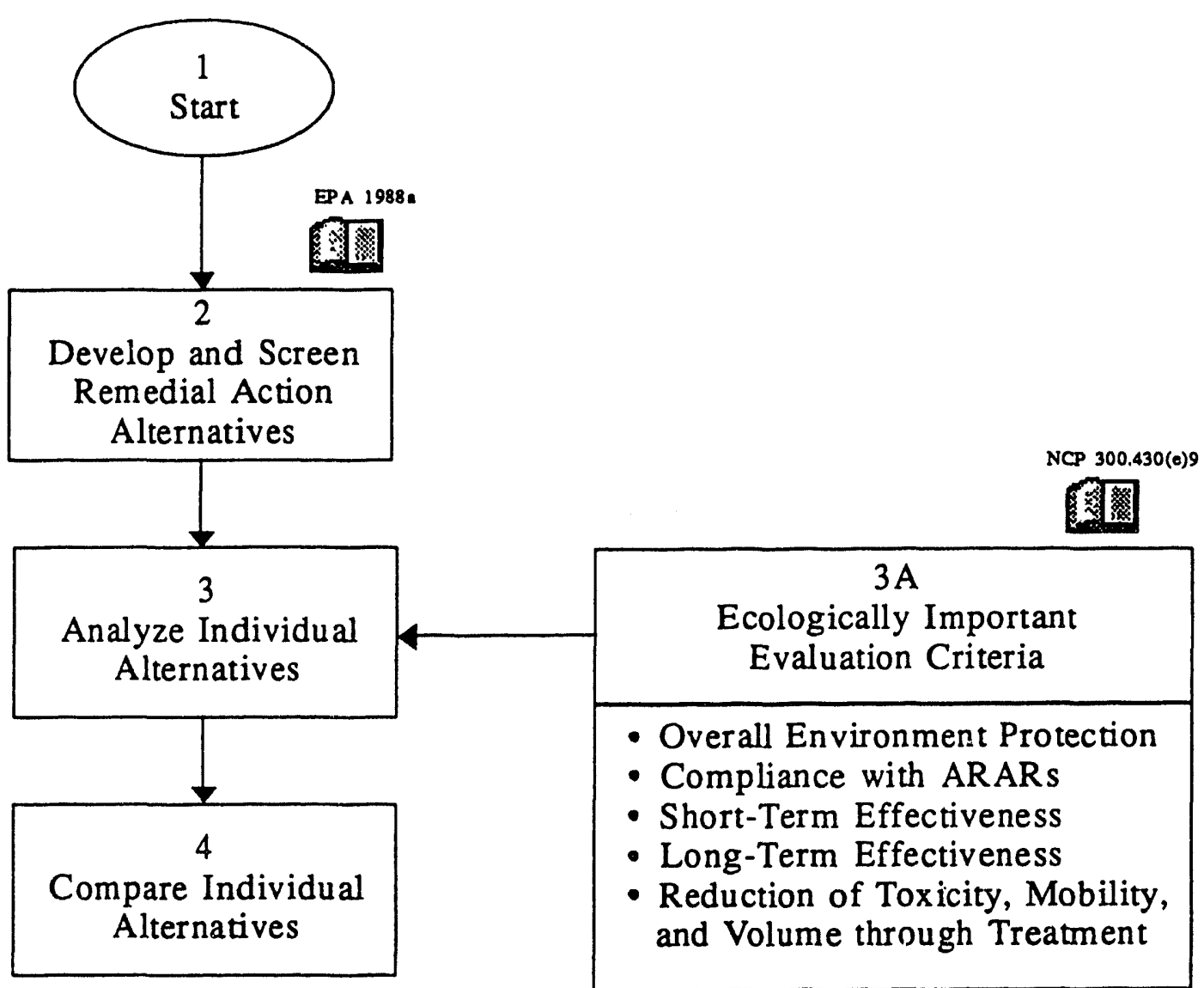




\section{MODULE 16: ECOLOGICAL DATA ANALYSIS FOR COMPARISON OF REMEDIAL ACTION ALTERNATIVES}

Step 1 Start.

Step 2 EPA guidance for conducting RIs and FSs should be reviewed by the technical staff developing remediation objectives (EPA 1988a). This module represents tasks carried out in the feasibility phase of the RI/FS process (Figure 1.1). These tasks include the identification and screening of alternatives that will remediate or control contaminated media (e.g., soil, surface water, groundwater, and sediments). Ecological input is used in screening alternatives. The regional BTAG should be consulted for detailed advice on applying ecological information to the FS process (EPA 1991a,b).

Step 3, 3a Individual alternatives identified during screening will all be subjected to the same level of detailed analyses. The nine evaluation criteria (listed in the text box of Chapter 6) should be reviewed before determining appropriate ecological input [see NCP, Part 300.430(e)9]. As identified in this step, five of the evaluation criteria are the most Ecological Assessment in the FS Process

The ecological assessment is used in the detailed analysis of remedial alternatives by identifying risks or benefits of each alternative to ecological receptors (EPA 1991a,b).

important relative to ecological resources. However, these criteria may not all apply to ecological resources at a particular site. Important considerations in evaluating each alternative against the five criteria include differences in ecological impacts associated with good engineering practices, the type of mitigation proposed, and the short-term impacts of conducting the remediation. In some cases, the ecological impacts associated with implementing the remediation could be greater than those for the no-action alternative. For example, if incineration of hazardous materials was an alternative, location of equipment and disposal of ash could impact existing habitats that are sensitive or limited in areal extent within the site vicinity. For alternatives involving excavation of the hazardous materials from wetland sites, the act of remediation could have permanent ecological impacts through loss of the wetland resource or disturbance to adjacent habitats. Also, construction of new roads for remedial action at a contaminated site may result in ecological risks of the same order of magnitude, or even have greater risk, than leaving the hazardous substances in its present location and implementing remediation measures not involving transport. Coordination in planning for new road construction is essential for minimizing ecological impacts of remediation. Project engineers and ecologists can minimize impacts to sensitive biotic communities or species through careful planning in road route selection, 
design, and construction mitigation. These issues should be considered in evaluating ecological risk of each remediation alternative.

Step 4 Summarized findings relative to the evaluation criteria will be included in tabular form for each remediation alternative. This information will be contained in the FS. The comparison of remediation alternatives may require establishing cleanup levels that afford adequate protection to the most sensitive species. For example, a very conservative approach was taken at a polychlorinated-biphenyl- (PCB-) contaminated palustrine wetland site in Massachusetts, where data from published laboratory studies were used to establish dietary levels believed to be safe for small mammals, birds, raccoon, and mink. Based on assumptions on diet composition, home range size, and bioaccumulation factors, conservative levels were set for soil/sediment cleanup of PCBs (Boucher et al. 1991). This approach was taken in the absence of sitespecific data on diet and PCB contamination levels at the site.

\section{References}

EPA, 1988a. Guidance for Conducting Remedial Investigations and Feasibility Studies under CERCLA, Interim Final, report EPA/540/G-89/004, OSWER Directive 9335.3-01, U.S. Environmental Protection Agency, Washington, D.C.

EPA, 1991a. Risk Assessment Guidance for Superfund: Volume 1-Human Health Evaluation Manual (Part B, Development of Risk-based Preliminary Remediation Goals, Office of Emergency and Remedial Response, Publication 9285.7.01B, U.S. Environmental Protection Agency, Washington, D.C.

EPA, 1991b. ECO Update, Ecological Assessment of Superfund Sites: An Overview, U.S. Environmental Protection Agency, Office of Solid Waste and Emergency Response, Intermittent Bulletin 1(2):1-8, Washington, D.C. 


\section{CHAPTER 7:}

\section{REFERENCES}

Bartell, S.M., et al., (eds.), 1992. Ecological Risk Estimation. Lewis Publishers, Chelsea, Mich.

Boucher, P.M., et al., 1991. Ecological Exposure Assessment of a PCB-Contaminated Wetland in Massachusetts, pp. 706-709, in: Proceedings of the 12th National Conference Hazardous Materials Control/Superfund Conference, Washington, D.C., Dec. 3-5, Hazardous Materials Control Research Institute, Greenbelt, Md.

Cochran, W.G., 1977. Sampling Techniques, 3rd ed. John Wiley and Sons, Inc., New York.

DOE, 1991. Natural Resource Trusteeship and Ecological Evaluation for Environmental Restoration at Department of Energy Facilities, report DOE/EH-0192, U.S. Department of Energy, Washington, D.C.

DOE, 1992. Baseline Assessment for the Chemical Plant Area of the Weldon Spring Site, RIFS EIS Document: DOE/EIS-0185D; Baseline Assessment: DOE/OR/21548-091, U.S. Department of Energy, Oak Ridge Operations Office, Oak Ridge, Tenn.

DOE, 1993a. Remedial Investigation/Feasibility Study (RI/FS) Process and Techniques Guidance, Interim Draft Final, U.S. Department of Energy, Office of Environmental Guidance, Washington, D.C., May.

DOE, 1993b. Policy Framework and Implementation Plan for Using Ecological Risk Assessment at DOE Facilities, DOE/RL/01830-H16, U.S. Department of Energy, Washington, D.C.

Eisler, R., 1986. Polychlorinated Biphenyl Hazards to Fish, Wildlife, and Invertebrates: A Synoptic Review, USFWS Biological Report 85(1.7), U.S. Fish and Wildlife Service, Washington, D.C.

Eisler, R., 1988a. Arsenic Hazards to Fish, Wildlife, and Invertebrates: A Synoptic Review, USFWS Biological Report 85(1.12), U.S. Fish and Wildlife Service, Washington, D.C.

Eisler, R., 1988b. Lead Hazards to Fish, Wildlife, and Invertebrates: A Synoptic Review, USFWS Biological Report 85(1.14), U.S. Fish and Wildlife Service, Washington, D.C.

EPA, 1987. A Compendium of Superfund Field Operations Methods, report EPA/540/P87/001, U.S. Environmental Protection Agency, Washington, D.C.

EPA, 1988a. Guidance for Conducting Remedial Investigations and Feasibility Studies under CERCLA, Interim Final, report EPA/540/G-89/004, OSWER Directive 9335.3-01, U.S. Environmental Protection Agency, Washington, D.C. 
EPA, 1988b. Review of Ecological Risk Assessment Methods, report EPA/230/10-88/041, U.S. Environmental Protection Agency, Washington, D.C.

EPA, 1989a. Ecological Risk Assessment Methods: A Review and Evaluation of Past Practices in the Superfund and RCRA Programs, report EPA/230/03-89/044, U.S. Environmental Protection Agency, Washington, D.C.

EPA, 1989b. Ecological Assessment of Hazardous Waste Sites: A Field and Laboratory Reference, report PB89-205967, U.S. Environmental Protection Agency, Washington, D.C.

EPA, 1989c. Risk Assessment Guidance for Superfund - Vol. II, Environmental Evaluation Manual, report EPA/540/89/001, U.S. Environmental Protection Agency, Washington, D.C.

EPA, 1989d. Rapid Bioassessment Protocols for Use in Streams and Rivers: Benthic Macroinvertebrates and Fish, report EPA/444/4-89-001, J.A. Plafkin (ed.), U.S. Environmental Protection Agency, Washington, D.C.

EPA, 1991a. Risk Assessment Guidance for Superfund: Volume 1-Human Health Evaluation Manual (Part B, Development of Risk-based Preliminary Remediation Goals, Publication 9285.7.01B, Office of Emergency and Remedial Response, U.S. Environmental Protection Agency, Washington, D.C.

EPA, 1991b. ECO Update, Ecological Assessment of Superfund Sites: An Overview, U.S. Environmental Protection Agency, Office of Solid Waste and Emergency Response, Intermittent Bulletin 1(2):1-8, Washington, D.C.

EPA, 1991c. Methods for Measuring the Acute Toxicity of Effluents and Receiving Waters to Freshwater and Marine Organisms, U. S. Environmental Protection Agency, Environmental Monitoring Systems Laboratory, Cincinnati, report EPA/600/4-90/027, U.S. Environmental Protection Agency, Washington, D.C.

EPA, 1992a. Framework for Ecological Risk Assessment, report EPA/630/R-92/001, U.S. Environmental Protection Agency, Washington, D.C.

EPA, 1992b. ECO Update, Developing a Work Scope for Ecological Assessments, U.S. Environmental Protection Agency, Office of Solid Waste and Emergency Response, Intermittent Bulletin 1(4):1-15., Washington, D.C.

FWS, 1979. Selected List of Federal Laws and Treaties Relating to Sport Fish and Wildlife, Fish and Wildlife Service, Washington, D.C.

Gilbert, R.O., 1987. Statistical Methods for Environmental Pollution Monitoring. Van Nostrand Reinhold, New York.

Green, R.H., 1979. Sampling Design and Statistical Methods for Environmental Biologists. John Wiley and Sons, Inc., New York. 
Maughan, J.T., 1993. Ecological Assessment of Hazardous Waste Sites. Van Nostrand Reinhold, New York.

Newman, M.C., and A.W. McIntosh (eds.), 1991. Metal Ecotoxicology, Concepts and Applications. Lewis Publishers, Inc., Chelsea, Mich.

Obenkirchen, E.W., and R. Eisler, 1988. Chlorpyrifos Hazards to Fish, Wildlife, and Invertebrates: A Synoptic Review, USFWS Biological Report 85(1.13), Fish and Wildlife Service, Washington, D.C.

ORNL, 1993. Environmental Guidance Program Reference Book, Comprehensive Environmental Response, Compensation, and Liability Act, report ORNL/M-2261, Oak Ridge National Laboratory, Oak Ridge, Tenn.

Peterle, T.J., 1991. Wildlife Toxicology. Van Nostrand Reinhold, New York.

Suter, G.W., II, 1990. Endpoints for Regional Ecological Risk Assessments, Environmental Management 14:9-23.

Suter, G.W., II, 1993. Ecological Risk Assessment. Lewis Publishers, Chelsea, Mich. 


\section{CONTENTS}

APPENDIX A: Example of an Ecological Assessment Work Plan . . . . . . . . . . III-7

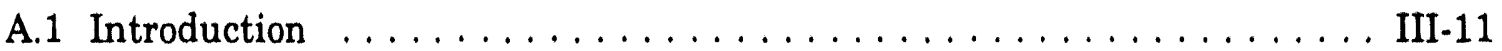

A.1.1 Background and Site History $\ldots \ldots \ldots \ldots \ldots \ldots \ldots$ III-11

A.1.2 Physical Setting . . . . . . . . . . . . . . . . III-13

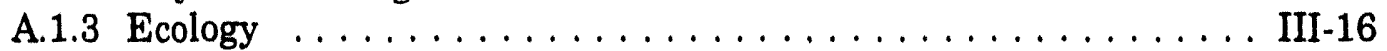

A.2 Work Plan Rationale . . . . . . . . . . . . . . . . . . . . . . . III-19

A.3 Study Approach and Data Requirements . . . . . . . . . . . . III-21

A.3.1 Ecological Receptors . . . . . . . . . . . . . . . . . . III-24

A.3.2 Systems Model and Pathway Analysis . . . . . . . . . . III-25

A.3.3 Published Standard Methods and Protocols . . . . . . . . . . . . III-25

A.3.4 Literature Search of Toxic Effects of Known

Contaminants at the Site . . . . . . . . . . . . . . . . . . . III-27

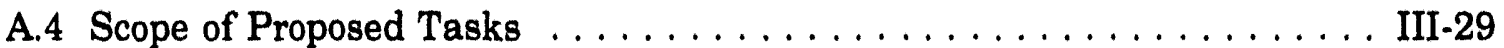

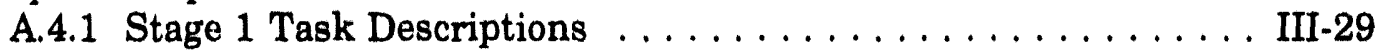

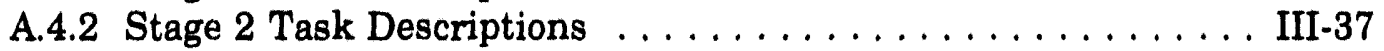

A.4.3 Stage 3 Determination of Ecological Risk . . . . . . . . . . . III-38

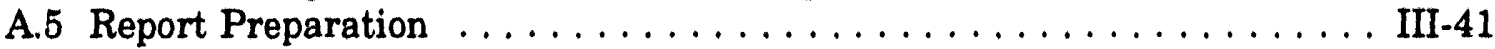

A.6 Sampling Protocol $\ldots \ldots \ldots \ldots \ldots \ldots \ldots \ldots \ldots \ldots \ldots \ldots$ III -43

A.6.1 Sampling Strategy $\ldots \ldots \ldots \ldots \ldots \ldots \ldots \ldots \ldots \ldots$ III -43

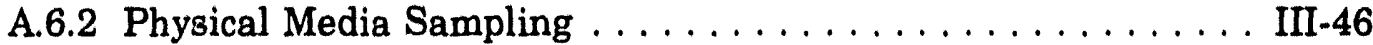

A.6.3 Reference Area . . . . . . . . . . . . . . . . . . . . . . III-46

A.7 Quality Assurance, Quality Control, and Chain-of-Custody

Procedures . . . . . . . . . . . . . . . . . . . . . . . . III-47

A.7.1 Quality Assurance Measures . . . . . . . . . . . . III-47

A.7.2 Data Management . . . . . . . . . . . . . . . . . III-47

A.8 Technical Support and Facilities $\ldots \ldots \ldots \ldots \ldots \ldots \ldots \ldots \ldots$ III-49

A.9 References $\ldots \ldots \ldots \ldots \ldots \ldots \ldots \ldots \ldots \ldots \ldots \ldots \ldots \ldots \ldots$ III-51

APPENDIX B: Ecological Field Sampling Plan Annotated Outline . . . . . . . . III-55

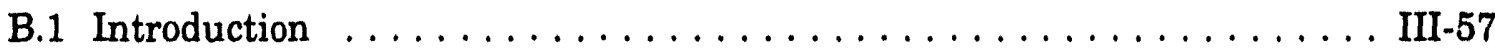

B.1.1 Background ....................... III-57

B.1.2 Objective and Scope of the Field Sampling Plan . . . . . . . . III-57

B.1.3 Report Organization . . . . . . . . . . . . . . . . . III-57

B.2 Site Setting and Background $\ldots \ldots \ldots \ldots \ldots \ldots \ldots \ldots \ldots \ldots \ldots$ III-57

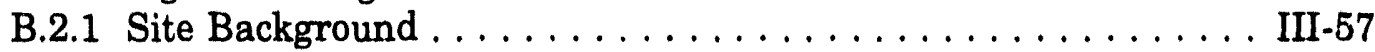

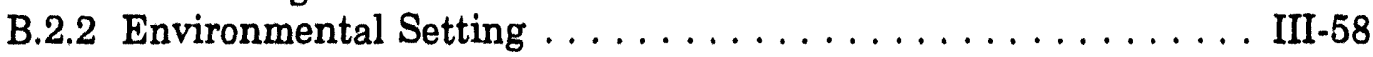

B.2.3 Previous Investigations $\ldots \ldots \ldots \ldots \ldots \ldots \ldots \ldots \ldots$ III-58

B.2.4 Concurrent Investigations $\ldots \ldots \ldots \ldots \ldots \ldots \ldots \ldots$ III-59

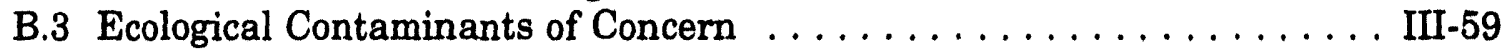

B.4 Contaminant Transport and Fate Analysis $\ldots \ldots \ldots \ldots \ldots \ldots$. . . . . . . . . .

B.4.1 Data Gaps . . . . . . . . . . . . . . . . . . . . III-59

B.4.2 Conceptual Site Model . . . . . . . . . . . . . . . III-59

B.4.3 Transport Analysis . . . . . . . . . . . . . . . . . III-59 


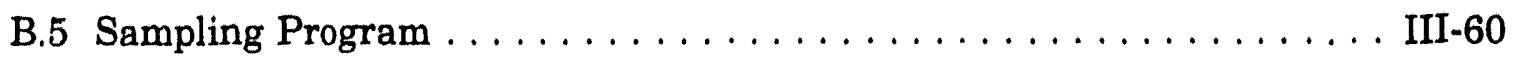

B.5.1 Site Selection ....................... III 60

B.5.2 Sample Collection and Survey Methods . . . . . . . . . . III-61

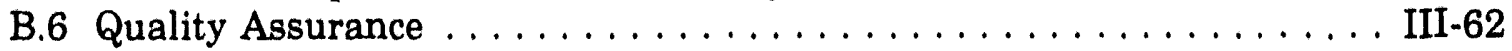

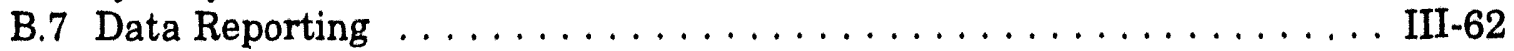

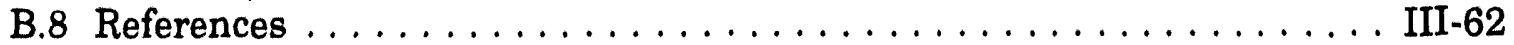

APPENDIX C: Ecological Quality Assurance Project Plan $\ldots \ldots \ldots \ldots \ldots \ldots$ III-63

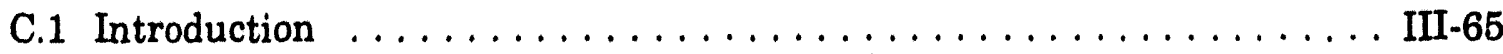

C.1.1 Purpose of the Quality Assurance Project Plan ........... III-65

C.1.2 Scope of the Quality Assurance Project Plan . . . . . . . . . . III-65

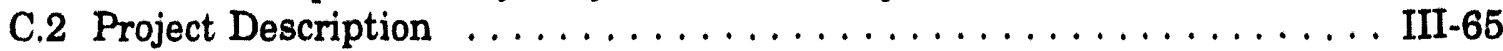

C.2.1 Project Scope ............................ III-65

C.2.2 Project Objective $\ldots \ldots \ldots \ldots \ldots \ldots \ldots \ldots \ldots \ldots \ldots$ III-66

C.2.3 Site Background . . . . . . . . . . . . . . . . . . . . . III-66

C.2.4 Field Operations . ....................... III-66

C.3 Project and QA/QC Organization and Responsibility ........... III-66

C.3.1 Responsibilities .......................... III-66

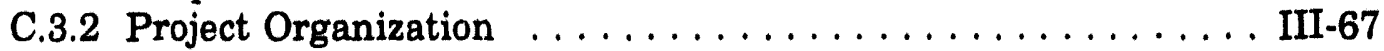

C.4 Quality Assurance and Data Quality Objectives $\ldots \ldots \ldots \ldots \ldots \ldots$ III-67

C.4.1 Quality Assurance $\ldots \ldots \ldots \ldots \ldots \ldots \ldots \ldots \ldots \ldots \ldots$ III-67

C.4.2 Data Quality Objectives ..................... III-68

C.4.3 Controlling and Assessing the Quality of Data . . . . . . . . III-69

C.5 Sampling ................................ III-69

C.5.1 Sample Labeling $\ldots \ldots \ldots \ldots \ldots \ldots \ldots \ldots \ldots \ldots$ III-69

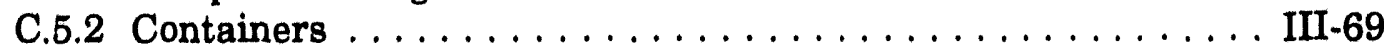

C.5.3 Sample Preservation $\ldots \ldots \ldots \ldots \ldots \ldots \ldots \ldots \ldots \ldots$ III-69

C.5.4 Sample Collection . . . . . . . . . . . . . . . . . . . III-70

C.5.5 Sample Custody . ....................... III-70

C.5.6 Field Equipment Calibration $\ldots \ldots \ldots \ldots \ldots \ldots \ldots \ldots$ III-71

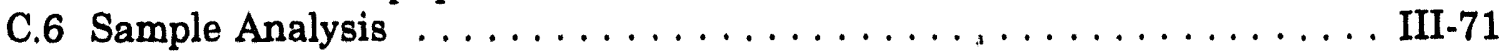

C.6.1 Sample Management . . . . . . . . . . . . . . . . . III-71

C.6.2 Sample Holding Times . . . . . . . . . . . . . . . . . III-71

C.6.3 Laboratory Analytical Procedures $\ldots \ldots \ldots \ldots \ldots \ldots \ldots$ III-72

C.6.4 Calibration of Laboratory Instrumentation . . . . . . . . . . . III-72

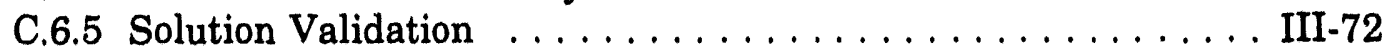

C.6.6 Reference Materials . . . . . . . . . . . . . . . . . . . III-72

C.6.7 Data Validation, Reduction, and Reporting ........... III-72

C.7 System Controls . . . . . . . . . . . . . . . . . . . . III-73

C.7.1 Document Control . . . . . . . . . . . . . . . . . . . III-73

C.7.2 Internal Laboratory Quality Control Samples $\ldots \ldots \ldots \ldots \ldots$ III-73

C.7.3 Control Charts . . . . . . . . . . . . . . . . . . . . III-73

C.7.4 Out-of-Control Conditions $\ldots \ldots \ldots \ldots \ldots \ldots \ldots \ldots$ III-74

C.8 Preventive Maintenance $\ldots \ldots \ldots \ldots \ldots \ldots \ldots \ldots \ldots \ldots$ III-74 
CONTENTS (Cont.)

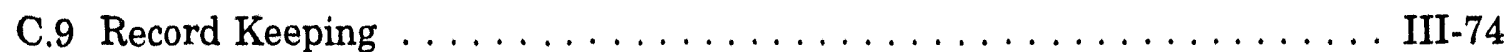

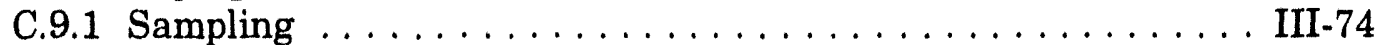

C.9.2 Laboratory Records . . . . . . . . . . . . . . . . . III-74

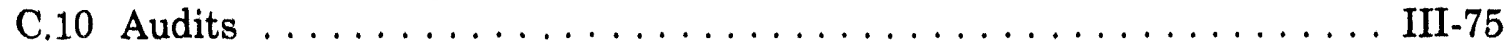

C.10.1 Field System Audits . . . . . . . . . . . . . . . . III-75

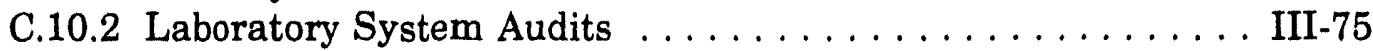

C.10.3 Performance Audits . . . . . . . . . . . . . . . . . . III-76

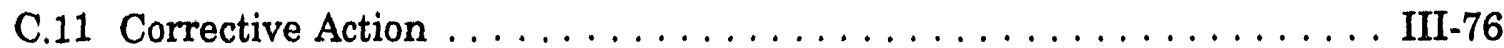

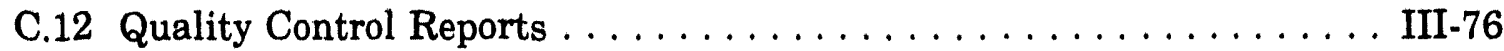

C.13 References ........................... III-76

APPENDIX D: Sensitive Environments Rating Values $\ldots \ldots \ldots \ldots \ldots \ldots \ldots$ III-77

APPENDIX E: U.S. Environmental Protection Agency Regional Biological

Technical Assistance Group Coordinators/Contacts . . . . . . . . . III-83

APPENDIX F: Glossary $\ldots \ldots \ldots \ldots \ldots \ldots \ldots \ldots \ldots \ldots \ldots \ldots$ III-87

\section{FIGURES}

A.1 Location of the Washbone Site $\ldots \ldots \ldots \ldots \ldots \ldots \ldots \ldots \ldots \ldots \ldots \ldots$ III-12

A.2 Staged Approach Proposed for the Washbone Site Ecological Risk

Assessment . . . . . . . . . . . . . . . . . . . . . III-22

A.3 Proposed Ecological Sampling Locations at the Washbone Site . . . . . . . . . III-30

\section{TABLES}

A.1 Contaminants of Potential Concern at the Washbone Site . . . . . . . . . III-14

A.2 Potential Ecological Receptor Groups for the Washbone Site Ecological Risk Assessment ........................... III-26

D.1 Sensitive Environments Rating Values $\ldots \ldots \ldots \ldots \ldots \ldots \ldots \ldots$ III-80 


\title{
WORK PLAN FOR CONDUCTING AN ECOLOGICAL RISK ASSESSMENT AT THE WASHBONE SITE, BURKE COUNTY, GEORGIA ${ }^{1}$
}

\author{
Prepared by: \\ BP \& V Associates \\ Wood Grove, Illinois \\ Prepared for: \\ U. S. Department of Energy \\ Washbone Site Remedial Action Project \\ Waynesboro, Georgia
}

May 1993

1 "Washbone" is a fictitious site. Information and format from several work plans in various draft stages have been used (i.e., modified or abstracted) to create this work plan example. 


\section{A.1 INTRODUCTION}

BP\&V Associates (BPV) has contracted with the U.S. Department of Energy (DOE) to conduct an ecological assessment of the Washbone site near Burke County, Georgia. This ecological assessment is part of a focused remedial investigation/feasibility study (RI/FS) of specific areas at Washbone that DOE used to dispose of radioactively contaminated processing wastes. This work plan describes the ecological risk assessment designed to (1) identify the pathways of contaminant transport in terrestrial, wetland, and aquatic systems on and adjacent to the site; (2) identify biota potentially at risk from exposure to the contaminants; and (3) determine whether existing contaminants pose an unacceptable ecological threat. The results of the ecological risk assessment will (1) help determine if any remedial action is necessary, and (2) determine whether the site supports a valuable and viable biological community. Remedial options will be evaluated separately in the focused FS for the site.

\section{A.1.1 Background and Site History}

The Washbone site is located north of Waynesboro in Burke County, Georgia (Figure A.1). In 1991, the Washbone site was added to the National Priorities List (NPL) because of the extensive disposal of machinery and processing wastes contaminated with thorium and uranium at the site. In addition, chemical wastes (organic solvents) were incinerated in open pits.

Surveys conducted from 1986 to 1988 by DOE demonstrated that soil and groundwater contamination had occurred at the site. Since 1988, DOE has been conducting a hydrogeologic assessment at the site to characterize the distribution and movement of contaminants in soil, surface water, and groundwater. Since placement on the NPL, all on-site studies are being conducted under CERCLA. At present, DOE has initiated its studies as part of an RI/FS.

Because the Washbone site is on the NPL, any remedial activities conducted there are subject to the provisions of the Comprehensive Environmental Response, Compensation, and Liability Act of 1980 (CERCLA) and its 1986 amendments (the Superfund Amendments and Reauthorization Act, or SARA). CERCLA requires that lead agencies respond to uncontrolled releases or potential releases of hazardous substances; and that responses be protective of human health and the environment. Remedial actions must protect ecological resources and must be based on some form of ecological assessment. Aàditionally, a number of applicable or relevant and appropriate requirements (ARARs), such as the Endangered Species Act, Clean Water Act, and various state laws, could require additional standards, actions, or limitations at hazardous waste sites.

Two major contaminated areas occur at the site: a trench where wastes were burned and a landfill used for waste burial. In-depth surveys of the types and extent of contamination at these locations are provided in reports by DOE $(1988,1990)$. 


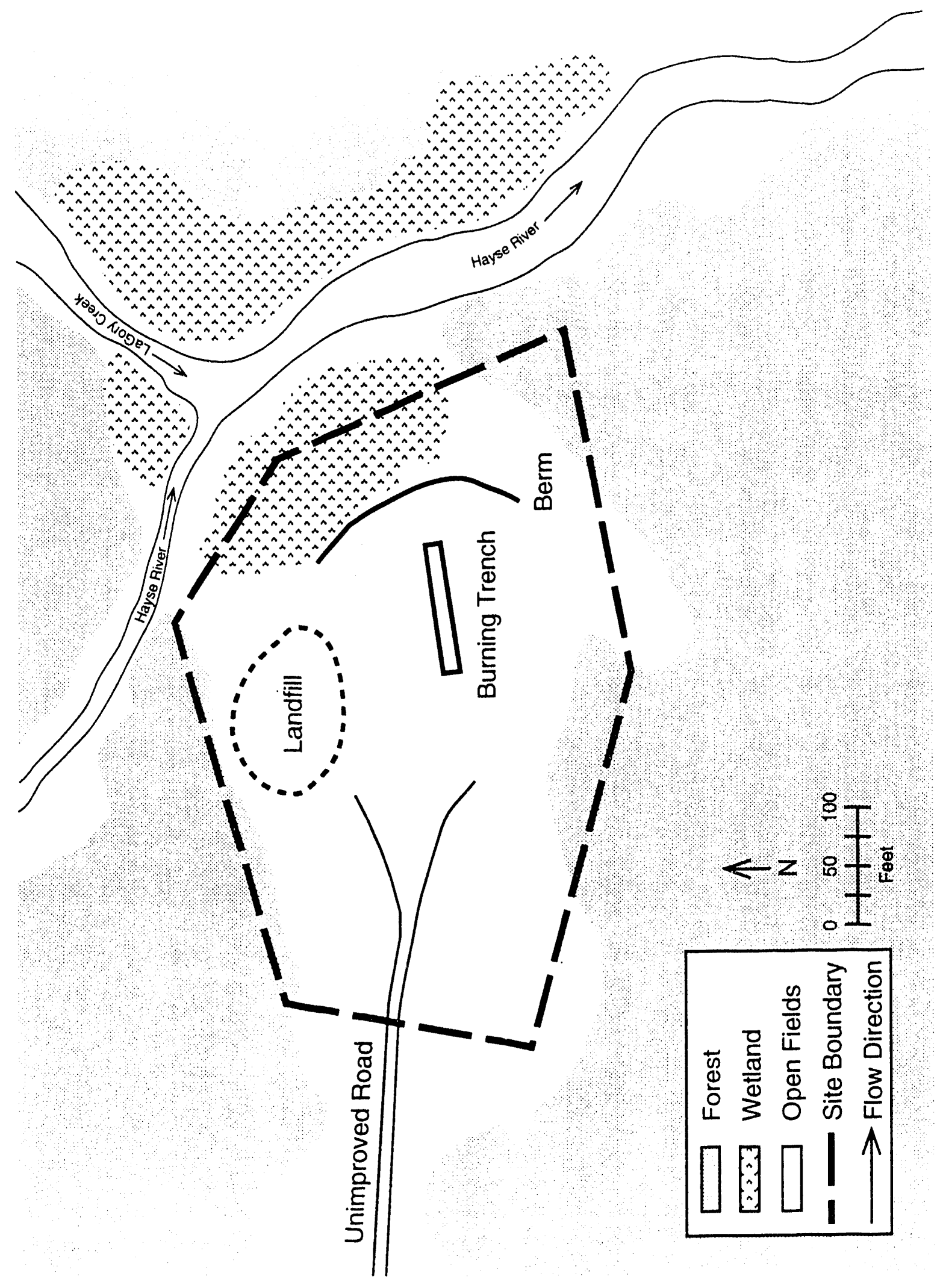

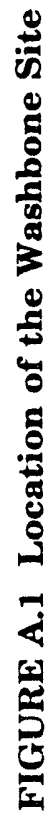


The trench area was used to dispose of drummed chemicals by burning. Some of the drummed chemicals (including chlorinated solvents such as trichloroethylene and polychlorinated biphenyls [PCBs]) are not highly flammable, and were probably incompletely burned. Thus, residues of some of the chemicals contaminated the soil, groundwater, and surface waters. A wetland adjacent to this pit could be contaminated by surface runoff and shallow groundwater movement. In addition, when this facility was being used, material from the pit was intentionally bulldozed into the wetland ("pushout area"). Preliminary data (DOE 1988) indicate elevated levels of metals and PCBs and other hydrocarbons in soils.

The landfill area was used to dispose of (by burial) empty or partially used containers, machinery, used spill containment materials, batteries, and other industrial waste materials. In addition to thorium and uranium, a variety of metals and organic contaminants occur within the landfill area at elevated concentrations (DOE 1990). Contaminant migration from the landfill may have affected nearby habitats.

A preliminary list of contaminants of concern for the site has been compiled in Table A.1 from data presented by DOE (1988, 1990). Detailed (quantitative) surveys of the biota that occur at the Washbone site and vicinity have not been conducted. Furthermore, no attempt has been made to assess the effects of contaminants on the biota within on- or offsite habitats.

\section{A.1.2 Physical Setting}

\section{A.1.2.1 Climate}

The Washbone site area has a modified continental climate characterized by moderately cold winters and warm summers. For the period 1975-1990, the monthly average temperatures vary from a high of $89^{\circ} \mathrm{F}$ in July to a low of $19.9^{\circ} \mathrm{F}$ in January. The prevailing winds in the area are from the south, with an average speed of $9.7 \mathrm{mph}$.

The normal annual precipitation is 33.9 in. Winter is the driest season, with an average precipitation of 6.3 in.; spring is the wettest season, with an average precipitation of $10.7 \mathrm{in}$. Snow occurs as early as October and as late as May, averaging $18.7 \mathrm{in./yr}$. Most snow falls from December through February. Thunderstorms are frequently associated with summer rains and are often accompanied by damaging rains. The frequency of thunderstorms recorded for the area is $37.4 \mathrm{~d} / \mathrm{yr}$.

Tornadoes may occur in the area once or twice per year, most often in April and May. Most have short and narrow paths and usually dissipate after a few miles. Only a limited number of tornadoes observed in the county have been associated with extensive damage or loss of life. 
TABLE A.1 Contaminants of Potential Concern at the Washbone Site

\begin{tabular}{lcc}
\hline & \multicolumn{2}{c}{ Site } \\
\cline { 2 - 3 } \multicolumn{1}{c}{ Contaminant } & Trench & Landfill \\
Area & Area \\
\hline Arsenic & & $\mathrm{X}$ \\
Cadmium & & $\mathrm{X}$ \\
Chlordane & $\mathrm{X}$ & \\
Chromium & $\mathrm{X}$ & $\mathrm{X}$ \\
Cyanide & $\mathrm{X}$ & \\
Lead & & $\mathrm{X}$ \\
Mercury & & $\mathrm{X}$ \\
PAH & $\mathrm{X}$ & $\mathrm{X}$ \\
PCB (Aroclor 1248) & $\mathrm{X}$ & $\mathrm{X}$ \\
Selenium & & $\mathrm{X}$ \\
Silver & $\mathrm{X}$ & $\mathrm{X}$ \\
Sulfate & $\mathrm{X}$ & $\mathrm{X}$ \\
Trichloroethylene & & $\mathrm{X}$ \\
VOC & $\mathrm{X}$ & $\mathrm{X}$ \\
\hline
\end{tabular}

a This list of contaminants is not inclusive.

b $\mathrm{PAH}=$ polycyclic aromatic hydrocarbon; $\mathrm{PCB}=$ polychlorinated biphenyl; $\mathrm{VOC}=$ volatile organic compound, including chlorobenzene, 1,1,2-trichloroethane, 1,1,2,2tetrachloroethane, vinyl chloride, trans-1,2-dichloroethylene, trichloroethylene, and tetrachloroethylene.

Sources: DOE (1988, 1990). 


\section{A.1.2.2 Geology and Soils}

The Washbone site is located in low limestone hills near the west bank of the Hayse River. The mid-Ordovician bedrock of the area is predominantly limestone and dolomite. In the upland areas, the bedrock is overlain by 10 to $40 \mathrm{ft}$ of unconsolidated materials consisting of alluvium, glacial drift, and weathered rock. Two distinct soil types occur in the area: loess deposits and residual soils that cover the upland regions and river alluvium found along the Hayse River and its tributaries. ${ }^{2}$

The principal surficial deposit on the upland surfaces is a silty clay soil developed from loess and deposited during and following the Wisconsin glaciation. A residual soil from weathering of limestone is present in some areas between the silty clay and bedrock.

Locally, the alluvium is composed of a surficial layer of $10 \mathrm{ft}$ of silt underlain by about $20 \mathrm{ft}$ of sand. The thickness of the silt layer increases toward the river. Beneath the sand, there is about $70 \mathrm{ft}$ of sand and gravel. This water-bearing alluvium is a major contributor to the domestic water supplies of nearby towns.

\section{A.1.2.3 Water Resources}

A.1.2.3.1 Surface Water Hydrology. The Hayse River borders the eastern and nc rtheastern edges of the site (Figure A.1). Most surface runoff from the site drains toward the east, although some surface runoff from the landfill area drains to the northeast. The northeastern portion of the site is largely an emergent wetland. The burning pit area at the site originally drained into the wetland. However, the berm created by the "pushout" has stopped surface water runoff from the pit area to the wetland.

A.1.2.3.2 Groundwater Hydrology. Groundwater in the vicinity of the site occurs in alluvium, fractured limestone and dolomite, and sandstone. Water-table conditions (unconfined aquifers) are typically found in areas of significant alluvial deposits; semiconfined conditions (confined to leaky aquifers) occur where layers of varying permeability are present. Flow in the limestone is primarily through secondary porosity provided by fractures and solution features. The St. Peter Sandstone, about $300 \mathrm{ft}$ below the site, contains a confined groundwater aquifer. The degree of connection between this aquifer and the overlying formations is not fully understood.

Over most of the site, groundwater flows primarily from west to east. Surficial groundwater flows into the site wetland and the second order stream that borders the site

2 Discussions of the stratigraphic column, geologic cross sections, and other pertinent geologic information (with associated figures) should be included. They are omitted from this work plan example for brevity. 
on the east. At the southern end of the site, the direction of groundwater flow is generally toward the south to the Hayse River.

Recharge to the bedrock in the vicinity of the site is limited to infiltration from precipitation or storm runoff. Discharge from the bedrock to the alluvium of the Hayse River floodplain may occur as springs, seeps, underflow, and flow to pumping wells. Recharge to the alluvial aquifer occurs primarily from the Hayse River and intermittent surface flooding, with minor amounts coming from infiltration and the underlying and adjacent bedrock.

\section{A.1.3 Ecology}

The site consists of open fields, second-growth deciduous forest (predominantly oaks, hickories, cottonwoods, and box elders), and wetlands (dominated by cattails); two streams border the east and northeastern portions of the site. A few areas of bare ground are located in the north central portion of the site, particularly in the vicinity of the disposal sites. Much of the land surrounding the site is state-owned wildlife area containing second-growth forest.

The biota at the site have not been surveyed in detail; however, common species are likely to include those typical to the surrounding wildlife areas. The Georgia Department of Conservation lists 23 amphibian, 42 reptile, 26 mammal, and 237 bird species for Burke County. Common mammal species include the eastern cottontail rabbit, opossum, raccoon, white-tailed deer, and several species of mice, voles, shrews, squirrels, bats, and foxes. Common reptile and amphibian species in the area include bullfrog, spring peeper, and a variety of salamanders, turtles, and snakes. About one-third of the bird species reported for the county nest in the area. Common birds in the area include a variety of warblers, sparrows, woodpeckers, red-tailed hawk, and American kestrel. Ten waterfowl species are common to abundant during the spring and fall migration, and a few species such as Canada geese, mallard, and wood duck nest or overwinter in the area.

The Georgia Department of Conservation lists over 100 species of fish for Burke County. On the basis of habitats and distributions of these species, the fish species that would most likely be abundant in the vicinity include gar, gizzard shad, carp, channel catfish, bluegill, largemouth bass, and a number of minnow and sucker species.

The Georgia Department of Conservation has identified 14 state endangered, 18 state rare species, and 13 other species as state watch list species or species of undetermined status for the county. Five of the state-listed species are also federal-listed as threatened or endangered, and another four are federal candidate (C2) species. However, no federally listed 
species, candidate species, or critical habitats have been identified by the U.S. Fish and Wildlife Service (FWS) as occurring at the site. ${ }^{3}$

Landsat ${ }^{T M}$ satellite data and digital photographic data have been combined to begin mapping of habitat types at the site and surrounding areas. ${ }^{4}$ This habitat mapping will continue, with finer resolution applied to the site area. Throughout this work plan, all spatial data, including water, soil, sediment, and biotic sampling locations, will be entered in a geographic information system (GIS). The GIS will allow a one-to-one mapping of contamination and ecological receptors to clearly show receptors and habitat types at risk to chemical stressors.

3 This section should also contain a table that provides the common and scientific names of the species and their federal and state status. Additional text should also be provided on reported sightings of these species in the immediate site vicinity or habitats in or near the site that may be suitable habitats for any of these species. These have been omitted from this work plan example for brevity.

4 A figure showing habitat types on and surrounding the site should be included. For brevity, this figure has not been included in this work plan example. 


\section{A.2 WORK PLAN RATIONALE}

Three types of information are needed to establish a relationship between the occurrence of hazardous wastes and contamination at the site and any ecological effects (EPA 1989a):

1. Chemical analyses of the appropriate media are needed to establish the presence, areal and vertical distributions, and concentrations of the contaminants;

2. Ecological surveys are needed to determine if adverse effects have occurred; and

3. Toxicity tests are needed to identify potential ecological impacts and to establish a link between any realized adverse ecological effects and the toxicity of the hazardous wastes and contaminants.

Data for item 1 above will be collected primarily by other groups involved in the overall site focused RI. The ecology risk assessment team (and any subcontractors) will be responsible for items 2 and 3 . However, successful completion of the risk assessment will require that all aspects of the effort (e.g., media sampling and biotic sampling) be fully integrated, both spatially and temporally (EPA 1989a).

Without these types of data, other potential causes of any observed ecological effects that are unrelated to the effects of the hazardous wastes and contaminants cannot be eliminated from consideration. For example, habitat disturbance or modification (e.g., conversion of forest habitat to a maintained grassy field) could have caused significant ecological effects, while contaminants may not be biologically available at concentrations that would result in any ecological impact.

The extensive movement of soil (from pushout activities) into the wetlands at the site has probably resulted in extensive sediment deposition in these wetland areas. Sediment deposited in an aquatic system changes the physical condition of the ecosystem and can dramatically alter the biotic composition in the affected area. This physical disturbance could easily confound the impacts caused by chemical contamination at the site. In addition, if much of the chemical contamination exists in groundwater that is not in contact with terrestrial or aquatic biota, impacts to ecological systems will not occur. Also, if the chemical contamination is sufficiently diluted as it is transported (especially in the groundwater) from source areas before it comes in contact with the biota, then ecological impacts could also be negligible.

Ecological effects of contaminants at the site will be estimated primarily at the population, community, and ecosystem levels of organization. Generally, ecological effects to individual organisms are only of concern if threatened or endangered species are involved (EPA 1989d). The FWS and the state of Georgia will be consulted before studies are begun of any listed species. 
Use of a "weight-of-evidence approach that considers all bioassessment results" has been suggested to analyze the current and/or future risks to the biota at the site. Such an approach is best achieved by examining the hierarchical structure of populations, communities, and ecosystems. For example, laboratory population level effects can be easily measured with controlled toxicity tests and other manipulated laboratory designs (Levin and Kimball 1984). These tests generally provide a rigorous evaluation of chemical effects. However, toxicity tests are often extrapolated directly to expected effects on natural populations. Such extrapolations are rarely accurate because individuals vary in their sensitivity and because individual and population interactions (which could mask or magnify laboratory inferences) are not considered (Bartell et al. 1992). Thus, it is imperative that risk assessments be considered according to the ecosystem, taking full account of spatiotemporal variability in the physicochemical environment and how such variability might alter rates of ecological processes that determine population exposure to toxic compounds (Levin et al. 1989; Bartell et al. 1992).

In addition, remediation of hazardous waste sites necessarily involves the manipulation of community and ecosystem parameters that could incidentally affect these higher levels of organization. Thus, an ecological assessment must determine if these higher levels of organization have been affected by hazardous substances or physical disruption (NAS 1975; Levin and Kimball; Levin et al. 1989). In addition, measurements of community and ecosystem parameters can be accomplished in situ at the site and at reference locations, producing relatively direct measurements of differences among sites. If community or ecosystem structure does not differ between the site and a reference location; results from laboratory or other controlled toxicity tests would not provide sole justification to remediate on the basis of ecological considerations at the site.

At the community level, the main indicators of differences among sites include shifts in species dominance and diversity (including richness). Such shifts could be tied both to ecosystem functions (e.g., changes in density, biomass allocation, reproductive effort). Similarly, changes at the population level could be a direct result of contamination (e.g., species-specific toxicity) or an indirect result of changes in ecosystem or community processes (e.g., impacts to predators or prey). Because ecological sampling will be conducted at several locations over time, spatial and temporal variation in biotic and abiotic parameters can be detected. Evaluation of these variations will lead to a rigorous ecological risk assessment and result $\mathrm{n}$ a comprehensive appraisal of the importance of contaminants to ecosystem, community, and population factors at the site. 


\section{A.3 STUDY APPROACH AND DATA REQUIR,EMENTS}

On the basis of preliminary data regarding site contaminant distribution and site biota and habitat distributions, a three-phased approach will be taken in further defining contaminant toxicity and exposure assessments. The rationale for this approach is based on an incomplete database regarding: the locations and areal extent of the contaminants, ecological receptors, and the potential for bioaccumulation or food chain transfer. First, contaminant concentrations from on-site and off-site media will be determined to identify areas that warrant the collection of additional field and chemical data. Essentially, Phase 1 will identify "hot spots" of radiological and chemical contamination. Phase 2 will include ecological surveys, toxicity screening, and chemical and radiological analyses at the hot spots identified in Phase 1. Phases 1 and 2 will be conducted as part of Stage 1 of the ecological risk assessment (Figure A.2). The results of Phase 2 will be used to identify those hot spots for which refined toxicity tests and in-depth ecological assessments will also be required. These refined toxicity tests and in-depth ecological assessments will constitute Phase 3 . Phase 3 will be conducted as part of Stage 2 of the ecological risk assessment (Figure A.2). Given the nature of the contaminants and degree of contamination, reference areas will be selected and sampled as a basis for comparison with contaminated sites. ${ }^{5}$

The ecological risk assessment will be conducted in three stages (Figure A.2) to evaluate the effects of leaving the contaminated site in its present condition. Thus, Stage 1 will involve the initial determination of the current condition of a selected number of ecological parameters. The baseline condition of the site will be compared with ecological and physicochemical conditions at selected reference areas. Stage 1 of the ecological assessment essentially includes Phase 1 and 2 activities previously described. If the baseline condition is not different from that at the reference areas, or does not exceed ecological ARARs or other risk-based standards, the extensive analytical and toxicological tests that constitute Stage 2 of the ecological risk assessment may not be needed. The ecological assessment team then vill recommend that extensive remediation is not warranted for the site based on ecological conditions. If ecological differences between the site area and selected reference background sites are noted and these differences can be reasonably attributed to chemical or radiological stressors rather than physical disturbance, or if ARARs or risk-based standards are exceeded, in-depth analysis will be completed in Stage 2 to determine the type of stressors and the current and future risk to ecological resources. Stage 2 essentially includes Phase? activities described initially in Section A.3.

Stage 1 work will be coordinated with the physical media (sediment, soil, and water) sampling being done to provide site characterization in support of the remedial investigation for the site. (Appendix B provides an annotated outline for an ecological field sampling plan.)

\footnotetext{
5 A brief mention of the reference site(s) should be included here.
} 


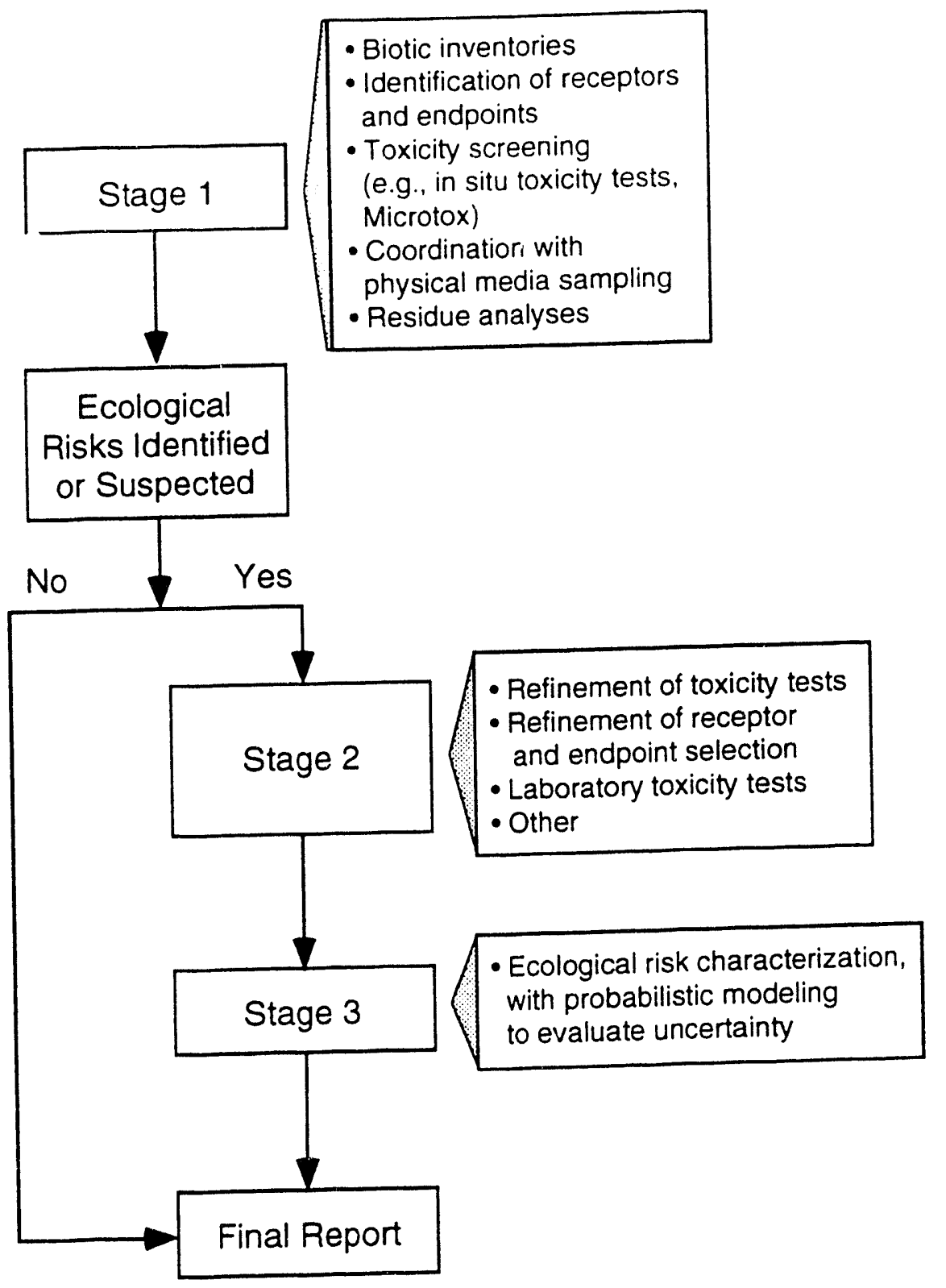

FIGURE A.2 Staged Approach Proposed for the Washbone Site Ecological Risk Assessment (Phases 1 and 2 of the field and laboratory investigations will be conducted during Stage 1; Phase 3 will be conducted during Stage 2.) 
Stage 1 will also include surveys (i.e., sampling) of terrestrial, wetland, and aquatic biota. These surveys will be conducted for: (1) upland and wetland vegetation (herbaceous species, shrubs, and trees), (2) invertebrates (aquatic macroinvertebrates and soil invertebrates), (3) fish, (4) amphibians and reptiles, (5) birds, and (6) mammals. The field sampling plan describes survey methodologies. In some instances, sampling emphasis would be focused on a particular species or species group (e.g., insectivorous mammals) (see Section A.3.1 Receptors and Endpoints). These surveys will be compared with similar surveys at the selected reference sites. Media concentrations of hazardous substances at the site will also be compared with concentrations at reference sites, background areas, or other hazardous waste locations. Section A.4.1 discusses the methodologies to be used to obtain data for Stage 1 , as well as how data will be compared between the Washbone Site and reference sites.

Stage 2 will be initiated if additional ecological surveys and toxicological assessments are needed. For this phase, more detailed data will be gathered for media and biota, both from the site and from the reference sites. Section A.4.2 provides more detailed information on activities and analyses to be conducted for Stage 2 .

In Stage 3, field data and results from toxicological studies in Stages 1 and 2 will be used to characterize ecological risks at the site. Much of the determination will be based on comparisons or reference or background sites to the site. Differences found between reference samples and site samples do not necessarily indicate problems from contamination. To evaluate these potential differences, BPV will use results from all the ecological surveys, toxicity tests, bioassays, and residue analyses to determine ecological effects. BPV will use EPA guidance for the risk assessment and, specifically for the ecological assessment, will use the guidance directed at CERCLA cleanup actions (EPA 1989a-c, 1991a).

A classic experimental design developed for statistical analyses requires random selection of control and experimental areas. Because the locations of contaminated areas at the site have already been determined by past activities, such an experimental design is not possible for the ecological assessment. Thus, many classic methods of hypothesis testing, such as analysis of variance, are severely restricted in use, interpretation, and inferences of causality (Stevens 1988). Because receptors located in a contaminated area and receptors located in the reference study area may not be from the same randomly chosen population of all receptors at or near the site, the key assumption about sampling a normally distributed group may be violated. Such a violation invalidates the statistical analysis of a "treatment effect" of chemical contamination on ecological processes. However, the hypothesis that the endpoints or measurements within the contaminated area are different than those found in the uncontaminated areas can be tested. Although differences do not imply causality, a set of differences can be used to infer that adverse effects are occurring in the environment.

The assessment process described in this work plan will provide:

- Baseline data on the status of the biota at the site,

- Estimates of the ecological effects of contaminants, 
- Estimates of habitat alteration or modification from physical disturbances at the site,

- Identification of the extent to which effects have resulted specifically from radiological and chemical contaminants at the site.

To assist in formulating and refining the objectives of this ecological risk assessment, the BPV ecological risk assessment team will consult with appropriate federal and state agencies concerned that site response actions address ecological concerns. These consultations will include the regional Biological Technical Assistance Group (BTAG), which consists of officials from the EPA and other agencies that are "natural resource trustees" under Superfund (e.g., U.S. Department of the Interior). The main functions of the BTAG are to (1) provide a forum for communication among agencies; (2) identify ecological concerns; (3) determine data needs; and (4) make recommendations, including suggested monitoring and assessment activities, sampling plans, analytical techniques, ecological endpoints, ecologically based ARARs, and beneficial and detrimental aspects of possible remedial actions (EPA 1989c).

\section{A.3.1 Ecological Receptors}

Because of the diversity of habitat types at the site (forest, old field, wetland, and stream), the complexity of an ecological risk assessment is readily apparent. One approach to developing such an assessment is to define a number of potential receptor species for each habitat type. Ecological receptors are biotic species selected as "indicators" to determine if contaminants are having a demonstrable effect on biotic communities. Species are selected as ecological receptors on the basis of their trophic level, habits, regulatory importance, and/or commercial and recreational importance. The selection of species as trophic-level indicators would depend on the contaminant of concern. For contaminants known to biomagnify (e.g., mercury), species at the top of the food chain (e.g., predators) would be likely candidates. However, for most metals and other contaminants that do not demonstrate biomagnification, plant species, herbivores, or detritivores would be selected as receptor species. An ecological receptor chosen for its habitat would be a species whose life history places it in direct contact with contaminants. Such species include those inhabiting and/or feeding within or upon sediments or soils (e.g., earthworms, amphipods, benthic insect larvae, tadpoles, bottom-feeding fish).

Species of regulatory importance include federal- and state-listed species. Under most situations, a surrogate species would need to be chosen for any field work conducted to determine ecological risks to a listed species. For example, a common minnow species with habitat requirements and/or prey base similar to a listed minnow species could be used for in-site caged toxicity tests.

Species of commercial or recreational importance are often chosen as ecological receptors because of their importance to man (e.g., econornic and health concerns). Often, a 
species of recreational or commercial importance also has trophic or habitat characteristics that make it an ideal candidate as an ecological receptor (e.g., game fish and waterfowl).

Species generally appropriate as receptor species are listed in Table A.2. The final choice of receptors will be determined following initial ecological reconnaissance of the site to determine specific species from Table A.2 that are common to the site.

\section{A.3.2 Systems Model and Pathway Analysis}

The ecological assessment is an integral part of the ongoing and planned remedial activities at the site. As an aid in the integration of all activities, a systems model(s) will be developed to examine the connections between chemical fate and ecological effects. ${ }^{6}$ The model(s) will show how the fate of contaminants is linked to the ecological receptors, assessment endpoints, and measurement endpoints. The systems model(s) will address environmental pathways (e.g., contaminated sediment and benthos) to simulate potential ecological risk. Modeling is particularly important for those species for which field sampling or toxicity testing cannot be done (e.g., threatened and endangered species).

The development of ecological models will be based on survey and inventory data and the information obtained from the statistical analyses of the field and experimental studies at the site. Those studies will determine parameter values for the models. In addition, BPV staff will rely on literature values for ecosystem parameters, especially for toxicity values, bioaccumulation factors, and physical parameters (e.g., soil and sediment properties). The field studies will assist in determining the variation, or range of values, for parameters and variables in the models. By acquiring information on the range of conditions found at the site, we can explicitly incorporate the variance of the ecological conditions. This variance is a normal property of ecological systems and could have a major effect on decision making for remedial actions.

\section{A.3.3 Published Standard Methods and Protocols}

Methods and protocols (including field sampling methods, material handling, laboratory assays, and data analyses) used in all tasks associated with the ecological risk assessment will follow published standard methods or guidelines where practicable and appropriate. Standard approaches for toxicity testing include those proposed by the American Society for Testing and Materials (ASTM 1992) and discussed in Section A.4.1.4. Unlike the

6 The choice of applicable systems models to use needs to be determined on a site-by-site basis; depending upon site features, contaminants, contaminated media and habitats, and biota. The U.S. Environmental Protection Agency, Office of Health and Environmental Assessment (OHEA), Exposure Assessment Group, Washington, D.C., has sponsored the development of EML/IMES (Exposure Models Library with the Integrated Model Evaluation System). EML/MMES contains over 60 models which may be used for exposure assessments and fate/transport modeling. Further information on EML/MES can be obtained from the OHEA by calling 202-260-8922. 
TABLE A.2 Potential Ecological Receptor Groups for the Washbone Site Ecological Risk Assessment

\begin{tabular}{|c|c|c|}
\hline Species (or group) & Rationale & $\begin{array}{l}\text { Assessment and/or } \\
\text { Measurement Endpoints }\end{array}$ \\
\hline $\begin{array}{l}\text { Terrestrial plants } \\
\text { Woody species } \\
\text { Herbaceous species }\end{array}$ & $\begin{array}{l}\text { Long-term indicator } \\
\text { Short-term indicator }\end{array}$ & $\begin{array}{l}\text { Percent cover } \\
\text { Production } \\
\text { Percent cover }\end{array}$ \\
\hline $\begin{array}{l}\text { Aquatic plants } \\
\text { Duckweed }^{\mathrm{a}} \\
\text { Cattail }\end{array}$ & $\begin{array}{l}\text { Short-term indicator } \\
\text { Dominant species }\end{array}$ & $\begin{array}{l}\text { Production } \\
\text { Production }\end{array}$ \\
\hline $\begin{array}{l}\text { Terrestrial invertebrate } \\
\text { Earthworms }\end{array}$ & Direct contact with soil & $\begin{array}{l}\text { Population size } \\
\text { Distribution }\end{array}$ \\
\hline $\begin{array}{l}\text { Small mammals } \\
\text { Local indicator }\end{array}$ & Short-term indicator & $\begin{array}{l}\text { Population size } \\
\text { Diversity }\end{array}$ \\
\hline $\begin{array}{l}\text { Birds } \\
\text { Predatory } \\
\text { Aquatic }\end{array}$ & $\begin{array}{l}\text { Ecological "integrators" } \\
\text { Integrators }\end{array}$ & $\begin{array}{l}\text { Population size } \\
\text { Population size }\end{array}$ \\
\hline Amphibians $^{a}$ & Short-term indicator & $\begin{array}{l}\text { Diversity } \\
\text { Population size } \\
\text { Development }\end{array}$ \\
\hline Fish $^{\mathrm{a}}$ & $\begin{array}{l}\text { Commercial and } \\
\text { recreational importance }\end{array}$ & $\begin{array}{l}\text { Diversity } \\
\text { Age-structure }\end{array}$ \\
\hline $\begin{array}{l}\text { Invertebrates } \\
\text { Benthic insects }\end{array}$ & $\begin{array}{l}\text { Short-term indicator, } \\
\text { sediment contact }\end{array}$ & $\begin{array}{l}\text { Diversity } \\
\text { Population size }\end{array}$ \\
\hline
\end{tabular}

a Representative species from these groups are also utilized in laboratory and field toxicity tests. 
case for human health risk assessments, ecological risk assessment methods have not been standardized. The selection of appropriate methods and assumptions is a matter of much debate. Nonetheless, some generalities can be drawn, especially with respect to choice of receptor species and $€$ ndpoint determinations. The BPV ecological field sampling plan and quality assurance project plan (QAPP) provide further details on standard methods and procedures. (Appendixes B and C provide annotated outlines for an ecological field sampling plan and a QAPP, respectively). Guidance will also be drawn from other relevant sources, including the EPA (1989a-d, 1991a)

All tasks undertaken by subcontractors will also follow accepted and standard methods. Additional information on chain-of-custody procedures and quality assurance/ quality control (QA/QC) are provided in the QAPP.

\section{A.3.4 Literature Search of Toxic Effects of Known Contaminants at the Site}

Field data, monitoring information, and toxicity-testing results of contaminated media generally are more beneficial and reliable than estimates made from literature reviews (EPA 1989c). However, published studies can be useful in deciding (1) types of toxicity tests (e.g., acute or chronic) to be conducted with field-collected samples, (2) kinds of organisms to be tested, (3) effects to be expected, and (4) how toxicity tests should be interpreted (EPA $1989 \mathrm{c})$. BPV will gather information from the literature on the relative toxicity of elements or compounds to various biota (e.g., mammals, fish, invertebrates, or plants) and on contaminant fate in the environment. Also, an in-depth review of the literature will help restrict the screening of organisms to those few species that might be good indicators of habitat modifications. This literature review could lead to use of procedures that would be economical of time and funds (EPA 1991b). A search of the literature could also be beneficial in the identification of data gaps regarding the effects of a particular contaminant to biota. 


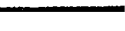




\section{A.4 SCOPE OF PROPOSED TASKS}

Tasks for each planned stage are defined in the following subsections. The study scope may change on the basis of preliminary results from field and laboratory testing obtained in the tasks for each phase.

\section{A.4.1 Stage 1 Task Descriptions}

The tasks described below include field assessments, toxicity assessments, and ecosystem modeling to evaluate potential ecological risks at the site. BPV considers these approaches to be complementary rather than separate assessment methodologies.

\section{A.4.1.1 Identification of Site Sampling Locations}

The sampling program for the ecological risk assessment will be coordinated with the physical characterization being conducted as part of the overall RI effort at the site (BPV 1992). This will be necessary to minimize statistical variability in the analytical results associated with site differences at the site and with temporal changes in chemical concentration, fate, or toxicity.

Previous media sampling of groundwater, surface water, and soil conducted by DOE $(1988,1990)$ in the site area provides a preliminary determination of the spatial extent of chemical contamination. However, the transport and fate of the contaminants at each potentially contaminated area have not been documented. The incompleteness of the data suggests that ecological sampling should focus on areas in and around the contaminated areas and in terrestrial, wetland, and aquatic ecosystems.

Figure A.3 shows the areas proposed for ecological sampling. The areas include up- and downgradient locations from each disposal area at the site. Within these locations, samples of environmental media and biota will be collected concurrently to ensure statistically and ecologically valid comparisons of the sampling results. The ecological field sampling plan (BPV 1993a) provides detailed information on the location and number of physical media samples. The ecological assessment will use these locations to ensure that biological samples match media sampling. In addition, all in-situ analyses will be conducted at these locations. A grid will be positioned at each area, and a subset of locations within the grid will be randomly chosen for sample collection. An appropriate number of collections will be chosen to ensure that standard errors will be minimally affected by sample size, thus reducing statistical uncertainty. In addition, the appropriate number of random locations will permit use of simpler, more straightforward test statistics than would be possible with a smaller sample size. 


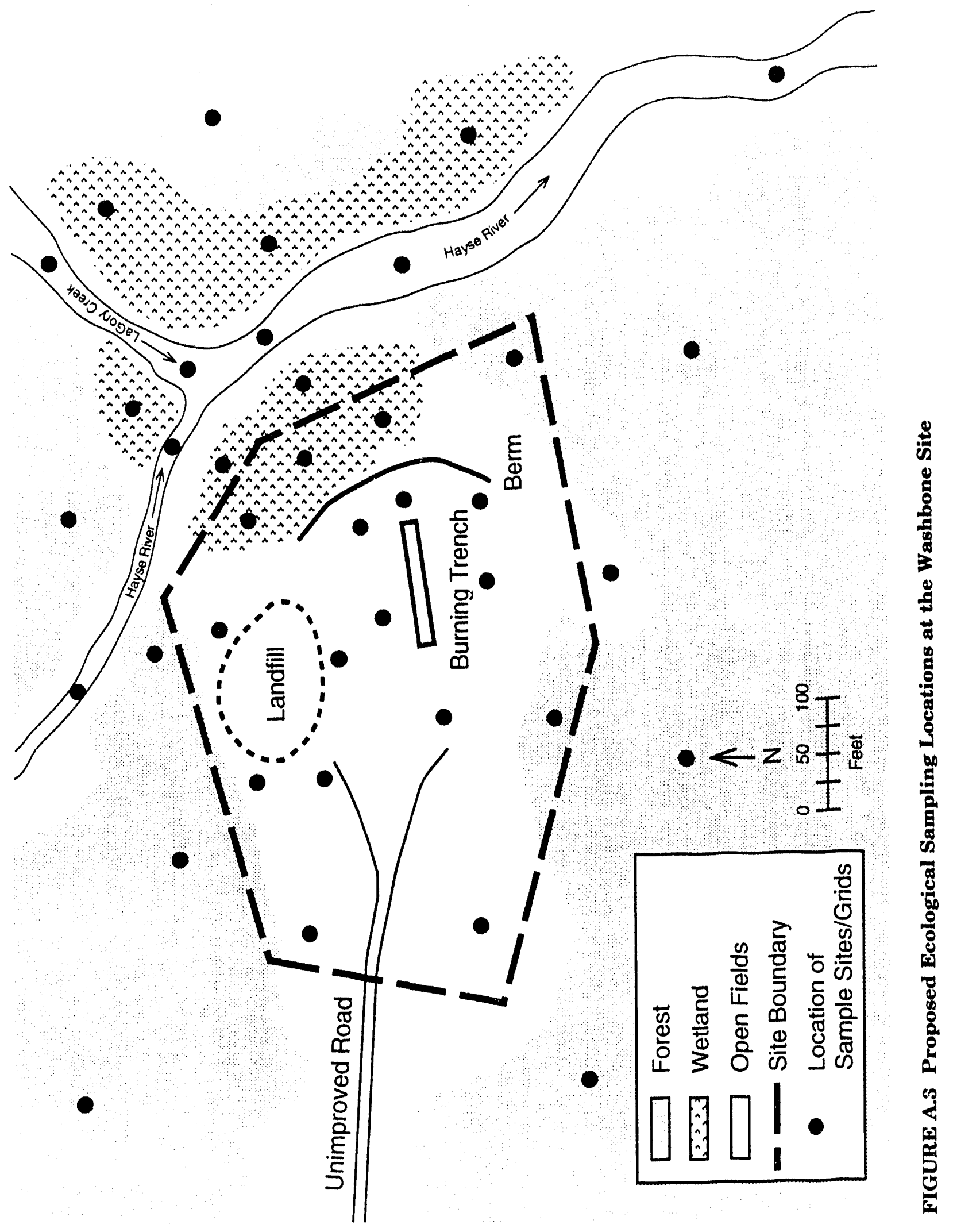


Because of the physical disturbance in the pit areas (e.g., excavation and vehicle disturbance), the up- and downgradient locations must be situated so that the spatial heterogeneity of the disturbed areas does not interfere with or confound the sampling results. For example, bare areas around the disposal areas must be compared with other bare areas, and downgradient forested or wetland habitats must be compared with similar upgradient or reference site habitats. Most of the field sampling program will be directed at thorough investigations of the extent of contamination and effects to wetland, stream, and late successional terrestrial communities. The final locations selected for ecological field sampling will depend on BPV media sampling work to delineate the locations of the disposal area contaminants.

\section{A.4.1.2 Reference Site Selection}

Essential to interpretation of endpoints or measurements in a sampling program is the selection of appropriate reference sites (Stevens 1988; Hunsaker et al. 1989; Orvos and Cairns 1991). For this assessment, reference sites will be uncontaminated locations that have habitat and hydrologic characteristics similar to those in potentially contaminated areas of the site. To test for differences between sites due to contaminants, contaminated and reference locations must have similar properties, including topographic conditions, landscape shape and size, soil and sediment properties, habitat type, and habitat disturbance. ${ }^{7}$

\section{A.4.1.3 Field Sampling}

BPV will conduct field sampling of flora, fauna, soils, sediments, and surface waters at on-site locations (including bordering streams) and reference locations. Sampling protocol is discussed in Section A.6. On-site and reference locations will be matched as closely as possible in terms of all relevant ecological factors to permit appropriate comparisons. On-site areas sampled at the site will include forest, old-field habitat, bare/sparsely vegetated areas, marsh, and stream habitats.

BPV will use initial biotic surveys and sampling at these locations, in part to identify appropriate ecological receptors. For Phase 1, all on-site samples will be collocated with samples of soil, sediment, and water (BPV 1992). Sampling sites at reference locations will be selected on the basis of similarity of habitats and hydrology to the site locations.

The field sampling approach has been designed to evaluate in situ comparisons between the site and the reference locations. These comparisons will form the background under which controlled testing and analysis will be judged within the ecological risk assessment. Specific toxicity tests, residue analyses, microcosm analyses, or field experimentation (e.g., caged studies) described in other sections of this document are used to focus attention on explicit ecological factors (i.e., test organisms) or areas of contamination.

7 A discussion (and accompanying figure, if appropriate) would be included on the reference site(s). For brevity, it is not included here. 
BPV will use these explicit tests to make the connection between a specific chemical(s) and a narrowly defined ecological response. Thus, use of toxicity tests, residue analyses, or other controlled studies will reduce potential uncertainties in the field sampling and analysis.

A.4.1.3.1 Population Parameters. The major population parameters to be estimated include species density(number of individuals per unit area), plant cover(areal coverage for a species within a unit area of habitat), and plant biomass (plant weight per unit area). Readily detectable differences in individual size classes between receptor populations at the site and the reference sites could suggest some important abiotic ecosystem differences among or within those sites. These data will permit comparison of species performance among sites.

A.4.1.3.2 Community Parameters. Three important community parameters, readily measured from field sampling, are (1) species dominance (or relative rank of species on the basis of numbers or biomass), (2) diversity(consideration of both the number of species and the distribution of individuals among the species), and (3) community similarity (comparison of both the similarity in composition and the similarity in number of individuals per species between sites). Shifts in species dominance and diversity have long been used as indicators of pollution or other anthropogenic disturbance.

A.4.1.3.3 Ecosystem Parameters. Ecosystem field studies are conducted to detect effects that might be undetected in population or community studies or in simplified systems (NAS 1975; Kimball and Levin 1985). As alluded to above, impacts observed at one ecological level (e.g., population) do not translate readily into effects at another level (e.g., ecosystem) (Kimball and Levin 1985). Furthermore, chemicals that appear to be safe in single-species toxicity tests can be transformed under field conditions and cause toxic effects (Kimball and Levin 1985).

An important ecosystem measure for hazardous waste sites is actual or potential biomagnification of hazardous substances. To evaluate magnification, BPV will conduct analyses to determine if site contaminants move through the food chain or if uptake in vegetation represents a significant ecological problem at the site.

\section{A.4.1.4 Preliminary Toxicity Tests}

During Phase 1 of Stage 1 (Figure A.2), BPV will conduct preliminary screening assessments of media toxicity at the site for terrestrial and aquatic organisms. The media to be tested will be collected from sites known to be contaminated. BPV will use toxicity tests on soils, sediments, and water to (1) determine the relationship between toxicity and media concentrations, (2) investigate interactions among contaminants, (3) determine spatial and temporal distribution in contamination, (4) rank areas for remedial action, (5) estimate the effectiveness of management and remedial options, and (6) identify areas of contamination 
for further investigation (Ingersoll 1991). Furthermore, such tests can supplement chemical residue data in determining remedial actions and may be more sensitive to low levels of contamination than other monitoring methods. Also, these media tests can indicate toxicity of mixtures of contaminants more readily than can single-chemical criteria (EPA 1989a). Because not all species are equally sensitive to contaminants, a number of toxicity tests ${ }^{8}$ involving individual species from different trophic levels would be required to fully assess soil, sediment, and water quality (Ingersoll 1991). Ecological surveys will also be used to assess effects; therefore, multispecies tests should not be necessary to test for higher level ecological effects. Several sensitive single-species tests are often adequate to identify sources and probable causes of toxicity at hazardous waste sites (EPA 1989d).

A.4.1.4.1 Terrestrial. Several tests are available for rapid assessment of soil toxicity. The most widely used terrestrial target organisms are earthworms and plant seedlings (Karnak and Hamelink 1982; Wang 1986a; Wang et al. 1990; Callahan et al. 1991; Carlson et al. 1991; Gorsuch et al. 1991). Earthworms and seedlings (e.g., lettuce, radish, and/or sedge) will be grown in soil samples collected from random locations within grids established at the site and reference locations. An additional set of controls will be grown in laboratory control soil. BPV will conduct in-field bioassay tests of earthworms at upland locations (e.g., up- and downgradient of the disposal sites) to determine the spatial pattern of potential soil toxicity (Menzie et al. 1992). Appropriate Microtox toxicity tests will also be conducted at these locations (see Section A.3.1.2 for further detail).

Assessment of invertebrates (e.g., species diversity and other community parameters) within the soil below the litter layer is another initial screening method that will be used to infer or indicate the potential for upland soil contamination at concentrations that may be toxic to biota (Menzie et al. 1992). This assessment will be conducted at upland grid locations. Small wooden boards will be placed on the ground; after several days, they will be overturned and invertebrates under the boards will be collected, identified, and counted. This method is rapid and inexpensive.

Other studies have used captured animals from contaminated and uncontaminated areas to assess toxicity by comparing tissue levels of contaminants and survivorship curves (e.g., Rowley et al. 1983). Whole-body and tissue contaminant (residue) analyses will be initiated after media analyses indicate potential contaminants and locations of concern vis-avis bioaccumulation. Therefore, these residue analyses will be performed late in Phase 1.

Massive mortality or the absence of expected species from a community can suggest the occurrence of lethal levels of exposure to a contaminant. However, tissue or whole-body analyses (plant or animal) can identify sublethal and chronic, low-level exposure to a source of pollution (EPA 1991). In conjunction with soil, sediment, and water analyses, determination of contaminants in biota would permit a determination of bioconcentration,

8 The procedures for conducting the toxicity tests would be fully detailed in the QAPP (as appendixes to that document). An annotated QAPP outline is included as Appendix C. 
bioaccumulation, and biomagnification potential of the contaminants of concern within the site. Generally, soil- or sediment-inhabiting organisms have higher tissue concentrations of contaminants (particularly metals) than other organisms. However, some contaminants (particularly those that are lipophilic, such as mercury and organic materials) tend to biomagnify. Therefore, species at higher trophic levels tend to display greater concentrations of such contaminants. Certain species from various habitats or trophic levels would be selected (on the basis of the preliminary literature review) to assess contaminant levels in biota. Biotic contaminant analyses would involve organs or tissues in which contaminants of concern are known to accumulate (for sublethal or chronic assessments) and whole body concentrations (for trophic analysis assessments).

Species selected for toxicity tests could also be used for in situ bioconcentration analyses. Aquatic macrophytes, macroinvertebrates, amphibians, bird eggs or young, and small mammals are preferable organisms for assessment of short-term exposures to contaminants; whereas, fish, reptiles, woody plants, large adult birds, and furbearers or large game mammals may be more suitable for monitoring long-term exposures (Leibowitz and Squires 1991).

A.4.1.4.2 Wetlands and Streams. Tests intended to provide a preliminary indication of the toxicity of site media to aquatic biota will analyze sediments and interstitial and overlying (open) waters. Sediment-dwelling biota can be exposed to contaminants from all three of these media. Additionally, feeding habits can influence the contaminant dose. For many benthic invertebrates, the toxicity and bioaccumulation of sediment-associated contaminants such as metals and nonionic organic materials have been correlated with the concentration of these contaminants in interstitial waters rather than with sediment-bound concentrations.

As feasible, guides and practices for sediment and water toxicity testing accepted by the ASTM (e.g., 1992) will be followed. These guidelines and practices include choices of biotic species for testing and sample collection, handling, and testing procedures. Other supplemental tests and species appropriate to physical, chemical, and biological conditions at the site would also be considered. Appropriate agencies (e.g., the EPA) would be consulted before such tests were undertaken.

The following paragraphs discuss various test methods and/or biotic species suitable for preliminary toxicity testing of wetland and stream sediments and waters. Methods to assess the toxicity of freshwater sediments are discussed by Burton (1991).

Amphipods are appropriate species for sediment toxicity testing because they are ecologically important, have a wide geographic distribution, are easy to handle in the laboratory, and are highly sensitive to contaminated sediments (ASTM 1990b). Test results will be based on mortality and sublethal effects, such as emergence from sediment and inability to bury in clean sediment following exposure to test sediment. 
The Microtox Toxicity Test System ${ }^{\mathrm{TM}}$ and associated Microtox Solid-Phase Test ${ }^{\mathrm{TM}}$ will be used to detect and measure the toxicity of water and sediments, respectively. Although not definitive, the Microtox test systems can provide initial screening of media toxicity within a relatively short time. When used in conjunction with other toxicity screening tests during Stage 1, the Microtox test systems should provide results indicating which media and sites require refined toxicity testing during Stage 2 and results permitting initial comparisons among sites.

A phytoplankton assay (algal growth bioassay) will be conducted using Selanastrum capricornutum. This test is one of the few recognized methods for testing toxicity to aquatic primary producers. This test compares both biomass and chlorophyll $a$ content as measures of algal growth. In addition to tests using freshwater al rae, growth of Lemna sp. (duckweed) or other free-floating plant species also will be used to monitor tissue uptake from water and to conduct chronic toxicity tests. Use of only an algal species or a vascular plant species is not as sensitive for screening contaminants as is use of both plant types (Fletcher 1990). Unlike rooted vascular plants, which have been shown to have unsatisfactory correlations for biomonitoring of sediment-bound metals (Outridge and Noller 1991), free-floating vascular plants have been shown to be reliable indicators of water pollution. Culture and experimental conditions will follow published methodologies (e.g., Wang 1986b; Fletcher 1990; Cowgill et al. 1991). Testing endpoints would include reduction in number of plants, fronds, or dry weight.

In situ (caged) toxicity tests will be conducted with fish, tadpoles, crustaceans (e.g., crayfish), clams, snails, rooted or floating vascular plants, or other species that can readily be maintained in a partially enclosed test chamber under field conditions. Endpoints will include such parameters as growth, survival, deformities, and contaminant uptake. Final selection for in situ caged studies will be determined following initial ecological reconnaissance of the site and the reference sites. To avoid introducing species not presently established (i.e., exotics) in the area, only species indigenous to the sites would be used. (Note: If excess mortality at control sites is observed [usually $>10 \%$ ], the results of in situ test results should be used with caution, if at all.)

In summary, BPV will use a battery of screening evaluation bioassays to determine if sediment and water at the site are toxic to terrestrial, wetland, and stream biota. Toxicity tests used will be simple, reproducible, inexpensive, ecologically relevant, and relevant to regulatory criteria (Giesy and Hoke 1989). From the discussion above, it is evident that several test organisms and techniques are suitable for toxicity testing of soil, sediment, and water. A final selection or refinement of proposed tests will be made on the basis of discussions with various federal agencies (e.g., member agencies of the regional BTAG), results of biotic surveys at the site, and published papers. 


\section{A.4.1.5 Summary of Stage 1 Approach and the Need for Further Investigation}

In summary, Stage 1 of this ecological risk assessment will concentrate on several activities: (1) quantitative inventory of the biota from the different habitats and/or ecosystems at the site and selected reference areas; (2) identification of potential receptor species; (3) identification of appropriate assessment and measurement endpoints; (4) performance of in situ and, if feasible, laboratory toxicity tests of soil, sediment, and surface water; (5) residue/tissue analysis; and (6) construction of a systems model for the site.

The completion of Stage 1 will determine how Stage 2 will proceed (if Stage 2 is necessary) and provide information necessary to complete the risk characterization in Stage 3. The results from Stage 1 should clearly demonstrate that the site ecological endpoints or parameters are currently affected or could be affected by past chemical or radiological disposal. To evaluate this, BPV will consider the following five general result topics:

1. A statistical comparison of the site area and selected reference areas. The statistical analysis should show a difference in several of the field parameters discussed in Section A.4.1.3. However, results of the field studies will be presented to all concerned parties. Ambiguous or con licting findings could lead to Stage 2 studies, if recommended by BPV staff or required by DOE or the EPA.

2. Toxicity tests of chemicals and contaminated media. If such tests clearly show (based on statistical significance) that the site contamination poses a risk to test biota, Stage 2 studies will proceed. (In addition to the toxicity tests, the literature search will be used to evaluate chemical toxicity.) However, the fate studies conducted at the site must also show that the test conditions mimic projected conditions. For example, current chemical contamination could be attenuated or unavailable to the biota over time under current transport and fate conditions.

3. Residue analyses demonstrating bioaccumulation of biologically hazardous chemicals at the site. The fact that bioaccumulation is notad will not necessarily result in Stage 2 studies. The residue analysis must show that (1) the biouptake of the chemical or metal is producing or could produce deleterious results in biota; (2) bioaccumulation is widespread at the site; and (3) bioaccumulation poses a threat to human health, top predators, or threatened and endangered species.

4. Transport and fate studies of chemical contamination at the site. Because such studies have not been initiated, results will be factored into the requirements for Stage 2 studies. For example, if contaminated groundwater or sediment is found, projected to be widespread, or biologically available, Stage 2 studies will be initiated. The site ecological assessment team will work closely with others at the site to 
guarantee that the transport and fate studies are considered in the ecological assessment.

5. Discovery of protected species (e.g., federally threatened or endangered) during the inventories at the site. Such a discovery may require specific consideration of these populations in Stage 2. Any work on protected species will be coordinated with the FWS, DOE, and the EPA.

As part of the decision process at the end of Stage 1, results will be presented to DOE staff, other contractors, and the EPA to reach a consensus on the need for further investigations under Stage 2. Thus, the completion of Stage 1 could result in modifications to the present work plan. The BPV ecological assessment team will also communicate with colleagues at the BTAG and other contractors working at the site throughout Stage 1.

\section{A.4.2 Stage 2 Task Descriptions}

If the Stage 1 activities indicate some degree of ecological risk from on-site contaminants, the ecological assessment effort will be continued and expanded as Stage 2. The decision to initiate Stage 2 will depend upon the results from Stage 1, evaluation of the five Stage 1 topics (Section A.4.1.5), and professional judgment. Results from the preliminary toxicity tests and from the chemical characterization of the site will be used to refine toxicity tests, as necessary. For instance, specific chemicals identified from the disposal sites may be targeted, additional sites may be considered, or some sites may be eliminated from consideration. BPV anticipates that if Stage 2 is initiated, attention will focus on specific areas of contamination. Where feasible, toxicity tests conducted during Stage 2 would make use of species that inhabit the site. Furthermore, assessment and measurement endpoints and ecological models may require refinement. Results from Stage 2 will be translated into remediation goals and objectives in the ecological risk assessment report.

Selection and initiation of Stage 2 activities will depend in part on the evaluation of certain post-Stage 1 "decision points." For example, if statistical comparisons of field samples from the site and a reference location suggest significant differences (rejection of the relevant null hypothesis), appropriate Stage 2 activities will be initiated. These activities would include tissue analyses of biota common to both sites and further characterization of the sites' physical characteristics, with the Stage 2 objective being to determine if stress, mortality, or other measure of performance is a result of contamination or physical site disturbance.

As a further example, Microtox and preliminary bioassays (Stage 1) could provide evidence of toxicity or bioaccumulation. If this decision point is obtained, laboratory toxicity tests, histological studies, and establishment of microcosms would be established in Stage 2. Detection of residues in tissues (Stage 1) at a level considered to indicate the potential for toxic effects or bioaccumulation (decision point) would initiate further laboratory toxicity testing in Stage 2. 
Likewise, BPV will verify widespread, locally high, or temporally variable contamination in Stage 1 to justify additional field studies. Studies of caged populations of aquatic organisms will be included. For instance, caged studies could be performed at points where contaminated groundwater discharges into wetlands or streams. Finally, discovery of some sensitive ecological condition, species, or habitat during Stage 1 will be used to justify initiation of further Stage 2 characterization efforts, including refinement of receptor and endpoint selection.

Clearly, several Stage 1 activities could lead to the same Stage 2 efforts (e.g., toxicity tests and residue analyses) but at a finer level of resolution or at a different location at the site.

\section{A.4.3 Stage 3 Determination of Ecological Risk}

The EPA has produced guidance for the types of information that could be included in the risk assessment (EPA 1992). BPV will use these guidelines for the risk assessment. The following information is included in the EPA guidelines:

- Observed adverse effects in potentially exposed habitats compared to reference sites;

- Mortality and morbidity;

- Vegetation stress;

- Habitat degradation;

- Presence or absence of key species;

- Population assessment of key species;

- Community indices;

- Ecosystem functions, such as decomposition or nutrient recycling;

- Analysis of contaminant concentrations in relation to observed adverse effects;

- Analysis of bioaccumulation studies;

- Analysis of toxicity test results in relation to observed adverse effects;

- Comparison of estimated exposure point concentrations with criteria and standards;

- Comparison of estimated exposure point concentrations with toxicity data and/or toxicity values from literature, as appropriate; 
- Likely ecological risks associated with present and future land use scenarios;

- Ecologically applicable or relevant and appropriate requirements (ARARs);

- Ecological considerations in selecting remedial alternatives (including no action); and

- Uncertainty analysis.

For the decision maker, BPV will use the results from Stages 1 and 2 to provide information on (1) the need for remedial action at the Washbone site on the basis of ecological criteria and (2) (if remedial action is required) the type of remedial action that will protect the resources analyzed in the assessment. In the risk analysis, BPV will combine findings from field studies and toxicological analyses with the ecological models to develop a set of remedial action objectives and remediation goals. The risk assessment will also include an analysis of the impacts of any proposed remedial action on the ecological systems at the site. 


\section{A.5 REPORT PREPARATION}

At the conclusion of Stage 3, BPV will prepare a report that details the findings of the risk assessment and the projections of the system models. That report will document the areas sampled (terrestrial, wetland, stream), the biota sampled, the toxicity test results, the model assumptions and parameters, and all other necessary and relevant data contributing to the final ecological risk assessment for the site. The final report format will follow that proposed by the EPA (1992). 


\section{A.6 SAMPLING PROTOCOL}

\section{A.6.1 Sampling Strategy}

Much of the field sampling and data collection methods will follow those outlined in the ecological field sampling plan (BPV 1993a). Appendix B provides an annotated outline of this plan. The following sections reiterate the more salient points regarding field sampling and data collection and provide additional considerations for conditions that might be unique to the site.

\section{A.6.1.1 Wetland Sampling}

Analyses of the wetlands at the site and reference site will include interpretation of aerial photography and ground-truthing. These data can provide information on wetland vegetation community composition; wetland edge and open-water patterns (e.g., seasonal and long-term); occurrence and aerial coverage of terrestrial vegetation; occurrence and extent of sediment plumes; occurrence and intensity of algal blooms; and occurrence and number of muskrat dens, waterfowl nests, or other indicators of wildlife activity. All aerial photography will be placed in a digital database and manipulated with the BPV GIS.

BPV will conduct the jurisdictional wetland delineation (Federal Interagency Committee for Wetland Delineation 1989) and characterization (Cowardin et al. 1979) to provide a detailed mapping of the wetlands within the site and the selected reference sites. The wetland maps will be used to formulate sampling strategies and will be placed in the site GIS database. The maps will also be useful for GIS analyses of contaminant concentration contours, surface and groundwater flow patterns, areas of physical disturbance, and other factors. The GIS data will provide an initial analysis of wetland areas of potential ecological concern relative to contaminant migration.

BPV will conduct field sampling within the wetlands to determine community composition and abundance of vegetation, vertebrates, and macroinvertebrates. At a minimum, surveys will be conducted during two seasons (spring and late summer/early fall) to determine temporal conditions.

Data to be obtained from field sampling of wetland plant communities will include species composition and density, species dominance, percent vegetation cover, vegetation height, horizontal homogeneity or patchiness, percent occurrence of exotic and native species and obligate and facultative wetland species, and occurrence of species considered tolerant or intolerant of anthropogenic stressors.

Macrophyte surveys will coincide with the period of maximum growth (i.e., early summer). Methods used to inventory wetland vegetation include point-counts, quadrats, or other established plant sampling techniques. 
Vegetation surveys will consist primarily of visual observations. Voucher specimens and those specimens not readily identifiable in the field will be collected with standard plant sampling techniques. Collected specimens will be placed in individual plastic bags with labels identifying the collector, date, collection location, and taxonomic identification, if known. All collected voucher specimens will be processed with standard plant collection and preservation techniques and maintained in the site herbarium collection. Some specimens will be used for tissue analyses and for estimates of biomass/standing crop.

Sampling within wetlands will be conducted for fish and amphibians to provide estimates of species density, distributions, and diversity. Techniques for sampling fish will vary with habitat type and species expected (if any) but could include the use of electroshockers, seines, minnow traps, or lift or drop nets. Areas of importance to herpetofauna life cycles (e.g., breeding concentration areas) will be determined, and surveys will be conducted at least twice (spring and summer) during periods of greatest herpetofauna activity. Drift fences with pitfall traps or funnel traps will be used to collect herpetofauna. Timed searches (e.g., walking transects, overturning logs, searching slash piles, dip netting within standing water) will also be conducted to collect herpetofauna.

A variety of methods (e.g., sediment corers, dredges or grab samplers, sweep and dip nets, emergence traps) will be used to collect macroinvertebrates. Methods used will depend on the habitats and habits (e.g., sediment, open water, epiphytic) of the macroinvertebrates. Macroinvertebrate surveys will be designed to provide estimates of species density, distribution, and diversity.

A census survey (using timed searches) will be conducted in the wetland areas for waterfowl and shorebird use. Identification will be made by species; and the location, sex (for adults), and activity of each individual will be recorded. The summer census will attempt to determine if individuals use the on-site wetland for extended periods of time. Waterfowl and shorebirds using this habitat would have the potential for contaminant uptake from sediments and water. Depending upon the results of the survey, waterfowl game species may be collected for contaminant residue analyses.

Selected species of vertebrates and macroinvertebrates will be assessed for indications of contaminant effects, such as spinal deformities, fin erosion, and head capsule deformities.

Observational data on wetland condition can also provide potentially useful indications of wetland stress (EPA 1991b). Observational field data could include notation of debris accumulations, canopy dieback, presence of an unusual amount of fallen limbs, and damaged (including fire damaged) and uprooted trees.

\section{A.6.1.2 Stream Sampling}

The primary contaminant migration pathways to the streams bordering the site would be groundwater discharge and surface runoff. Bank erosion could result in 
contaminated soil entering the streams. Field sampling will be conducted at select locations at, upstream, and downstream of the site to determine community composition and abundance of fish and macroinvertebrates. Surveys will be conducted at least twice (spring and late summer/early fall) to determine seasonal and/or high and low discharge differences to the biota. Fish will be sampled primarily with seines and/or by electroshocking. Macroinvertebrates will be collected with quantitative sampling devices appropriate to the substrate conditions (e.g., Hess or Surber samplers for cobble substrates or corers or grab samplers for soft bottom substrates).

\section{A.6.1.3 Terrestrial Sampling}

Quantitative sampling of terrestrial flora will follow commonly accepted methods (e.g., Mueller-Dombois and Ellenberg 1974; Barbour et al. 1987). Sample plots will be larger for woody vegetation (e.g., $10 \times 10 \mathrm{~m})$ than for herbaceous vegetation $(1 \times 1 \mathrm{~m})$. Nested plots will be used where both woody and herbaceous vegetation occur. For woody vegetation, species and diameter at breast height will be recorded for each specimen in each woody vegetation plot. In addition, total canopy cover (percentage) will be recorded. For herbaceous samples, species, percent cover, and density will be recorded. These data will be used in estimates of population and community parameters.

Mammals will be sampled by EPA Class 1 techniques (EPA 1989c), including use of both live and snap traps. Live animals will be identified, tagged, weighted, sexed (if possible), and released. The same data will be recorded for dead animals. In addition, tissues or organs from dead animals will be analyzed for contaminant levels. Soil and litter invertebrates will be sampled with established collection methods to allow quantitative comparisons among sites. Those surveys will provide estimates of species density, distribution, and diversity. These data, together with the data from the vegetation sampling, will be input directly into the ecological risk assessment models.

Bird surveys will be conducted during spring and autumn migrations, breeding seasons, and the annual nationwide Christmas bird count. Surveys will be conducted using timed observational census methods. Binoculars, spotting scopes, and vocalizations will be used to document species occurrence. At each location, observations will be made for 15 minutes. Data to be recorded will include habitat type, weather, sex (for adults), behavior, species, and whether the observation was through visual or audio means. Night surveys will also be conducted. Taped recordings of suspected owls will be used to elicit responses. Field teams will maintain qualitative records of birds observed while conducting other activities during the field investigations. The data collected will be used to estimate species richness, density, and habitat use. Additionally, all active nests found during the investigation will be documented. Particular attention will focus on surveys for listed species or other species of special concern.

Quality control, quality assurance, and chain-of-custody procedures will be followed throughout all stages of biotic sample and data collection. Detailed QA/QC procedures will also be provided in any subcontractor's field sampling plan. 


\section{A.6.2 Physical Media Sampling}

The QAPP and the field sampling plan provide information on the technique, location, type, extent, and duration of the physical media sampling to be conducted at the site. The purpose of the field sampling plan is threefold: (1) to verify, refute, or modify the current conceptual model of the site contamination processes; (2) to determine the nature and extent of contamination at each contaminated area at the site; and (3) to identify pathways of contaminant location. The field sampling plan provides all details on sample numbers, data quality objectives, and sample locations. The QAPP contains requirements for sampling.

\section{A.6.3 Reference Area}

All sampling, data collection, and media handling procedures used at the site will be followed at the reference locations. To the extent possible, sampling will be in parallel. This parallel sampling will be a major factor in determining the number of field personnel required. 


\section{A.7 QUALITY ASSURANCE, QUALITY CONTROL, AND CHANN-OF-CUSTODY PROCEDURES}

Many of the QA/QC and chain-of-custody procedures will follow those outlined in the QAPP (BPV 1993b). Appendix C provides an annotated outline of the QAPP. The following sections reiterate the more salient points regarding the $Q A / Q C$ and chain-of-custody procedures.

\section{A.7.1 Quality Assurance Measures}

The EPA requires all of its laboratories, program offices, and regional offices to participate in a QA program. This applies to all environmental sampling, monitoring, and measurement efforts supported by the EPA or mandated through contracts, regulations, and/or formal agreements. The EPA recommends that a formal QA plan be developed for all data-generating activities associated with ecological assessments at hazardous waste sites (EPA 1989a).

The QA measures identified in this work plan include all aspects of laboratory and field procedures that affect the accuracy and precision of the data, including the collection and handling of soil, sediment, and biological samples; the source and condition of all test organisms; the condition of all sampling and test equipment; instrument calibration; sample replicates and controls; record keeping; and data analysis and evaluation. The QA procedures include the maintenance of chain-of-custody, collection of QA samples, and the documentation of collection and analytical procedures.

Additional, more detailed and separate QA procedures will be developed for all subcontractor activities (laboratory and field), and these procedures will be submitted and reviewed before any portion of this ecological risk assessment plan is initiated. The appropriate data QA/QC measures will be followed, as outlined in Appendix C.

\section{A.7.2 Data Management}

Data collected as part of the ecological risk component of the site focused RIFS will be stored in the Installation Restoration Data Management System or in the Biological/Ecological Database Management System being developed to support the site bioassessment work. The data management system for the ecological risk assessment is described by BPV (1993b). 


\section{A.8 TECHINICAL SUPPORT AND FACILITIES}

Subcontractors will be employed to perform field sampling and laboratory analyses. These subcontractors will be required to prepare an approved work plan (including QA/QC procedures). Additional support, in the form of physical space at the site for BPV investigators and other personnel and necessary capital, will be required for the efficient completion of this ecological risk assessment. 


\section{A.9 REFERENCES ${ }^{9}$}

ASTM, 1992, 1992 Annual Book of ASTM Standards, Section 11 Water and Environmental Technology, American Society for Testing and Materials, Philadelphia, Penn.

ASTM, 1990, Standard Guide for Conducting 10-Day Static Sediment Toxicity Tests with Marine and Estuarine Amphipods, ASTM Standard E1367-90, Philadelphia, Penn.

Barbour, M.G., et al., 1987, Terrestrial Plant Ecology (2nd ed.), Benjamin/Cummings, Menlo Park, Calif.

Bartell, S.M., R.H. Gardner, and R.V. O'Neill, 1992, Ecological Risk Estimation, Lewis Publishers, Boca Raton, Fla.

[BPV (BP\&V Associates), 1992, Remedial Investigation Sampling and Analysis Plan for the Washbone Site, Burke County, Georgia, Volume 1: Field Sampling Plan, prepared for U.S. Department of Energy, Washington, D.C. by BP\&V, Associates, Wood Grove, Ill., Dec.]

[BPV, 1993a, Remedial Investigation Sampling and Analysis Plan for the Washbone Site, Burke County, Georgia, Volume 2: Ecological Sampling Plan, prepared for U.S. Department of Energy, Washington, D.C., by BP\&V, Associates, Wood Grove, Ill., Jan.]

[BPV, 1993b, Remedial Investigation Sampling and Analysis Plan for the Washbone Site, Burke County, Georgia, Volume 3: Quality Assurance Project Plan, prepared for U.S. Department of Energy, Washington, D.C., by BP\&V, Associates, Wood Grove, Ill., Feb.]

Burton, G.A., Jr., 1991, Assessing the Toxicity of Freshwater Sediments, Environmental Toxicology and Chemistry 10:1585-1627.

Callahan, C.A., et al., 1991, On-Site Methods for Assessing Chemical Impact on the Soil Environment Using Earthworms: A Case Study at the Baird and McGuire Superfund Site, Holbrook, Massachusetts, Environmental Toxicology and Chemistry 10:817-926.

Carlson, C.L., et al., 1991, Effects of Selected Trace Metals on Germinating Seeds of Six Plant Species, Water, Air, and Soil Pollution 59:231-240.

Cowardin, L.M., et al., 1979, Classification of Wetlands and Deepwater Habitats of the United States, FWS/OBS-79/31, Biological Services Program, U.S. Fish and Wildlife Service, Washington, D.C.

Cowgill, U.M., et al., 1991, The Sensitivity of Lemna gibba G-3 and Four Clones of Lemna minor to Eight Common Chemicals Using a 7-day Test, Research Journal Water Pollution Control Federation 63:991-998.

9 All references are citations of actual publications, except those bracketed. Those are fictitious citations created for the work plan example. 
[DOE (U.S. Department of Energy), 1988, Baseline Assessment for the Washbone Site, Burke County, Georgia, DOE/OR/56789-088, prepared by U.S. Department of Energy, Washbone Site Remedial Action Project, Washington, D.C., Nov.]

[DOE, 1990, Environmental Monitoring for the Washbone Site for Calendar Year 1989, DOE/OR/98765-090, prepared by U.S. Department of Energy, Washbone Site Remedial Action Project, Washington, D.C., March.]

EPA (U.S. Environmental Protection Agency), 1989a, Risk Assessment Guidance for Superfund, Environmental Evaluation Manual, Interim Final, EPA/540/1-89/001, Office of Emergency and Remedial Response, Washington, D.C.

EPA, 1989b, Ecological Risk Assessment Methods: A Review and Evaluation of Past Practices in the Superfund and RCRA (Resource Conservation and Recovery Act) Programs, EPA-23003-89-044, Office of Policy Analysis, Washington, D.C.

EPA, 1989c, Summary of Ecological Risks, Assessment Methods, and Risk Management Decisions in Superfund and RCRA, EPA-230-03-89-046, Office of Policy Analysis, Washington, D.C.

EPA, 1989d, Ecological Assessment of Hazardous Waste Sites: A Field and Laboratory Reference, EPA/600/3-89/013, U.S. Environmental Protection Agency, Environmental Research Laboratory, Corvallis, Ore., March.

EPA, 1991a, Summary Report on Issues in Ecological Risk Assessment, EPA/625/3-91/018, Office of Health and Environmental Assessment, Washington, D.C.

EPA, 1991b, Environmental Monitoring and Assessment Program Research Plan for Monitoring Wetland Ecosystems, EPA/600/5-91/010, U.S. Environmental Protection Agency, Environmental Research Laboratory, Corvallis, Ore., Feb.

EPA, 1992, ECO Update: Developing a Work Scope for Ecological Assessments, EPA 9345.0051, Washington, D.C., May.

Federal Interagency Committee for Wetland Delineation, 1989, Federal Manual for Identifying and Delineating Jurisdictional Wetlands, U.S. Army Corps of Engineers, U.S. Environmental Protection Agency, U.S. Fish and Wildlife Service, and Soil Conservation Service, Washington, D.C.

Fletcher, J.S., 1990, "Use of Algae Versus Vascular Plants to Test for Chemical Toxicity," in W. Wang, J.W. Gorsuch, and W.R. Lower (eds.), Plants for Toxicity Assessment, ASTM STP 1091, American Society for Testing and Materials, Philadelphia, Penn., pp. 33-39.

Giesy, J.P., and R.A. Hoke, 1989, Freshwater Sediment Toxicity Bioassessment: Rationale for Species Selection and Test Design, Journal of Great Lakes Research 15:539-569. 
Gorsuch, J.W., ot al., 1991, Plants for Toxicity Assessment, (2nd vol.), American Society for Testing and Materials, Philadelphia, Penn.

Harper, J.L., 1977, Population Biology of Plants, Academic Press, London, England.

Hunsaker, C.T., et al., 1989, Regional Ecological Risk Assessment: Theory and Demonstration, ORNL/TM-11128, Oak Ridge National Laboratory, Oak Ridge, Tenn.

Ingersoll, C.G., 1991, Sediment Toxicity and Bioaccumulation Testing, Standard News 19(4):28-33.

Karnak, R.E., and J.L. Hamelink, 1982, A Standardized Method for Determining the Acute Toxicity of Chemicals to Earthworms, Ecotoxicology and Environmental Safety 6:216-222.

Kimball, K.D., and S.A. Levin, 1985, Limitations of Laboratory Bioassays: The Need for Ecosystem-Level Testing, BioScience 35:165-171.

Levin, S.A., and K.D. Kimball, 1984, New Perspectives in Ecotoxicology, Environmental Management 8:375-442.

Levin, S.A., M.A. Harwell, J.R. Kelly, and K.D. Kimball (eds.), 1989, Ecotoxicology: Problems and Approaches, Springer-Verlag, New York.

Menzie, C.A., et al., 1992, Assessment of Methods for Estimating Ecological Risk in the Terrestrial Component: A case Study at the Baird and McGuire Superfund Site in Holbrook, Massachusetts, Environmental Toxicology and Chemistry 11:245-260.

Mueller-Dombois, D., and H. Ellenberg, 1974, Aims and Methods of Vegetation Ecology, Wiley, New York.

NAS (National Academy of Sciences), 1975, Principles for Evaluating Chemicals in the Environment, Washington, D.C.

Orvos, D.R., and J. Cairns, Jr., 1991, Developing a Risk Assessment Strategy for the Chesapeake Bay, Hydrobiolgia 215:189-203.

Outridge, P.M., and B.N. Noller, 1991, Accumulation of Toxic Trace Elements by Freshwater Vascular Plants, Reviews of Environmental Contamination and Toxicology 121:1-63.

Rowley, M.H., et al., 1983, Use of Small Mammals (voles) to Assess a Hazardous Waste Site at Love Canal, Niagara Falls, New York, Archives of Environmental Contamination and Toxicology 12:383-397.

Severinghaus, W.D., 1981, Guild Theory Development as a Mechanism for Assessing Environmental Impact, Environmental Management 5:187-190. 
Stevens, D.L., Jr., 1988, Field Sampling Design, in W. Warren-Hicks (ed.), Ecological Assessments of Hazardous Waste Sites: A Field and Laboratory Reference Document, EPA/600/3-89/013, U.S. Environmental Protection Agency, Corvallis, Ore., pp. 4-1 - 4-13.

Suter, G.W., II, et al., 1987, Treatment of Risk in Envirrnmental Impact Assessment, Environmental Management 11:295-303.

Wang, W., 1986a, Comparative Toxicology of Phenolic Compounds Using Root Elongation Method, Environmental Toxicology and Chemistry 5:891-896.

Wang, W., 1986b, Toxicity Tests of Aquatic Pollutants by Using Common Duckweed, Environmental Pollution (Series B) 11:1-14.

Wang, W., et al., 1990, Plants for Toxicity Assessment, American Society of Testing and Materials, Philadelphia, Penn.

Whittaker, R.H., 1975, Communities and Ecosystems (2nd ed.), Macmillan, New York. 


\section{APPENDIX B:}

ECOLOGICAL FIELD SAMPLING PLAN ANNOTATED OUTLINE 


\section{APPENDIX B: \\ ECOLOGICAL FIELD SAMPLING PLAN ANNOTATED OUTLINE}

\section{B.1 INTRODUCTION}

\section{B.1.1 Background}

This section should provide a brief history of the use, description, and location of the site. Included should be a brief discussion of the contaminated areas of concern at the site.

\section{B.1.2 Objective and Scope of the Field Sampling Plan}

This section should discuss the objectives of the ecological field sampling plan (e.g., to verify or change the conceptual site model; determine the nature and extent of contamination; and determine the presence, absence, or significance of environmental receptors). The purpose of this report should also be discussed (e.g., to provide guidance for all ecological fieldwork to be conducted in association with the remedial investigation/feasibility study [RI/FS] investigation).

\section{B.1.3 Report Organization}

This section should briefly discuss what each chapter of the field sampling plan document addresses.

\section{B.2 SITE SETTING AND BACKGROUND}

\section{B.2.1 Site Background}

This section should discuss the historic and current uses and status of the project site. This could include an associated table that describes each contaminated area of concern at the site, the period of use of these areas, and the activities conducted at each area. Subsections can be written to provide more detail on each distinct contaminated area of concern at the site. 


\section{B.2.2 Environmental Setting}

\section{B.2.2.1 Surface Features}

This section should briefly describe the slope, surface relief, water bodies, wetlands, tree stands, and other surface features of the site.

\section{B.2.2.2 Climate}

This section should briefly describe the climate of the area, emphasizing precipitation characteristics.

\section{B.2.2.3 Geology and Soils}

The stratigraphy and soils of the site should be briefly discussed.

\section{B.2.2.4 Surface Water}

Surface waters and wetlands that occur on or adjacent to the site should be discussed.

\section{B.2.2.5 Groundwater}

The major hydrologic units identified beneath the site should be briefly discussed. Emphasis should be placed on the surficial aquifer, and a figure could be included that shows groundwater flow direction and other pertinent information.

\section{B.2.2.6 Ecology}

This section should briefly describe the habitat types found on and near the site. An abbreviated listing of the common species of the site area can also be provided. Federally listed species or other unique species or habitats that occur on or near the site should also be mentioned.

\section{B.2.3 Previous Investigations}

This section should briefly discuss any investigations that have been conducted at the site. Information to be provided should include justification of why the studies were conducted, site study locations, and conclusions from the results of previous studies. The following subsection titles are examples of the categories of studies that may have been conducted at a site. 


\section{B.2.3.1 Hydrogeological Investigations}

\section{B.2.3.2 Surface Water Investigations}

\section{B.2.3.3 Ecological Investigations}

\section{B.2.4 Concurrent Investigations}

This section should summarize other investigations that are being conducted on or near the site. These summaries should include the basic objective(s) of each study and how they may complement the proposed ecological investigation.

\section{B.3 ECOLOGICAL CONTAMINANTS OF CONCERN}

This section should briefly describe the contaminants of concern to ecological resources at the site. The basis for the choice of the contaminants should also be summarized. A table summarizing the contaminants of potential concern should be included.

\section{B.4 CONTAMINANT TRANSPORT AND FATE ANALYSIS}

The goals (i.e., data quality objectives) of the ecological field sampling plan should be summarized.

\section{B.4.1 Data Gaps}

Data gaps that the sampling plan would address should be discussed.

\section{B.4.2 Conceptual Site Model}

This section should describe the conceptual site model, which links the sources and mechanisms to ecological receptors through various pathways and exposure routes. A figure of the conceptual site model should also be included.

\section{B.4.3 Transport Analysis}

The analysis of contaminant transport and fate describes the extent and magnitude of environmental contamination. It also includes determining the bioavailability of contaminants, the specific media with which the contaminants are associated, the physicochemical characteristics of the medium, and the chemical form of the contaminants. 


\section{B.4.3.1 Terrestrial Transport}

This section should briefly discuss contaminant transport mechanisms in the terrestrial ecosystems: (1) transfer of contaminants from surrounding media (primarily soils) to terrestrial biota (including food chain transfer), (2) effect of contaminants on terrestrial biota (including special concern species), and (3) contaminant residuals in terrestrial biota (including tissues of species consumed by humans).

\section{B.4.3.2 Wetland Transport}

This section should briefly discuss contaminant transport mechanisms in the wetland ecosystems: (1) transfer of contaminants from surrounding media (water and sediments) to wetland biota (including food chain transfer), (2) effect of surface water and sediment contaminants on wetland biota (including special concern species), and (3) contaminant residuals in wetland biota (including tissues of species consumed by humans).

\section{B.4.3.3 Aquatic Transport}

This section should briefly discuss contaminant transport mechanisms in the aquatic ecosystems: (1) transfer of contaminants from surrounding media (water and sediments) to aquatic biota (including food chain transfer), (2) effect of surface water and sediment contaminants on aquatic biota (including special concern species), and (3) contaminant residuals in aquatic biota (including tissues of species consumed by humans).

\section{B.5 SAMPLING PROGRAM}

For the most part, the equipment and methods used to collect, handle, store, analyze, and document environmental media are provided in the relevant standard operating procedures and are described in the text or the appendices to the quality assurance project plan (QAPP).

\section{B.5.1 Site Selection}

\section{B.5.1.1 Terrestrial Systems}

This section should describe the areas that would be sampled for terrestrial surveys, biouptake sampling, and in situ toxicity tests. Reference (background) site(s) should be included in this description. A brief discussion of the rationale for selection of these sites should also be included. 


\section{B.5.1.2 Wetland Systems}

This section should describe the areas that would be sampled for wetland surveys and for biouptake sampling, and in situ toxicity tests. Reference (background) site(s) should be included in this description. A brief discussion of the rationale for selection of these sites should also be included.

\section{B.5.1.3 Aquatic Systems}

This section should describe the areas that would be sampled for aquatic surveys, biouptake sampling, and in situ toxicity tests. Reference (background) site(s) should be included in this description. A brief discussion of the rationale for selection of these sites should also be included.

\section{B.5.2 Sample Collection and Survey Methods}

\section{B.5.2.1 Terrestrial Sampling}

This section would discuss the purpose and methods for terrestrial sampling The following subsections are examples for several biotic assemblages. Similar discussions would be required if other assemblages were sampled (e.g., large mammals and reptiles).

B.5.2.1.1 Vegetation. The first portion of this section would discuss the purpose for sampling vegetation. Following that would be a description of the quantitative and qualitative sample collection and survey methods that would be used to characterize the vegetation (e.g., transect or quadrat design, sampling periods (seasons), and data to be recorded). Where pertinent, discussions would also be included pertaining to methodologies to be used in collection of samples for residual (contaminant) analyses and for conducting in situ toxicity tests.

B.5.2.1.2 Small Mammals. The first portion of this section would discuss the purpose for sampling small mammals. Following that would be a description of the quantitative and qualitative sample collection and survey methods that would be used to capture small mammals (e.g., type of traps, transect or grid design, sampling periods (seasons and trapping days per season), and data to be recorded for collected species). A brief discussion would also be included pertaining to individuals who would be analyzed for contaminant concentrations.

B.5.2.1.3 Birds. The first portion of this section would discuss the purpose for sampling birds. Following that would be a description of the methods that would be used to birds (e.g., transect methods, equipment, time of day and length of surveys, and data to be 
recorded). A brief discussion would also be included pertaining to individuals who would be analyzed for contaminant concentrations.

\section{B.5.2.2 Wetland Sampling}

This section would discuss the purpose and methods for wetland sampling. Subsections similar to those for terrestrial sampling (Section B.5.2.1) would be required (e.g., for wetland vegetation, macroinvertebrates, fish, amphibians and reptiles, birds, and mammals). In addition, discussion should be provided on how wetland delineations would be conducted.

\section{B.5.2.3 Aquatic Sampling}

This section would discuss the purpose and methods for aquatic sampling. Subsections similar to those for terrestrial sampling (Section B.5.2.1) would be required (e.g., for aquatic vegetation, zooplankton, macroinvertebrates, fish, amphibians, and birds).

\section{B.6 QUALITY ASSURANCE}

This section should briefly summarize quality assurance and chain-of-custody standards applicable to the ecological field sampling plan. Brief descriptions would be provided for sample identification, taxonomic identification, analytical requirements, quality assurance samples, sample shipment and chain-of-custody, and data administration. (The QAPP should be referenced, as appropriate.)

\section{B.7 DATA REPORTING}

This section should describe how the data would be analyzed and reported. Included should be a presentation of formulas and methods that would be used to present population and community descriptors such as relative abundance, density, diversity, species richness, biotic indices, and ecological tolerance and sensitivity indicators; and represent results from residual (contaminant) analyses and in situ toxicity tests. Included should be a discussion of how information from the site would be compared to similar information collected from the reference (background) site(s). This would include various statistical tests (e.g., T-tests, correlations, Mann-Whitney U-tests).

\section{B.8 REFERENCES}

This section should list complete citations for all references called out in the text. 


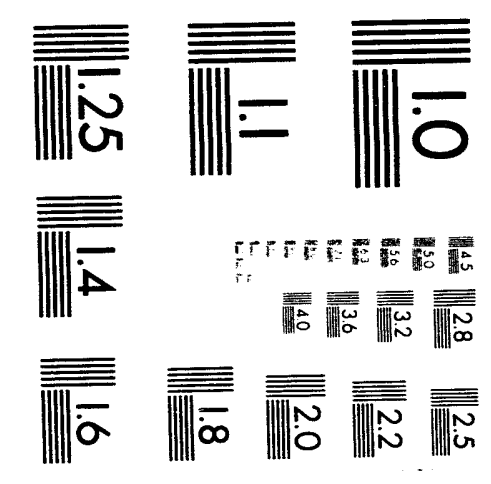



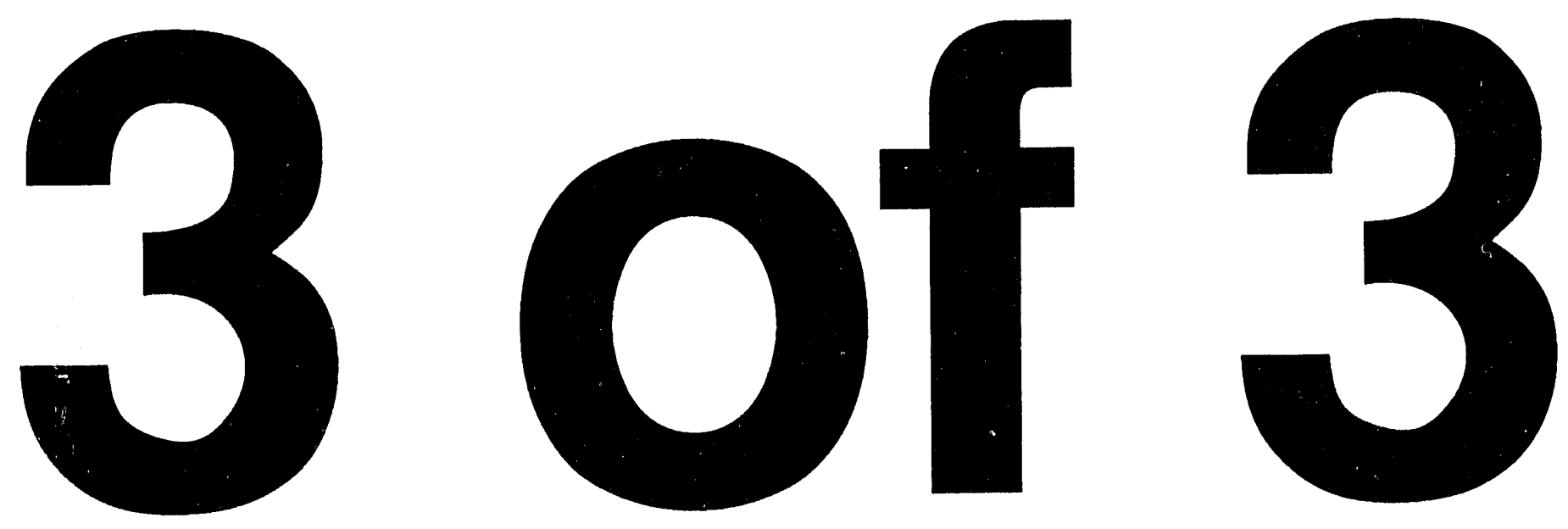


\section{APPENDIX C:}

\section{ECOLOGICAL QUALITY ASSURANCE PROJECT PLAN ANNOTATED OUTLINE}




\section{APPENDIX C: \\ ECOLOGICAL QUALITY ASSURANCE PROJECT PLAN ANNOTATED OUTLINE}

\section{C.1 INTRODUCTION}

Briefly explain that the quality assurance project plan (QAPP) delineates the purpose, policies, standard operating procedures (SOPs), and organization of the quality assurance (QA) program, which is used to establish the integrity of the site project activities. Briefly state what is addressed in the remaining chapters (e.g., one sentence per section).

\section{C.1.1 Purpose of the Quality Assurance Project Plan}

The overall QA objective is to develop and implement procedures for sample and data collection, sample shipment, and reporting that will allow QA reviewers to determine, with reasonable certainty, whether the abiotic and biotic sampling and the field and laboratory data collected during the remedial investigations at the site meet the criteria and endpoints in the data quality objectives (DQOs). The QA plan covers all environmentally related measurements and includes the measurement of chemical, physical, and biological parameters in the environment to support the site ecological risk assessment.

\section{C.1.2 Scope of the Quality Assurance Project Plan}

The QAPP establishes responsibilities and authorities for data quality and defines procedures to ensure that field and laboratory activities result in quality data. Inherent in the QA program is the implementation of quality control (QC) measures. These measures ensure that quality-related events have been monitored and that data gathered in support of the project are accurate, precise, representative of the sample matrix, and complete.

\section{C.2 PROJECT DESCRIPTION}

\section{C.2.1 Project Scope}

A brief description should be provided on how the ecological risk assessment (ERA) process is being developed as part of the remedial investigation/feasibility study (RI/FS) activities at the site. A short review of site contaminants should be provided. Also, a brief rationale should be provided as to why the site requires an RIFS investigation. 


\section{C.2.2 Project Objective}

Discuss how an ERA for the site will be conducted, using (1) bioassays, (2) whole organism and tissue contaminant analyses (i.e., residue analyses), and (3) community analyses (ecological surveys). A discussion of guidelines developed to ensure that bioassessment techniques chosen for the program are adequate to address the contaminant/environment interactions at the site should also be included.

\section{C.2.3 Site Background}

Provide a brief history of the site, including operations that resulted in site contamination. Brief statements on weather, geology, ecology, etc., can also be included in this section.

\section{C.2.4 Field Operations}

Field activities to be performed in conjunction with the project should be included in this section. Activities described should include the various physical and biotic characterizations surveys, residue analyses, bioassays, etc., that would be conducted in the field or from field samples. A list of tasks to be performed and any important milestones can be included in a time-line graph format.

\section{C.3 PROJECT AND QAQC ORGANIZATION AND RESPONSIBILITY}

Implementation of the QAPP requires that the project staff maintain an awareness of contractual procedures and goals. It is the contractor's responsibility to develop a QA program to ensure that all information produced by employees and subcontractors is valid and of known quality. QA program requirements cover all activities that generate environmental measurement data.

\section{C.3.1 Responsibilities}

This section should describe responsibilities of the project leader and QA manager. The DOE project leader for the site ERA is typically responsible for (1) oveiseeing and monitoring the performance of all RI/FS participants, (2) interacting with regulatory agencies, (3) being a liaison among DOE and the RI/FS contractors, (4) requiring effective implementation of the QA program, and (5) requiring corrective actions, when necessary.

\section{C.3.1.1 Project Quality Assurance and Quality Control}

The project leader and QA manager are responsible for implementing the QA program. Responsibilities include (1) initiating QA activities; (2) ensuring documentation and 
maintenance of all records, logs, SOPs, ancl analytical results; (3) conducting periodic performance audits; (4) preparing periodic quality reports; and (5) ensuring that corrective actions are taken as necessary.

\section{C.3.1.2 Field Activities}

The QA manager must ensure that all field team members possess appropriate qualifications and training before collection of samples.

\section{C.3.2 Project Organization}

Included should be a figure showing the line of authority and project organization for the ERA as well as a table that provides the names, titles, addresses, and phone numbers of the principal players involved in the ERA and QA programs.

\section{C.4 QUALITY ASSURANCE AND DATA QUALITY OBJECTIVES}

\section{C.4.1 Quality Assurance}

The purpose of this section is to define QA goals for accuracy, precision, representativeness, completeness, and comparability.

\section{C.4.1.1 Accuracy}

For samples collected for chemical analysis, accuracy will be checked quantitatively through the use of spikes and blanks controlled by the laboratory certified by the Contract Laboratory Program (CLP). Accuracy of field measurements will be qualitatively controlled through the use of SOPs developed to standardize the collection of measurements and samples. (A definition of accuracy and methods to calculate accuracy should be included in this section.)

\section{C.4.1.2 Precision}

For samples collected for chemical analysis, sampling precision will be checked by replicate analyses performed on each sample matrix. (A definition of precision and methods to calculate precision should be included in this section.) 


\section{C.4.1.3 Representativeness}

The definition of representativeness (the degree to which measured results accurately reflect the medium being sampled) and protocols to ensure representativeness should be included in this section.

\section{C.4.1.4 Completeness}

A discussion of completeness (a measure of the amount of information that must be collected to allow a successful achievement of objectives) should be included.

\section{C.4.1.5 Comparability}

Comparability (the confidence with which one data set can be compared with another) should be defined, and methods to control it should be described.

\section{C.4.2 Data Quality Objectives}

DQOs are qualitative and quantitative statements that outline the decision-making process and specify the data required to support the ERA. Tables can be included that summarize the DQOs for bioassays, residue and community analyses, biotic and abiotic sampling, and other sampling or analyses conducted to support the ERA. The following is an example of DQOs for seed germination and root elongation bioassays: (1) objective rapid screening of phytotoxicity of soils; (2) test/target media - soil or sediment; (3) test/target group - plants; (4) test/target species - lettuce, radish, Spartina, Juncus, or similar species; (5) bioassay endpoint - seed germination (at 5 days) and/or root elongation (at 10 days); (6) bioassay method reference - U.S. Environmental Protection Agency (EPA 1989) "Protocols for Short Term Toxicity Screening of Hazardous Waste Sites," EPA $600 / 388 / 029$; (7) quality control - control group survival must be $\geq 90 \%$, all reference assays must fall within control limits, three replicates per test concentration; and (8) data level EPA Level II. Similar DQOs would be established for all other bioassays conducted for the ERA.

The following is an example of DQOs for fish residue analysis: (1) objective evaluation of bioaccumulation of contaminants in fish; (2) data use - toxicity and exposure assessments; (3) test/target media - whole organism and tissues; (4) test/target group fish; (5) test/target species - abundant species from several trophic groups, benthic feeder, and/or game species; (6) measurement endpoint - chemical residue; (7) chemical and environmental data - various contaminants of concern; (8) sampling method - whole body and fillet; (9) analytical methods - e.g., atomic absorption, gas chromatography; (10) typical analytical or statistical detection limit - typically $5 \mathrm{ppb}$ to $5 \mathrm{ppm}$; (11) quality control samples - duplicates, method blanks, matrix spikes, reference materials of known concentrations; and (12) data level - EPA Level IV. Similar DQOs would be established for all other residue and community analyses. 


\section{C.4.3 Controlling and Assessing the Quality of Data}

This section should include a brief description of the sampling design to ensure that statistically valid data are collected.

\section{C.4.3.1 Sampling Design}

Appropriate designs may include simple random sampling, stratified random sampling, two-stage sampling, and cluster sampling; and replicate sample collections will be conducted to allow for a statistically designed sampling plan.

\section{C.4.3.2 Blank Contamination Assessment}

A blank contamination assessment (i.e., field blanks, trip blanks, and laboratory blanks) should be performed to determine the impact of contaminant contributions originating from nonpoint sources.

\section{C.5 SAMPLING}

\section{C.5.1 Sample Labeling}

Each sample will be given a permanently affixed label including sample number, sample date, preservative, analyte(s), sampler's initial, and installation/sample location name.

\section{C.5.2 Containers}

All sample containers will be cleaned before use in accordance with EPA protocols. Tables should be included that cover sample preservation, bottle requirements, and holding times for aqueous, solid, physical, and biotic samples.

\section{C.5.3 Sample Preservation}

Preservatives will be added to appropriate samples at the time of collection. The required preservatives should be delineated in the tables first called out in Section C.5.2. In addition to preservatives, samples for chemical analysis should be transported in temperature-controlled coolers. Information should be provided that describes the procedural steps for chemical sample preservation. 


\section{C.5.4 Sample Collection}

Detailed procedures for the collection of samples are provided in SOPs and references cited later in the varicus appendices of the QAPP. Therefore, these procedures do not need to be detailed in the QAPP. Collection of all samples will follow EPA and DOE protocols. This section discusses the collection of $\mathrm{QC}$ samples and field dissection of biota.

\section{C.5.4.1 Quality Control Samples Collected in the Field}

Quality control samples will include duplicates, rinse blanks/equipment blanks, and trip blanks.

\section{C.5.4.2 Field Dissection of Biological Tissues}

The methods to be used to obtain tissue/organ samples, while preventing sample contamination, should be detailed in this section.

\section{C.5.5 Sample Custody}

Evidence of sample custody needs to be traceable from the time clean sample bottles leave the laboratory to the time that filled sample bottles are brought back to the laboratory for analysis. The following subsections include specific QA plan requirements regarding sample custody labeling and record keeping.

\section{C.5.5.1 Custody Seals}

Custody seals will be signed, dated, and affixed to shipment containers transporting sample bottles from the laboratory. Similar seals also will be required across cooler openings to ensure integrity of samples during shipment from the field to the laboratory.

\section{C.5.5.2 Chain of Custody}

Chain-of-custody forms will accompany sample containers and collected samples during the entire sampling process. A description of where each copy of the form goes should be included.

\section{C.5.5.3 Sample Receipt}

The chain-of-custody process for laboratory receipt of samples should be delineated in this section. This would include logging in samples, checking custody seals and the temperature of sample coolers, assigning lot numbers, and entering information into the computer tracking system. 


\section{C.5.5.4 Laboratory Receipt}

The sequence of events once the samples are transmitted to the laboratory should be delineated in this section. These would include sample log-in and storage (including logging of refrigerator/storage temperatures).

\section{C.5.6 Field Equipment Calibration}

Proper calibration and documentation (recording of usage, maintenance, calibration, and repair) of field equipment is required to ensure that field equipment is functioning properly.

\section{C.5.6.1 Frequency of Field Calibration}

Schedules for calibration of various field instrumentation and equipment should be addressed in this section.

\section{C.5.6.2 Calibration Standards}

Appropriate standards that equipment will be calibrated with should be addressed in this section.

\section{C.6 SAMPLE ANALYSIS}

\section{C.6.1 Sample Management}

This section should include the name of the supplier (e.g., Contract Laboratory) for the following: clean sample containers, shipping containers, sample preservatives, trip blanks, sample labels, custody seals, and so forth. Sample container cleaning and handling of preservatives should also be addressed in this section.

\section{C.6.2 Sample Holding Times}

A column can be added to the tables called out in Section C.5.2 that provides the allowable holding times for the various samples collected for analyses. 


\section{C.6.3 Laboratory Analytical Procedures}

\section{C.6.3.1 Methods for Analysis of Abiotic Samples}

Methods to be used to analyze abiotic samples should be detailed. In addition to text descriptions, tables should also be included to summarize methods and quantitation limits for inorganic compounds, volatile organic compounds, semivolatile organic compounds, radionuclides, physical parameters (e.g., water quality analyses and classification of soils), and so forth.

\section{C.6.3.2 Methods for Assessment of Biotic Samples}

This section would have text and tables similar to those in Section C.6.3.1. However, there should also be a discussion of how samples would be initially prepared in the laburatory for analyses.

\section{C.6.4 Calibration of Laboratory Instrumentation}

Before sample analysis, chemical calibration for each target analyte must be performed to ensure that analytical instrumentation is functioning within established sensitivity ranges. These would entail daily and initial calibrations, as required.

\section{C.6.5 Solution Validation}

All calibration solutions and standards to be used will be prepared and maintained under the normal laboratory standards tracking system. This system must include preparation, checking, documentation, storage, and disposal of standards according to specified procedures and schedules appropriate for each analyte of interest.

\section{C.6.6 Reference Materials}

Reference standards are required to calibrate instruments, spike analytical surrogates or standards, and prepare QC samples. This section should include the source of reference materials and storage requirements for them.

\section{C.6.7 Data Validation, Reduction, and Reporting}

\section{C.6.7.1 Collection}

This section should describe how data are initially collected, converted to standard reporting units, and recorded in standard formats by the project analysts. 


\section{C.6.7.2 Validation}

This section should describe how all generated data will be assessed for accuracy, precision, and completeness. This should include mention of the various $\mathrm{QC}$ checks and system audits to be performed during the entire data collection process.

\section{C.6.7.3 Reduction}

This section should describe data reduction methods that would be used and how the reliability and accuracy of the data would be maintained.

\section{C.6.7.4 Reporting}

This section should describe the system(s) within which the validated data (and qualifiers, as appropriate) will be reported.

\section{C.7 SYSTEM CONTROLS}

\section{C.7.1 Document Control}

A document control program is established to ensure that all documents issued or generated will be accounted for at the end of the project. A brief description of this program and a listing of the documents projected to be used or prepared during the project should be provided. The latter could include maps and photographs, chain-of-custody records, logbooks, correspondence, reports, etc.

\section{C.7.2 Internal Laboratory Quality Control Samples}

QC samples are prepared and analyzed internally to provide quantitative evidence supporting the performance of the analytical system. In addition to defining QC samples, this section should discuss who will prepare the QC samples, the types of QC samples (i.e., blanks, laboratory control samples and/or spiked blanks, and duplicates), and the frequency of analysis of QC samples (e.g., one per lot of 20 or less samples).

\section{C.7.3 Control Charts}

Control charts are used to monitor the trends and variations in the accuracy and precision of analytical analyses. In addition to defining control charts, this section should list information that would be contained in the charts. 


\section{C.7.4 Out-of-Control Conditions}

Out-of-control situations arise from failure to adhere to SOPs, policies, and protocols delineated in the QA program. A listing of out-of-control conditions that could occur during the project should be included (e.g., improper sampling techniques, improper calibration, and improper sample storage). Mention should also be made that corrective actions would be warranted (refer to Section C.11, which addresses corrective actions).

\section{C.8 PREVENTIVE MAINTENANCE}

The objectives of the preventive maintenance plan for periodic instrumentation checks should be addressed. A calibration and maintenance schedule for field and laboratory equipment should be provided. Reference can be made to applicable publications and other QA programs that address the calibration and maintenance of equipment.

\section{C.9 RECORD KEEPING}

This section involves information on logbooks that would be kept for record-keeping purposes for both field and laboratory activities.

\section{C.9.1 Sampling}

This section should provide a listing of the information that would be required in the logbook for each sample collected in the field for analysis.

\section{C.9.2 Laboratory Records}

\section{C.9.2.1 Laboratory Logging}

This section should list the information to be written into the logbook once samples are received by the laboratory. These would include field sample number, date of receipt, sample condition, analysis required, and so forth.

\section{C.9.2.2 Sample Identification Numbers}

This section should describe how sample identification numbers would be assigned to each aliquot of a sample (e.g., based on the number of samples that can be analyzed within a 24-hour period and the order in which these samples will be analyzed). 


\section{C.9.2.3 Analytical Records}

C.9.2.3.1 Reference Materials. This section should list the information that will be logged in for all reference materials used for analytical purposes.

C.9.2.3.2 Sample Handling. This section should list the information that will be logged in specific to daily operations (e.g., samples handled, standards used, QC samples prepared, procedures used, and resultant calculations).

C.9.2.3.3 Instrument Operation. This section should list the information that will be included in the logbook for each instrument (e.g., date, operator, description of maintenance, instrument settings, samples analyzed). This section should also list all the information that should be put on hard copy data outputs from instrument printouts.

\section{C.10 AUDITS}

This section discusses performance and system audits for evaluating the performance and quality of project field and laboratory operations.

\section{C.10.1 Field System Audits}

A field audit should be performed during the first few days of the initiation of field activities by the QA manager (or designee) to determine if the field teams are following protocols delineated in the QAPP. This section should contain a listing of the items that the QA manager will check for performance (e.g., copies of all appropriate plans and forms, required instruments [properly calibrated], logbooks, sample collection procedures, and packaging of samples). This section will also include a brief discussion of what the QA manager's actions would be if deficiencies were encountered and where results of the audit will be maintained.

\section{C.10.2 Laboratory System Audits}

This section should list items that would be monitored during laboratory audits (e.g., description of the laboratory, information on instrumentation, adherence to SOPs, staff qualifications and training, storage facilities, logbooks). This section should also discuss the evidentiary audit that would be required for the project. This audit includes a procedural audit, a written SOP audit, and an analytical project file evidence audit. This audit is conducted to determine if laboratory policies and procedures are in place. 


\section{C.10.3 Performance Audits}

This section should discuss how the EPA would submit a spiked performance evaluation blank sample(s) to the laboratory for analysis and that the results would be used by the EPA to determine the accuracy of the laboratory.

\section{C.11 CORRECTIVE ACTION}

This section should describe how and when corrective actions wculd be initiated (e.g., due to deficiencies encountered during audits or failure to adhere to QAPP requirements). Mention should be made as to at what managerial level corrective actions would be made and what action would be taken if problems could not be resolved. The steps in taking corrective actions should be listed, starting with identification of the problem and ending with verification that the problem has been corrected. A copy of a corrective action report form can be included in this section to show how the corrective action process would be documented.

\section{C.12 QUALITY CONTROL REPORTS}

This section should list all the documents and deliverables that would be submitted to DOE in support of the project work conducted at the site (e.g., certification packages, audit reports, QC status reports, logbooks).

\section{C.13 REFERENCES}

This section should list complete citations for all references called out in the text. 
APPENDIX D:

SENSITIVE ENVIRONMENTS RATING VALUES 


\section{APPENDIX D: \\ SENSITIVE ENVIRONMENTS RATING VALUES}

This appendix lists sensitive environments and scoring values used by the U.S. Environmental Protection Agency in the hazard ranking system of those sites under consideration for being placed on the National Priorities List (40 CFR Part 300, Appendix A). In evaluating the potential impacts of U.S. Department of Energy (DOE) Comprehensive Environmental Response, Compensation, and Liability Act (CERCLA) sites, adjacent sites as well as on-site areas must be evaluated. The types of environments listed in the following table (taken from 55 Federal Register 51582, December 14, 1990, as revised on October 1, 1991, p. 3-157) should be considered by ecologists and the DOE Remedial Project Manager in developing a list of habitats requiring ecological data collection in cases where sensitive environments are likely to be impacted by hazardous contaminants (see Module 9 of the guidance document). The numerical value given could be useful to indicate the relative importance of the sensitive environment present in the vicinity of the CERCLA site. 
TABLE D.1 Sensitive Environments Rating Values

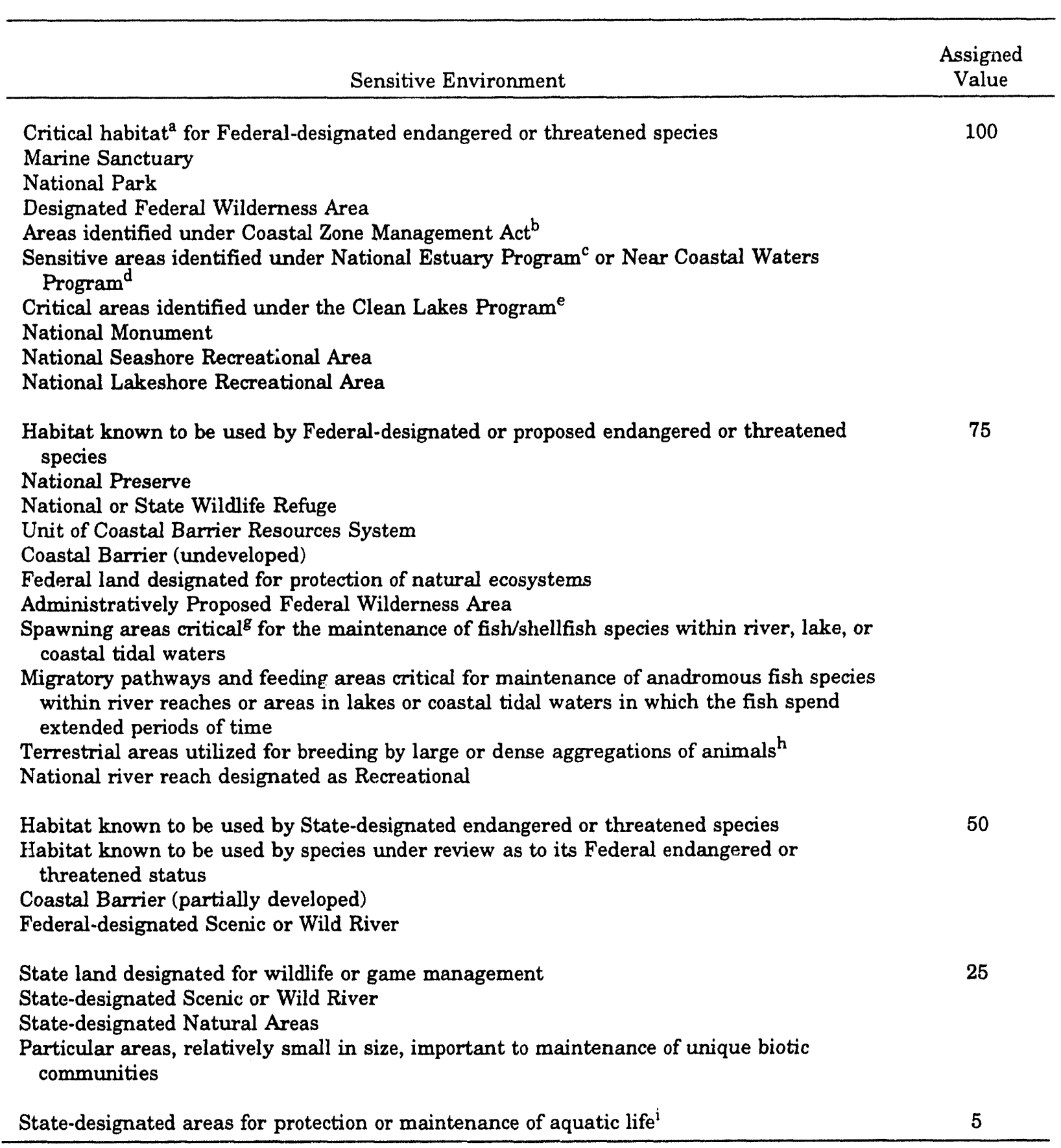

See next page for footnotes. 
a Critical habitat as defined in 50 CFR 424.02 .

b Areas identified in State Coastal Zone Management plans as requiring protection because of ecological value.

c National Estuary Program study areas (subareas within estuaries) identified in Comprehensive Conservation and Management Plans as requiring protection because they support critical life stages of key estuarine species (Section 320 of Clean Water Act, as amended).

d Near Coastal Waters as defined in Sections 104(b)(3),304(1), 319, and 320 of Clean Water Act, as amended.

e Clean Lakes Program critical areas (subareas within lakes, or in some cases entire small lakes) identified by State Clean Lake Plans as critical habitat (Section 314 of Clean Water Act, as amended).

f Use only for air migration pathway.

g Limit to areas described as being used for intense or concentrated spawning by a given species.

h For the air migration pathway, limit to terrestrial vertebrate species. For the surface water migration pathway, limit to terrestrial vertebrate species with aquatic or semiaquatic foraging habits.

i Areas designated under Section 305(a) of Clean Water Act, as amended. 


\section{APPENDIX E: \\ U.S. ENVIRONMENTAL PROTECTION AGENCY REGIONAL BIOLOGICAL TECHNICAL ASSISTANCE GROUP COORDINATORS/CONTACTS}




\section{EPA HEADQUARTERS}

Ruth Bleyler

Toxics Integration Branch (OS-230)

OERR/HSED

USEPA

Washington, DC 20460

(703) 603-8816

(703) 603-9104 FAX

David Charters

ERT

USEPA (MS-101)

2890 Woodbridge Ave.,

Bldg. 18

Edison, NJ 08837-3679

(908) 906-6826

(908) 906-6724 FAX

Steve Ells

Elaine Suriano

OWPE

USEPA (OS-510)

401 M Street S.W.

Washingtor, DC 20460

(202) 260-9803

(202) 260-3106 FAX

Joseph Tieger

USEPA (OS-510W)

401 M Street S.W.

Washington, DC 20460

(202) 308-2668

\section{REGION 1}

Susan Svirsky

Waste Management Division

USEPA Region 1 (HSS-CAN7)

JFK Federal Building

Boston, MA 02203

(617) 573-9649

(6170 573-9662 FAX

\section{REGION 2}

Sharri Stevens

Surveillance Monitoring Branch

USEPA Region 2 (MS-220)

Woodbridge Avenue

Raritan Depot Building 209

Edison, NJ 08837

(908) 906-6994

(909) 321-6616 FAX

\section{REGION 3}

Robert Davis

Technical Support Section

USEPA Region 3 (3HW13)

841 Chestnut Street

Philadelphia, PA 19107

(215) 597-3155

(215) 597-9890 FAX

\section{REGION 4}

Lynn Wellman

WSMD/HERAS

USEPA Region 4

345 Courtland Street, NE

Atlanta, GA 30365

(404) 347-1586

(404) 347-0076 FAX

\section{REGION 5}

Eileen Helmer

USEPA Region 5

(5HSM-TUB7)

230 South Dearborn

Chicago, IL 60604-1602

(312) 886-4828

(312) $886-7160 \mathrm{FAX}$

\section{REGION 6}

Jon Rauscher

Susan Swenson Roddy

USEPA Region 6 (6H-SR)

First Interstate Tower

1445 Ross Avenue

Dallas, TX 75202-2733

(214) 655-8513

(214) 655-6762 FAX

\section{REGION 7}

Bob Koke

SPFD-REML

USEPA Region 7

726 Minnesota Avenue

Kansas City, KS 66101

(913) 551-7468

(913) 551-7063 FAX

\section{REGION 8}

Gerry Henningsen

USEPA Region 8

Denver Place, Suite 500

$99918^{\text {th }}$ Street

Denver, CO 80202-24-5

(303) 294-7656

(303) 293-1230 FAX

\section{REGION 9}

Doug Steele

USEPA Region 9

75 Hawthorne Street

San Francisco, CA 94105

(415) 744-2309

(415) 744-1916 FAX

\section{REGION 10}

Bruce Duncan

USEPA Region 10 (ES-098)

$12006^{\text {th }}$ Avenue

Seattle, WA 98101

(206) 553-8086

(206) 553-0119 FAX 
APPENDIX F:

GLOSSARY 


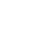




\section{APPENDIX F:}

\section{GLOSSARY}

assessment endpoint: Formal expressions of the actual environmental values to be protected.

baseline risk assessment: Identification of risks associated with taking no action at a CERCLA site.

bioaccumulation: The net accumulation of a chemical by an organism as a result of uptake from all exposure routes.

bioconcentration: Tendency for a chemical to occur in biota at higher concentrations than in the surrounding environmental medium; used mostly in the context of aquatic organisms in aquatic media.

biomagnification: The tendency of some chemicals to accumulate to higher concentrations at higher levels in the food web through dietary accumulation.

biomarker: Measurement of body fluids, cells, or tissues that indicate, in biochemical or cellular terms, the presence and magnitude of toxicants or host response.

dose: A measure of exposure per unit time.

ecological assessment work plan: A document that identifies the ecological risk assessment process to be conducted at a CERCLA site.

ecological risk assessment: The process of evaluating the likelihood that adverse ecological effects may occur or are occurring as a result of exposure to one or more stressors.

effects: Changes in biotic parameter values specified by the assessment endpoints that are potentially attributable to a pollutant.

endpoint: A characteristic of an ecological component that may be affected by exposure to a stressor.

feasibility study: A study undertaken by a lead federal agency to develop and evaluate options for remedial action.

field sampling plan: Description of sampling and data collection methods necessary to conduct an ecological assessment.

measurement endpoint: Quantitative expressions of an observed or measured effect of a hazard that must correspond to or predict assessment endpoints.

quality assurance project plan: A written document that describes the organization, objectives, functional activities, and specific quality assurance and quality control procedures designed to achieve data quality objectives for a CERCLA project. 
reference area: A relatively unpolluted site having essentially the same ecological and physical properties used for comparison to the polluted site being evaluated.

remedial action: Those actions taken at a CERCLA site consistent with the selected permanent remedy to prevent or minimize the release of a hazardous substances into the environment so that substance migration does not cause substantial danger to present or future public health or welfare or the environment.

remedial investigation: The process undertaken by the lead federal agency at a CERCLA site to determine the nature and extent of the problem presented by the release.

stressor: A chemical, radiological, or physical hazard at or near a contaminated site that can adversely effect resident or transient species.

toxicity: The harmful effects resulting from exposure to a pollutant; chemical properties that cause harmful effects in organisms. 

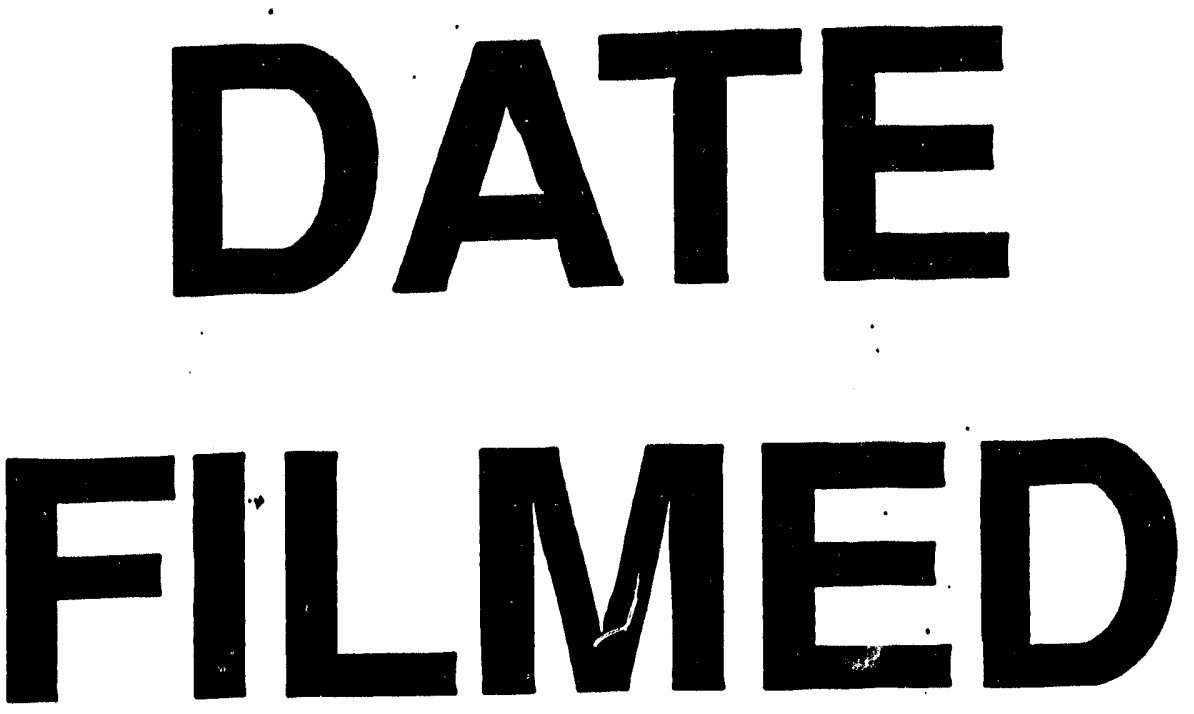

$1 / 20 / 94$
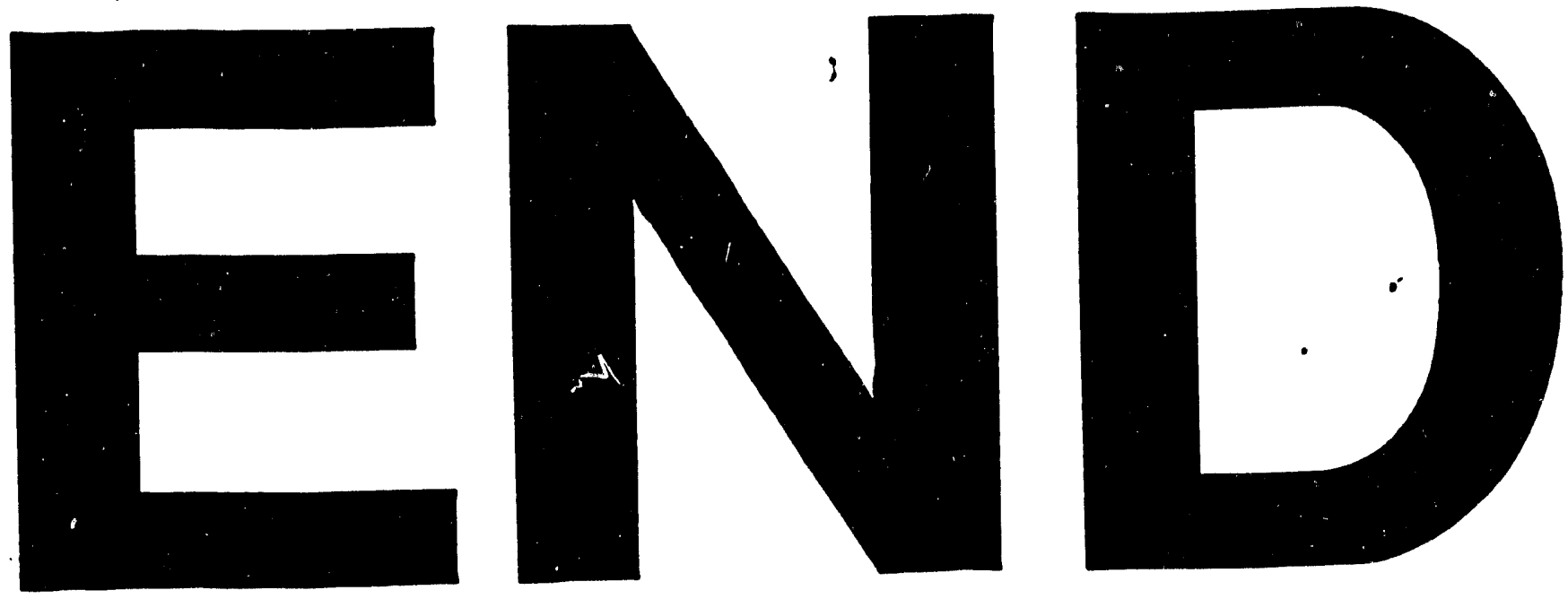
